UNIVERSIDADE DE SÃO PAULO

FACULDADE DE EDUCAÇÃO

NATÁLIA FERRARINI GIOPATO

AS FONTES GRECO-ROMANAS NO PENSAMENTO

POLÍTICO-PEDAGÓGICO DE ROUSSEAU

SÃO PAULO

2018 
NATÁLIA FERRARINI GIOPATO

\title{
AS FONTES GRECO-ROMANAS NO PENSAMENTO POLÍTICO-PEDAGÓGICO DE ROUSSEAU
}

\author{
Dissertação apresentada à \\ Faculdade de Educação da \\ Universidade de São Paulo \\ para obtenção do título de \\ Mestre em Educação.
}

Área de Concentração:

Filosofia e Educação

Orientadora: Profa. Dra.

Maria de Fátima Simões Francisco

Versão corrigida

(Versão original encontra-se na Biblioteca da Unidade que aloja o Programa de Pós-Graduação) 
AUTORIZO A REPRODUÇÃO E DIVULGAÇÃO TOTAL OU PARCIAL DESTE TRABALHO, POR QUALQUER MEIO CONVENCIONAL OU ELETRÔNICO, PARA FINS DE ESTUDO E PESQUISA, DESDE QUE CITADA A FONTE.

Catalogação na Publicação

Serviço de Biblioteca e Documentação

Faculdade de Educação da Universidade de São Paulo

$37.01 \quad$ Giopato, Natália Ferrarini

G496f As fontes greco-romanas no pensamento político-pedagógico de Rousseau / Natália Ferrarini Giopato; orientação Maria de Fátima Simões Francisco. São Paulo: s.n., 2018.

$126 \mathrm{p}$.

Dissertação (Mestrado - Programa de Pós-Graduação em Educação. Área de Concentração: Filosofia e Educação) - - Faculdade de Educação da Universidade de São Paulo.

Versão corrigida

1. Rousseau, Jean-Jacques, 1712-1778 2. Cidadania 3. Educação 4. Roma 5. Esparta 6. Antiguidade I. Francisco, Maria de Fátima Simões, orient.

Elaborado por Nicolly Leite - CRB-8/8204 
Nome: GIOPATO, Natália Ferrarini

Título: As fontes greco-romanas no pensamento político-pedagógico de Rousseau

Dissertação apresentada à Faculdade de Educação da Universidade de São Paulo para obtenção do título de Mestre em Educação.

Aprovada em:

\section{Banca Examinadora}

Prof (a). Dr (a).

Instituição:

Julgamento:

Prof (a). Dr (a).

Instituição:

Julgamento:

Prof (a). Dr (a).

Instituição:

Julgamento 
À minha família:

Nádia, José Carlos e Camila. 


\section{AGRADECIMENTOS}

A tarefa de contemplar, em algumas linhas, todos aqueles que colaboraram para a tessitura desta dissertação é árdua, para não dizer inviável. Refiro-me não apenas aos familiares e amigos, mas aqueles que participaram de alguma forma da minha trajetória e deixaram sua marca na memória. Dito isso e, desde já me desculpando por possíveis omissões, gostaria de agradecer:

À Faculdade de Educação da Universidade de São Paulo (FEUSP), instituição da qual me orgulho, pela formação recebida.

À minha orientadora Profa. Dra. Maria de Fátima Simões Francisco, a quem sou profundamente grata pelas aulas ministradas sobre Rousseau e pela oportunidade de desenvolver esta pesquisa.

A todos os mestres que se tornaram exemplos para a minha carreira como docente.

A todas as colegas de trabalho, professoras e profissionais da Educação, que contribuíram de algum modo para o meu aprimoramento profissional.

Aos alunos que passaram pela minha vida e aos que ainda estão presentes, que marcaram e irão marcar meus passos futuros; agradeço por conferirem à cada iniciativa acadêmica e profissional todo o sentido que poderia atribuir.

Ao Renato, por alegrar inúmeros momentos da minha vida com sua admiração, amizade, carinho e bom humor.

À Thayná, confidente, sempre mais que prima. Apesar dos afastamentos esporádicos que por vezes acontecem, sua presença me cerca de segurança e amor.

Aos meus pais, Nádia e José Carlos, seres humanos exemplares, que me amam incondicionalmente, a quem dedico essa dissertação. Fontes de inspiração e fortaleza.

À Camila, companheira, a quem também dedico este trabalho. Por toda a parceria, presente em momentos de angústia e felicidade, com quem tenho o prazer de compartilhar meus dias. 
À Assumpta, avó amada, agradeço por seu amor, por continuar presente e me fortalecendo nos momentos de dificuldade.

A Dom Bosco, por seu legado espiritual. 
RESUMO

GIOPATO, Natália Ferrarini. As fontes greco-romanas no pensamento políticopedagógico de Rousseau. 2018. 126 f. Dissertação (Mestrado em Educação) Faculdade de Educação, Universidade de São Paulo, São Paulo, 2018.

O objetivo deste trabalho é investigar os referenciais clássicos como parâmetros fundamentais no desenvolvimento da teoria de Rousseau, e como o autor analisava as sociedades modernas respaldado nessas fontes, orientando-se na elaboração de sua crítica social. As inúmeras referências à Antiguidade greco-romana, em suas obras, não apenas testemunham uma vinculação e apropriação muito particulares a esses temas, mas demonstram um enaltecimento ao ideal de cidadania vivido pelos espartanos e romanos. Isso posto, propõe-se compreender o lugar da Educação no entendimento da relevância desses parâmetros clássicos para a constituição da teoria rousseauniana, especificamente, no que diz respeito ao arquétipo de cidadania. Nas cidades-modelo de Rousseau, todo o ambiente fomentava a formação do almejado cidadão: não se tratava de uma proposta específica de educação aqui ou acolá, mas de uma arquitetura política a partir da qual crianças e jovens eram engendrados no seio de sua pátria a se constituírem cidadãos na e pela vida em comunidade. A partir desse raciocínio, pretende-se resgatar parte significativa do pensamento de Rousseau, alicerçada no legado greco-romano, mais especificamente, sobre a Esparta clássica e Roma republicana, como recursos para adentrar nos fundamentos político-educacionais dessas sociedades e entender o impacto desse legado na constituição da filosofia e da pedagogia de Rousseau, associadas às ideias de identidade nacional e virtude cívica. A finalidade deste estudo, portanto, é investigar a adesão do genebrino a esses exemplos históricos verificando se, de fato, há um alicerce primordial do âmbito político-formativo das suas cidades-modelo a partir do qual o autor se pautaria.

Palavras-chave: Rousseau. Cidadania. Educação. Roma. Esparta. Antiguidade clássica. 


\begin{abstract}
GIOPATO, Natália Ferrarini. The Greco-Roman sources in the politicalpedagogical thought of Rousseau. 2018. 133 f. Dissertação (Mestrado em Educação) - Faculdade de Educação, Universidade de São Paulo, São Paulo, 2018.
\end{abstract}

The objective of this work is to investigate the classical references as fundamental parameters in the development of Rousseau's theory, and how the author analyzed the modern societies based in these sources, orienting himself in the elaboration of his social criticism. The innumerable mentions to the Greco-Roman antiquity, in his studies, testify a particular connection and appropriation to this themes and it shows an appreciation by the ideal of citizenship that characterize the Spartans and Romans. In view of this, it is proposed to understand the place of Education to understand the relevance of these classic parameters to the constitution of Rousseau's theory, specifically, the archetype of citizenship. In the Rousseau's model cities, all the ambience fostered the formation of the citizen: it was not a specific proposal of education, here or there, but a political architecture from which children and young people were engendered in the bosom of their homeland to become citizens in and for the life in community. From this reasoning, it is intended to rescue a significant part of Rousseau's thought, based on the Greco-Roman legacy, more specifically, about classical Sparta and republican Rome, as resources to enter the political-educational foundations of these societies and to understand the impact of this legacy in the constitution of Rousseau's philosophy and pedagogy, associated to the ideas of national identity and civic virtue. Therefore, the purpose of this study is to investigate the adhesion of the studious to these historical examples, verifying if, in fact, there is a primordial foundation of the political-formative scope of his model cities from which the author would be based.

Keywords: Rousseau. Citizenship. Education. Rome. Sparta. Classical antiquity. 
PARTE I: TRAÇOS BIOGRÁFICOS DE ROUSSEAU E AS FONTES GRECO-ROMANAS

1 JEAN-JACQUES ROUSSEAU: BREVE BIOGRAFIA …........................... 15

2 ESPARTA CLÁSSICA E A FORMAÇÃO DO GUERREIRO ...................... 21

3 A REPÚBLICA ROMANA E A FORMAÇÃO PARA A LIBERDADE ............ 34

3.1 A função formativa do censor romano ........................................ 56

PARTE II: ROUSSEAU E O REPUBLICANISMO

4 ORIGENS DO REPUBLICANISMO: O CAMINHO ATÉ A REVOLUÇÃO

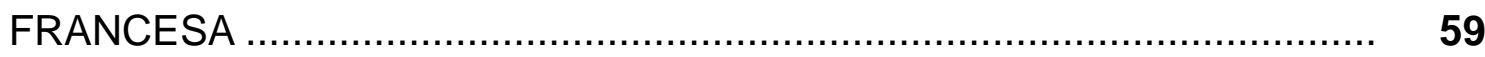

4.1 Enciclopédia e a formação do léxico republicano …….................. 75

5 O CONTEXTO PÓS-REVOLUÇÃO FRENTE AO LEGADO DE ROUSSEAU 79

PARTE III: EDUCAÇÃO PARA A CIDADANIA

6 EMÍLIO E O DILEMA DE FORMAÇÃO: FORMAR O HOMEM OU O

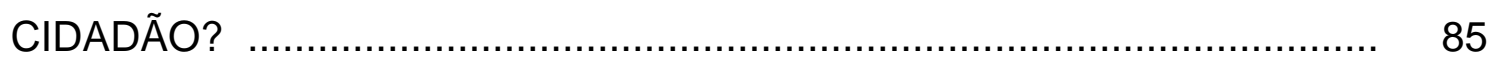

7 CONSIDERAÇÕES SOBRE O GOVERNO DA POLÔNIA: UMA COMPOSIÇÃO REPRESENTATIVA DA LEITURA ROUSSEAUNIANA DE REPÚBLICA E

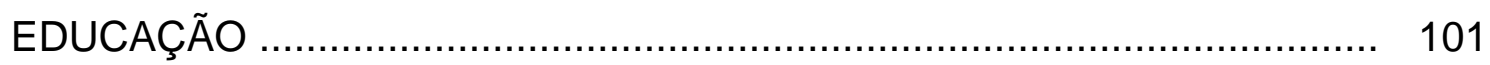

8 EDUCAÇÃO PARA A CIDADANIA: A FORMAÇÃO DA ALMA NACIONAL 108

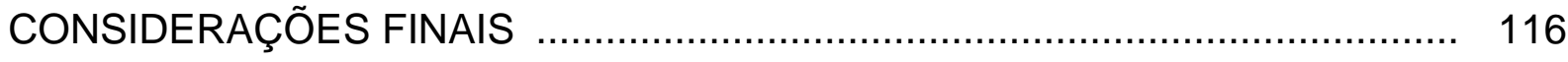

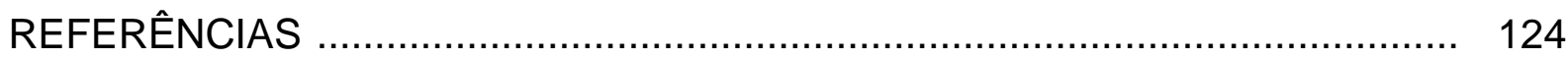




\section{INTRODUÇÃO}

Jean-Jacques Rousseau, como outros renomados teóricos, fez do estudo da natureza do homem uma estratégia para investigá-lo, em sociedade, com seus desvirtuamentos ao longo da História. Suas inúmeras referências à antiguidade greco-romana, em suas obras, não apenas testemunham uma vinculação afetivoteórica, como veremos em sua breve biografia, mas demonstram um enaltecimento ao ideal de cidadania vivido pelos espartanos e romanos da Antiguidade. O modo como Rousseau entende a natureza humana parece indicar um olhar constituído paulatinamente a partir dos referenciais clássicos os quais acessou desde criança. Procuraremos precisar como tais parâmetros tornaram-se fundamentais no desenvolvimento de sua crítica social e o modo como analisava as sociedades modernas, orientando-o na elaboração de sua Filosofia. Qual seria, então, o lugar da Educação no entendimento da relevância desses parâmetros clássicos para a constituição da teoria rousseauniana, especificamente, no que diz respeito ao ideal de cidadania? Nas cidades-modelo de Rousseau, todo o ambiente fomentava a formação do almejado cidadão: não se tratava de uma proposta específica de educação aqui ou acolá, mas de uma arquitetura política a partir da qual crianças e jovens eram engendrados no seio de sua pátria a constituírem-se cidadãos na e pela vida em comunidade.

O autor, em questão, parte de uma abstração ou meditação (ROUSSEAU, 2008) para desenvolver sua teoria da história do homem. Tal abstração, de modo simplificado, considera o homem no que seria seu primeiro estado, o estado de natureza, guiado sobretudo pelo instinto de autopreservação e por sensações associadas como medo, fome, desejo sexual, entre outras. Esse homem, por sua vez, possui um diferencial, qual seja, ser livre para seguir ou não os comandos da natureza. A liberdade no estado de natureza, vinculada à autopreservação, seria o elemento que o estimularia a viver em comunidade, após compreender os benefícios da associação aliada à fragilidade em que se encontrava quando isolado'. No

\footnotetext{
${ }_{1}^{1}$ Para se livrar de uma ameaça, como a de um animal selvagem ou para caçar, o homem, no estado de natureza, poderia associar-se a outros temporariamente para satisfazer essas necessidades de sobrevivência, segundo prescreve Rousseau.
} 
entanto, o progresso da vida em sociedade, sobretudo com a divisão da propriedade, teria levado as gerações humanas à desigualdade social advinda da acumulação de bens de poucos em prejuízo de muitos.

Tal abstração ${ }^{2}$ é um ponto significativo para o desenvolvimento da presente dissertação, considerando ser ela a articulação chave para o entendimento da forma que o autor se servia para o desenvolvimento de sua teoria político-pedagógica, assim como a ideia de natureza humana, perfectibilidade e corrupção social.

A partir desse raciocínio, pretende-se resgatar parte significativa do pensamento de Rousseau, alicerçada no legado greco-romano, mais especificamente sobre a Esparta clássica e Roma republicana, como recursos para adentrar nos fundamentos político-educacionais dessas sociedades e entender o impacto desse legado na constituição da filosofia e da pedagogia de Rousseau.

Para fundamentar esse impacto formativo, serão utilizadas como obras representativas do filósofo, sobretudo, Considerações sobre o governo da Polônia e sua projetada reforma, a qual ilustra a formação do cidadão pensado por Rousseau, educado para amar a pátria, bem como o Contrato Social. Emílio e o Discurso sobre as Ciências e as Artes, adicionalmente, são obras nas quais podem ser identificadas referências aos modelos da Antiguidade, escolhidos por Rousseau e outras características que dialogam com as obras aqui citadas. Esses escritos, entre outros, permitem paralelos de observação sobre como as fontes greco-romanas apresentam-se como constantes nos seus elementos teóricos. A seguir, estarão dispostos alguns tópicos que, de forma sintética, traçam possibilidades de estudo e produção de modo a contemplar a análise referida nesses parágrafos introdutórios.

De modo a qualificar e fomentar essa discussão teórica, destacam-se quatro obras principais que ajudaram a nortear o que se pretendeu desenvolver a respeito da influência da Antiguidade Clássica e ramificações teóricas correlatas: JeanJacques Rousseau et le mythe de l'Antiguité, de Denise Leduc-Fayette; As aventuras da virtude: as ideias republicanas na França do século XVIII; História da Educação na Antiguidade, de Henri-Irénée Marrou e Jean-Jacques Rousseau: a face arcaica do cidadão, de Fábio de Barros Silva. É importante destacar que, sem a contribuição

\footnotetext{
2 "Rousseau: O Bom Selvagem", de Salinas Fortes (1989), é um estudo complementar de excelente valia no que diz respeito à compreensão da temática do estado de natureza e processo posterior, onde se pode encontrar um aprofundamento teórico nos capítulos "Sociedade versus natureza" e "As peripécias da desigualdade".
} 
de outros textos referenciados ao longo do trabalho, essa dissertação não seria viável.

A partir dessa realidade, cabe resgatar as origens da fundação e dos princípios republicanos, princípios esses presentes nos escritos do genebrino, a partir do seu respaldo teórico embasado nas fontes greco-romanas, valorizados por ele e aproveitados de modo exemplar em suas obras citadas anteriormente. Tais referenciais serviram de base para a democracia da sociedade ocidental, e podem ser pensados como caminhos elucidativos para a compreensão do legado do filósofo. Considerações é, no presente trabalho, entendida como obra pensada simbolicamente por Rousseau para representar sua compreensão de alma nacional, em uma época de decadência do Antigo Regime, da sociedade de classes e da efervescência cultural iluminista, aliada a uma conquista progressiva de espaço pela burguesia ascendente.

Rousseau traçava um Contrato entre um indivíduo que, percebendo em dado momento a vulnerabilidade de seu estado de natureza e afastamento de outros da espécie, deixava essa condição para se tornar membro de uma comunidade, e, posteriormente, do corpo civil, com a promessa estatal que, contribuindo para a manutenção dessa união, teria a sua proteção assegurada pelo Estado. O princípio contratualista funda, por esse raciocínio, a obrigação política moderna e os aspectos essenciais das Constituições ocidentais conhecidas, deixando-nos, hoje, questionamentos acerca do seu real cumprimento e legitimidade.

Isso posto, objetivamos, nesta pesquisa, dissertar a respeito dos princípios republicanos originários do legado greco-romano (entendidos como alicerces democráticos da sociedade ocidental), pautados nas ideias de identidade nacional e virtude cívica apropriadas por Rousseau. No desenvolvimento dessas obras, é possível acompanhar a importância formativa da República, e, por isso, o retorno a ela, especificamente aos modelos de Esparta Clássica e Roma republicana, constitui, também, um objetivo, vinculada à função indispensável da figura dos governantes e educadores na medida em que se atribui à figura dos mais velhos e à tradição o papel de referenciais de lucidez histórica e respaldo educacional.

A presente dissertação está dividida em três partes vinculadas pela temática central do arquétipo de cidadania, cada uma apresentando capítulos com um potencial dialógico mais direto entre si. A primeira parte contém três capítulos e um subcapítulo, a segunda parte; dois capítulos, sendo que a última inclui três. $\mathrm{Na}$ 
primeira parte, nomeada Traços biográficos de Rousseau e a fontes greco-romanas, observaremos como as linhas biográficas de Rousseau o encaminharam para o estudo e leitura que faz do legado greco-romano. De modo a possibilitar um maior entendimento dos cenários governamentais que o encantaram, percorreremos os recortes históricos de Esparta Clássica e Roma republicana, caracterizando-as e procurando compreender o uso próprio que Rousseau faz delas, deslocando-se da realidade para o mito e à crítica social retornando como recurso metodológico, para fundamentar seus ideais políticos e educacionais. Veremos os motivos pelos quais se tornaram cidades-modelo para o genebrino que enalteciam, muito entre outras razões, a vida política, comunitária e pública que cultivavam, formando suas crianças e jovens para a preservação do bem público e do legado cultural existente, cada qual com suas particularidades.

Na segunda parte, Rousseau e o Republicanismo, trataremos, no primeiro capítulo, de modo sintético do contexto revolucionário do século XVIII francês, com o objetivo de compreender o léxico republicano formado anteriormente a esse período, constituindo o terreno que prepararia os teóricos da "época das Luzes". Desse modo, reforçaremos como esse arcabouço linguístico foi anterior à Revolução Francesa, e como chegou até Rousseau, traçando caminhos percorridos e apropriações históricas da Antiguidade até a modernidade, com a intenção de compreender o apelo teórico moderno aos valores antigos, e como tal recurso se justifica especificamente no legado de Rousseau. No subcapítulo sobre a Enciclopédia, disponibilizaremos algumas linhas a respeito do projeto editorial mais ambicioso e influente dos pensadores da época, representando eixo fundamental do processo de criação de uma nova linguagem para se pensar o mundo e que veio a colaborar com a constituição do republicanismo francês. A Enciclopédia é apresentada como ferramenta permeada de críticas ao Antigo Regime e aos percalços a ele subjacentes, críticas estas que, em muitos aspectos, dialogam com o posicionamento teórico-político de Rousseau. No segundo capítulo, será apresentado o contexto pós-revolução frente ao legado do genebrino, explicitando o status quo em que a sociedade francesa encontrava-se diante desse novo cenário político, e o lugar do Círculo Social e do jornal Boche de fer, os quais pretendiam exercer a função de porta voz do povo oprimido e guia conceitual da população, embasados, sobretudo, nos ideais advindos do Contrato Social. 
$\mathrm{Na}$ terceira e última parte, Educação para a cidadania, iniciamos com Emílio e o dilema de formação: formar o homem ou o cidadão, capítulo dedicado a discorrer sobre a ideia de "concerto" entre o homem natural e o ser social, analisando referências teóricas que desenvolvem paralelos entre o menino Emílio como um "tipo ideal" e o homem em seu estado de natureza, discutindo possibilidades a respeito da formação para a cidadania, na supracitada obra. Diante da ideia rousseauniana mais difundida, qual seja, o homem nasce naturalmente bom, mas a sociedade o corrompe, pondera-se a respeito da possibilidade de uma reconfiguração da vida em sociedade, em que o homem possa aperfeiçoar-se resgatando e adaptando os sentimentos naturais nele existentes.

No sétimo capitulo, referente a Considerações sobre o governo da Polônia, identificamos nessa obra de Rousseau uma composição que representa uma leitura do autor de República e Educação, permeada de sentidos apropriados pelo genebrino, na qual ele, mais uma vez, retorna aos referenciais antigos como estratégia para ilustrar e reforçar seus princípios político-educacionais. Em muitos aspectos das instituições e do governo delineados e idealizados por Rousseau, assumidos como instituições formativas, que promovem o cidadão, são percebidas as raízes clássicas do genebrino. Algumas passagens do livro, por exemplo, são claramente associadas aos referenciais antigos. No último capítulo, sobre formar a alma nacional, procuraremos evidenciar a centralidade da formação do cidadão na obra de Rousseau, centralidade esta que justifica os pilares greco-romanos que acompanharam o genebrino no desenvolvimento de sua Filosofia.

Ao final da dissertação, temos como objetivo revisitar todo o caminho teórico percorrido no presente trabalho, de modo a promover uma análise dialógica entre as partes desta composição para averiguar - e esse é um dos principais objetivos aqui colocados - se, de fato, a adesão do genebrino a esses exemplos históricos deve-se ao que o filósofo vislumbrava como essencial que, para nós, trata-se do valor imprescindível do âmbito político-formativo das suas cidades-modelo. Em outras palavras, verificar se uma República, para o genebrino, só é possível se for genuinamente formativa, desenvolvendo com a Educação uma relação basilar e simbiótica. 


\title{
PARTE I: TRAÇOS BIOGRÁFICOS DE ROUSSEAU E AS FONTES GRECO-ROMANAS
}

\section{JEAN-JACQUES ROUSSEAU: BREVE BIOGRAFIA}

Nascido a 28 de junho de 1712, em Genebra, Jean-Jacques Rousseau tornou-se um influente filósofo e reconhecido teórico político. Sua relação com o lluminismo foi intensa e paradoxal.

\begin{abstract}
Cidadão de Genebra, interlocutor e provocador de Voltaire em Paris, hóspede de Hume na Inglaterra, pomo de discórdia de grandes polêmicas, Rousseau transformou-se em polo desafiador à lucidez do processo de valorização da razão. Pode-se reconhecer em Rousseau ao mesmo tempo um crítico da tradição filosófica e pedagógica e também um crítico das novas Luzes com sua idealização da razão, sendo que, nesse sentido, Rousseau fez avançar o lluminismo por sua própria crítica. (ALBORNOZ, 2006, p. 74).
\end{abstract}

Destrinchando a vida do filósofo, Nicholas Dent (1996) comenta relevantes recortes de sua história, apresentando-o como segundo filho do relojoeiro Isaac Rousseau (homem de razoável formação e marcantes interesses literários) e batizado na Igreja Calvinista, tendo, precocemente, perdido sua mãe, Suzanne Bernard, dois dias após tal cerimônia. Quando criança apreciava, em companhia de seu pai, longas e distintas leituras, nas quais se sobressaiam os escritos de Plutarco. Após a morte da mãe, a situação financeira declinou, consideravelmente, e a família mudou-se para um bairro mais pobre.

Segundo Leduc-Fayette (1974), Rousseau, desde sua infância, debruçou-se sobre a obra de Plutarco, Vidas Paralelas, entusiasmando-se com as suas fábulas heroicas. Como alguém que sonha como um aprendiz e pretende safar-se de sua atual condição, tentando transitar de aprendiz para mestre, o genebrino apropria-se dessas figuras exemplares. Face a essa influência, Rousseau vislumbrava, nesses exemplos, a possiblidade de se tornar um homem ilustre, por e apesar de identificar, em si mesmo, inúmeras limitações, resgata a autora nas Confissões. Identificação e admiração foram elementos fundamentais na construção do arquétipo que Rousseau formou a partir dos referenciais clássicos.

Aos dez anos, logo após o novo casamento do pai, Rousseau foi entregue a um tio, que o encaminhou com seu primo Abraham para residir na casa do pastor Lambercier, vivendo lá anos harmoniosos e estáveis. Em 1725, tornou-se aprendiz 
de Ducommun, um gravador que o acolheu em sua iniciação e que the gerou momentos de intensa insatisfação, por sua crueldade e implacabilidade, conforme o filósofo relataria nas suas Confissões anos depois. De sua parte, Rousseau também explicita que não era dedicado aprendiz e dispunha de poucas habilidades concernentes ao ofício. Três anos depois, deixa Genebra e, após perambular pela cidade, encontra ajuda junto a um sacerdote católico que o recomenda à baronesa de Warens, em Annecy, com indicativo de pretensão ao sacerdócio. Recémconvertida, ajudava a recrutar e manter possíveis neófitos católicos. O encontro entre ambos foi decisivo: os dois ficaram interligados por doze anos seguidos, em uma relação em que para ele a baronesa era sua maman, ao passo que ela o via como seu petit.

Inicialmente, o genebrino foi enviado a Turim para instruir-se e preparar-se para o sacerdócio, mas alguns reveses - incluindo sua pouca inclinação ao intento fizeram com que encontrasse lugar como lacaio na casa da condessa de Vercellis. Com esse contato, pôde conhecer o abade Gaime, cujas meditações partilhadas o influenciaram fortemente. Após a morte da condessa, em 1728, não demorou muito para que começasse a trabalhar como secretário do abade Gouvon, mas, por conta do seu pouco empenho nas tarefas exigidas, foi demitido em 1729. Após algumas aventuras, Rousseau retorna à casa da baronesa de Warens, onde seu plano para o sacerdócio é novamente delineado pela senhora, tendo estudado com outro abade, Gâtier, figura que, também, influiu profundamente no pensamento religioso do genebrino. O vigário saboiano, personagem presente no Livro IV do Emílio indicam, em grande medida, um misto das ideias de Gaime e Gâtier, como atribui Nicholas Dent (1996), em sua análise da vida e obra de Rousseau. Não revelando habilidades para a vida religiosa, Rousseau passa a interessar-se por música, tendo ingressado em uma schola cantorum. Segue-se um tempo instável de cerca de um ano e meio, durante o qual ele ganha alguma quantia lecionando música e copiando partituras. Ao término desse período, regressa e permanece com quase completa continuidade ao lado da senhora Warens, a baronesa, com suas aulas de música, organizações de serões, leituras constantes e auxílios à sua benfeitora em seus diferentes projetos.

Ao completar 21 anos, Rousseau tem, em seu lar, uma confusa e triste mudança: a senhora Warens resolve iniciá-lo sexualmente. Esse descaminho tornase ainda mais complexo devido à presença de Claude Anet, mordomo e também amante da baronesa. Pouco tempo depois, Anet morre em circunstâncias 
questionáveis, o que fez Rousseau assumir-se mais continuamente como amante e administrador dos assuntos domésticos.

Apesar dessa situação, os escritos do filósofo parecem indicar que os dois anos subsequentes foram especialmente agradáveis e profícuos, proporcionando-Ihe contínuo prazer, na medida em que pode intensificar suas leituras. Em 1738, Rousseau teve sua relação com a senhora Warens bastante alterada e fragilizada, circunstância desencadeada pelo ingresso de um auxiliar e amante, Wintzenried, na vida da baronesa. Por isso, mudou- se para Lyon, logo depois, para se tornar preceptor dos filhos de um prestigiado aristocrata. Com essa experiência, inicia-se uma importante fase para o genebrino que, embora não fosse muito eficiente e tivesse alunos resistentes às suas orientações, começava a debruçar-se sobre a temática da educação, escrevendo ensaios. Dispensado, após um ano, volta ao vale, mas decepciona-se e parte para Paris em 1742, com obras musicais, intentando fazer fortuna. Uma carta de apresentação, advinda da família Mably, deuIhe a chance de apresentar, sem sucesso, um de seus projetos musicais à Academia de Ciências.

Travando amizades entre a intelligentsia crescente da capital francesa, associa-se a Diderot. Na mesma época, aceita trabalhar como secretário do embaixador francês em Veneza, mas o ambiente é demarcado por desavenças entre empregado e contratante, fazendo com que o genebrino renunciasse um ano depois, retornando a Paris. Novamente instalado, entrega-se à música, conseguindo encarregar-se de uma adaptação de Les fêtes de Ramire, de Rameau e Voltaire. No mesmo ano, em 1745, conhece Thérèse, lavadeira e criada, sem estudos, que trabalhava em sua casa. Sem demora torna-se sua amante e companheira presente, concedendo-Ihe filhos dos quais Rousseau abriria mão posteriormente.

Em 1746, aceita novamente o posto de secretário, dessa vez, junto à família Dupin. Nesse período, consolida sua amizade com Diderot e cria um laço com outros partícipes do círculo dos enciclopedistas, sendo chamado a escrever verbetes musicais e outro sobre economia política: o reconhecido Discurso sobre economia política. Por conta de suas ideias progressistas, Diderot, presença constante do filósofo na época, foi detido em Vincennes. No caminho de uma das visitas ao camarada, Rousseau é profundamente marcado por um anúncio de concurso de ensaios proposto pela Academia de Dijon, levantando a questão "O progresso das ciências e das artes corrompeu ou purificou a moral?", que instigou no genebrino uma 
série de novas ideias e percepções que o fizeram desmaiar. Tal evento resultou no ensaio Discurso sobre as ciências e as artes e no prêmio do concurso. Com o raciocínio que o progresso das ciências e das artes havia degradado a moral, Rousseau ganhou notoriedade e muitos ensaios vieram em resposta (DENT, 1996). Ainda que esse novo leque de possibilidades se apresentasse, suas pretensões musicais ainda o perpassavam. Trabalha, então, na elaboração da ópera cômica $O$ adivinho da aldeia, alcançando, com ela, o reconhecimento do rei e de Madame Pompadour. Não fosse a força de seus sentimentos republicanos, teria possivelmente ficado sob a proteção e sustento de Luís XV.

Um novo concurso da Academia de Dijon trazendo indicativo de composição sobre a origem e legitimidade da desigualdade entre os homens, impulsionando seu Discurso sobre a origem e desigualdade. Com esse escrito, distancia-se do otimismo quanto ao progresso de seus convivas enciclopedistas, assim como da sociedade parisiense, acompanhado de uma considerável nostalgia de sua pátria:

[...] revela-se também na decisão de ir a Genebra em 1754, ser readmitido na Igreja Protestante e de reclamar seus direitos como cidadão. A caminho, escreveu para o Segundo discurso uma extensa e veemente dedicatória a Genebra, apresentando a cidade como modelo de perfeição para todas as comunidades humanas (DENT, 1996, p. 18).

Com base nesses novos sentimentos e reflexões, Rousseau passa a viver com Thérèse e sua sogra em uma casa de campo oferecida pela senhora d'Épinay, amiga conhecida em um salão frequentado pelo genebrino. Nesse lugar e em MontLouis, pertencente à região, constituíram os anos mais profícuos de sua vida. $O$ contrato social data dessa época, mesmo período em que se apaixona por Sophie d'Houdetot, cunhada da senhora d'Épinay, cujo sentimento ele expressa no romance A nova Heloísa. Em 1757, desentende-se com sua senhoria e se muda para MontLouis. Em seguida, seu caso com Sophie é encerrado. Paralelamente a esses acontecimentos, Rousseau cerca-se de novos amigos, membros da família Luxemburgo, os quais o acolhem em sua residência e o auxiliam a publicar Emílio. Em 1762, A profissão de fé do vigário saboiano, presente no Emílio foi considerada ofensiva à religião e, no mesmo ano, o genebrino foi condenado pela Faculdade de Teologia de Sorbonne, tendo seus exemplares queimados. Com indicativo de prisão, conseguiu refugiar-se em Môtiers, no principado de Neuchâtel. 
Completamente angustiado com a rejeição de seus escritos em praça pública, somada à humilhação e perseguição em Genebra, o filósofo renunciou à sua cidadania. Em Môtiers começou a interessar-se mais profundamente por botânica e dedicar-se à escrita. No entanto, já em 1764, Voltaire expõe, em panfleto, a vida pessoal de Rousseau, acusando-o de ter abandando os filhos.

O ano de 1767 marca o período em que foi permitido ao filósofo morar nos arredores de Paris, com o compromisso de não mais escrever. Três anos depois, no entanto, é calorosamente acolhido em sua última passagem por Paris, demonstrando uma forte retomada de sua reputação.

Além de escrever cartas pedagógicas sobre botânica, Rousseau dedica seus últimos anos a composições autobiográficas, muitas delas com claros indicativos de perturbação mental, como Rousseau juiz de Jean-Jacques. Entretanto, sua capacidade intelectual não estava, de forma alguma, comprometida: Considerações sobre o governo da Polônia, uma de suas mais importantes e simbólicas obras, foi concluída entre 1771 e 1772, a pedido do conde Wielhorski.

Nicholas Dent (1996) conclui suas considerações relativas à morte, reconhecimento e herança cultural do genebrino relatando:

Em maio de 1778, Rousseau mudou-se com Thérèse para Ermenonville, não muito longe de Paris central. Aí faleceu em 2 de julho, após breve enfermidade. Foi sepultado na Île des Peuliers em Ermenonville, e sua sepultura tornou-se lugar de peregrinação para os parisienses. Em outubro de 1794, seus restos mortais foram transferidos para o Panteão. [...]

Não há dúvida de que foi uma presença dominante durante a Revolução Francesa, e de que está hoje consagrado como uma das grandes figuras da civilização ocidental. (DENT, 1996, p. 22).

Não obstante, Albornoz (2006) atenta para a guinada que perpassou a filosofia política com as ideias rousseaunianas, da qual se abriram caminhos para estudos críticos da sociedade e das ciências sociais, movimentos emancipatórios, transformando e alargando a análise da vida social. Na filosofia da educação e, de modo mais abrangente e lúcido, na educação em geral, a partir do Emílio

[...] começam vida nova por uma nova forma de ligar formação e aprendizagem com a própria vida, implicando em uma nova atitude, ao mesmo tempo, ante a formação moral religiosa 
tradicional e a instrução moderna, vista como educação da e pela razão. (ALBORNOZ, 2006, p. 74).

Conhecer a vida de Rousseau, nos ajudará a compreender seu percurso e o que o motivou à reflexão e crítica a respeito da educação e política de seu tempo, incentivando-o no desenvolvimento de suas teorias político-educacionais e levandoo a deixar-nos como legado obras como Emílio, Considerações sobre o governo da Polônia, Contrato Social, entre outras que serão analisadas nessa pesquisa a partir da ótica de seus referenciais clássicos, que desde criança o inspiravam. 
O presente capítulo tem como objetivo resgatar, parcialmente, a história e a estrutura política de Esparta, que aqui consideramos político-educacional ou "político-formativa", como modelo apropriado por Rousseau para ilustrar ou reforçar aspectos fundamentais de seu pensamento voltado à formação do cidadão. Nosso intuito é apontar algumas características espartanas como fontes de inspiração para o genebrino em suas obras e arquétipo escolhidos para evidenciar as inúmeras lacunas e desvirtuamentos observados no cenário político e educacional do século XVIII. Nesse referencial clássico, podemos identificar uma comunidade política que enaltece seu legado cultural, cultuando a tradição oral deixada por Licurgo, estadista e pedagogo ${ }^{3}$, e reverenciando os mais velhos, gerontes; uma comunidade política que desde a mais tenra idade educa pela agoge as crianças para serem firmes defensores da pátria e do bem coletivo. Vislumbra-se um ambiente formativo, frugal, em que todas as inclinações dos membros buscam promover a vida comunitária.

Leduc-Fayette, em sua introdução de Jean-Jacques Rousseau et le mythe de l'antiquité (1974), explicita o lugar de Esparta como importante referencial político de Rousseau, notadamente presente em suas obras. A construção desse arquétipo é iniciada na Antiguidade, fortalece-se com a legislação de Licurgo e firma-se no século IV a. C., adquirindo visibilidade com os atenienses e Xénophon. Outra contribuição de destaque foi a dos filósofos pitagóricos, cujo mestre era reconhecido como herdeiro do legado espartano. Sócrates e seus mais famosos discípulos, com suas várias ressalvas contra a política espartana, contribuíram para a constituição do mito espartano.

A contribuição de maior importância, no entanto, foi a de Plutarco, ao nos apresentar Licurgo e seus personagens ilustres, promovendo a representação de Esparta em seu mais evidente patamar. Estendendo-se até a modernidade, tal imagem exerceu, como em vários autores, forte influência e fascinação em Rousseau.

Nas obras rousseaunianas, não é rara a possibilidade de encontrarmos referências acerca da Esparta clássica. Entre tantas, temos a presente no Tratado sobre Economia Política (2003d, p. 25):

\footnotetext{
${ }^{3}$ Conforme descrito por Jaeger (2001).
} 
Só tenho notícias de três povos que outrora praticaram a educação pública, a saber: os cretenses, os lacedemônios e os antigos persas; entre os três, ela foi muito bem-sucedida, tendo realizado prodígios entre os dois últimos.

O vínculo estabelecido entre os espartanos de caráter praticamente religioso - uma vez que a vida comunitária era assegurada pelos deuses - conferia à Lacedemônia uma unidade política que fascinava Rousseau. Essa unidade era ilustrada pelas celebrações e festas públicas. Para o autor, que acreditava que os cidadãos, juntos, constituem a cidade e promovem a república por meio da união e participação, não era difícil atribuir sentido a essa influência.

Apoiar-se em Esparta e Roma demonstra que, para Rousseau, havia regimes políticos melhores do que os que podia observar em seu próprio tempo. LeducFayette ratifica que o método rousseauniano não parte, necessariamente, de fatos e examinando um governo específico, mas faz uso de alguns aspectos desses referenciais clássicos para reforçar os elementos que considerava essenciais no seu pensamento político-pedagógico.

A autora ${ }^{4}$, enfatiza as críticas que Rousseau atribuía ao savant como o que carregava, de modo pejorativo, uma vã erudição, considerando-se filósofo. $O$ saber prático, no entanto, identificado pelo autor na Antiguidade, apresentava uma conotação completamente diferente, cujo termo sage diferenciava-se pelo fim a que sua postura virtuosa se fundava: o bem público.

O governo desta polis (capital da Lacedemônia, unidade regional grega), por suas marcantes e históricas características ${ }^{5}$, parece simbolizar muito do que o autor em destaque almejava em seu Estado pautado no Contrato Social e em Considerações. A Lacedemônia diferenciava-se das outras cidades-estados gregas, entre outros aspectos, por seu equilíbrio e constância política, ainda que batalhas e levantes a perpassassem. Esparta situava-se na região da Lacônia, ao sul da península do Peloponeso. Ligados à agricultura e à vida militar, os espartanos seriam descendentes dos dórios que, entre os séculos XII e X a. C., invadiram a Grécia.

Sobre a politeia da natureza lacedemônia, ensaio de Barros (1995), oferece

\footnotetext{
${ }^{4}$ LEDUC-FAYETTE, 1974, p. 76-78.

${ }^{5}$ As mais antigas tribos espartanas eram formadas, principalmente, por hileus, dimanes e panfílios, que embora figurassem no exército em seu período clássico, foram paulatinamente reconfiguradas em uma nova organização.
} 
subsídios que colaboram para a compreensão da política e educação espartanas, do qual se depreenderam elementos para o desenvolvimento que segue da temática em questão. O espírito espartano era, genuinamente, guerreiro. Na paz, os cidadãos aparelhavam-se e organizavam-se para a guerra, pois marcados pela exaltação da virtude aguerrida, a estreita ligação entre homem e cidade era latente: "No caso de perigo, todavia, a ideia da totalidade manifestava-se subitamente com a maior força" (JAEGER, 2001, p. 118). Para viver este espírito, o espartano tinha, a seu dispor, a mão de obra hilota e o serviço na indústria e no comércio (de estrutura muito simples, era executado pelos periecos- homens livres, mas não cidadãos), o que se configurava em condição essencial para o envolvimento político dos homoioi com o governo da polis. Esse envolvimento, para além de política pura, associava-se à ligação entre mito e religião, fortalecendo as bases de respeito à polis espartana e legitimando o vínculo afetivo por meio da crença compartilhada pelos cidadãos.

Como insiste Jaeger, desde o período primitivo da cultura grega, vislumbrase como todas as ramificações das atividades do espírito brotam "da raiz unitária da vida em comunidade" (JAEGER, 2001, p. 107). Descreve esse movimento como múltiplos rios que desembocam no mar da vida comunitária.

Rousseau valorizava essa personalidade patriótica, tantas vezes ilustrada por traços aguerridos, não deixando de fazer referências em suas clássicas obras, tal como as fez no Emílio, onde, no primeiro livro, apresenta exemplos que a ratificam, como ao contar o caso do lacedemônio Pedareta, recusado como membro do conselho dos trezentos, mas que sai exultante ao perceber que sua polis dispunha de trezentos homens mais valorosos que ele. Não distintamente, louva a postura de uma mulher espartana, que teria escutado a notícia de seus cinco filhos mortos em batalha e que, ainda nessa condição, encontrava-se ansiosa em saber se foram vitoriosos, agradecendo no templo, sem abatimento que fosse superior à vitória de sua pátria.

A estrutura política era constituída por realeza diárquica, Gerousía (Senado), Eforato $^{6}$ (colégio de magistrados) e Apela $^{7}$ (assembleia popular). Para ser cidadão e partícipe daquela estrutura, era necessário ser descendente de espartanos,

\footnotetext{
${ }^{6}$ Composto, por cinco dirigentes eleitos por um ano pela Apelá (assembleia), a eles cabia a maior responsabilidade na condução da polis. Fiscalizavam a cidade e os reis, podendo vigia-los na execução dos comandos em situação de guerra. Adicionalmente, podiam alterar leis antigas caso julgassem necessário.

${ }^{7}$ Composta por todos os cidadãos, os quais reuniam-se uma vez por mês, elegiam éforos e gerontes.
} 
colaborar para os syssitia (grupos de refeições comuns) e ter recebido a agogê, a educação da polis espartana (formação cívico-militar que engendrava o hoplitasoldado). O povo podia acessar os magistrados e elegia os gerontes ${ }^{8}$ (Senadores, homens com idade acima de sessenta anos, indicados por seus atributos morais). Os éforos, por sua vez, vigiavam os dois reis $^{9}$ (diarquia) que tinham como representantes (estes últimos prestavam juramento de fidelidade política).

Não é à toa que é empregado em Emílio o modelo do cidadão espartano, que tem como primeiro interesse, não a vida particular ou privada, mas sim, a vida pública. Sendo que a ausência deste tipo de cidadão nas sociedades modernas leva a falência da instituição pública. Como a noção perfeita de nação para Rousseau, é aquela em que todos os integrantes mais se aproximam do modelo ideal de cidadão, a hesitação de todos aqueles que entram em contradição, colaboram para incompatibilizar tal modelo de nação. (SILVA; ZANARDINI, 2002, p. 3).

Os próprios gerontes representavam uma percepção de vida espartana em torno da consideração pública atribuída à honra. O exemplo era encontrado na figura dos mais velhos, a qual era vista como aquela que nutria o ideal de doação à cidadeestado. A virtude, no entanto, não provém do indivíduo, mas da própria polis em seus ensinamentos e regras de conduta (ainda que avessa a leis escritas). Nesse contexto, a liberdade só pode ser cívica e vivida sob o prisma daquele que é cidadão. "A pátria não pode subsistir sem a liberdade, nem a liberdade sem a virtude, nem a virtude sem os cidadãos; isso é possível quando os cidadãos são educados para tal" (ROUSSEAU, 1996, p. 39).

Discorrendo sobre a realização da vontade geral, Rousseau define a virtude como a conformidade da vontade particular à geral e, para isso, o autor afirma que

Não é suficiente dizer aos cidadãos que sejam bons, é preciso ensiná-los a ser, e o próprio exemplo, que neste sentido é a primeira lição, não é o único meio que se deve empregar- o amor à pátria é o mais eficaz [...]" (Ibid., p. 34). Não obstante, "tinham consciência de não pertencerem a si próprios, mas à Pátria". (JAEGER, 2001, p.113).

\footnotetext{
${ }^{8}$ A Gerúsia era composta por vinte e oito anciãos com mais de sessenta anos de idade, nomeados pelos cidadãos em caráter vitalício. O conselho opinava sobre as questões importantes do Estado, propondo leis e julgando causas criminais (inclusive os reis, caso fossem acusados pelos Éforos.

${ }^{9}$ A realeza era hereditária. Os reis concentravam os poderes religioso, militar e judiciário. No entanto, a condução efetiva da polis se dava pelos éforos e pela gerúsia (conselho de anciãos), exceto em operações de guerra. Geralmente, suas funções resumiam-se às demandas religiosas de representação da cidade. Regularmente prestavam juramento de obediência às leis.
} 
Como se formava o cidadão espartano (homoioi), considerando a política e os valores pautados na cidade-estado? Os mesmos que acompanhavam os costumes da cidade eram aqueles que observavam e intervinham na educação com cuidado extremado: os éforos. A base de ensino do Eforato era genuinamente militar, formando o hoplita que, posteriormente, seria parte da constituição do corpo político da cidade.

A agogê, programa de educação e treinamento, formava as crianças desde os sete anos (inicialmente, em regime de tempo parcial) para o serviço da polis, da qual participavam até os trinta anos ${ }^{10}$. Inicialmente, as crianças eram reunidas em grupos (iles) que tinham um tutor (paidónomo) responsável, que também contava com a ajuda de um eiren (escolhido pelo paidónomo por destacar-se dos demais) para também comandá-los. Assumpção (2011), destaca que até os onze anos, era permitido que o jovem voltasse para a casa de sua família para passar a noite, mas a partir dos doze anos, era designado para dormir, em esteiras feitas de juncos, com seus companheiros de alojamento, até o final da formação. Aos dezoito anos, teria cumprido a primeira etapa da agoge, enfrentando missões ou desafios, nas quais deveria provar que colocava em prática seus ensinamentos. Aos vinte já se tornava membro efetivo do e exército. Ao longo de toda sua formação, praticavam ginástica, aprendiam a nadar, lutar, correr e praticar esportes que condicionassem seus físicos para a guerra. Adicionalmente, aprendiam a suportar o frio e a dor, não calçavam sapatos e usavam pouca roupa em ambas as estações. Sua alimentação era simples e era permitido roubar para comer: uma imitação muito próxima de uma real arena bélica: Na prática do ato de furtar para saciar a fome, o jovem desenvolveria a habilidade da astúcia, do silêncio e da perspicácia, ou seja, o agir sem ser notado" (ASSUMPÇÃO, 2011, p. 9), necessários para uma atuação engenhosa no campo de batalha. Fato interessante era que se fossem pegos roubando, eram punidos não devido a um apelo moral, mas por falharem em suas ações. Esse ritual iniciático estava muitas vezes associado a laços homossexuais envolvendo um jovem e seu tutor que também ensinava a arte da caça.

Havia, por exemplo, hábito de abandonar os jovens nas montanhas, sozinhos, munidos apenas de uma faca, para que aprendessem,

${ }^{10}$ Nessa faixa etária, conquistava o direito de se eleger às magistraturas mais significativas e residir com sua esposa e filhos. Mesmo cessando o amplo período de formação, suas obrigações militares só cessavam por completo aos sessenta anos. 
durante um ano, a sobreviver caçando e roubando durante a noite sem serem vistos (VEIGA, 1999, p. 28).

Com frequência, eram convocados a lutar entre si como preparo. Aprendiam a ler e escrever apenas o suficiente para o que a sociedade espartana traçava como objetivo. Eram instruídos, sobretudo, a dizer muito com poucas palavras. Por esse motivo, até hoje utilizamos o vocábulo "lacônico". Só após esse período o espartano passa a ser considerado cidadão completo, apto a deixar o regime de dedicação total da agogê para formar família e participar dos negócios públicos de Esparta.

Possivelmente, o ponto culminante deste processo educacional seria a aceitação do jovem adulto em um grupo de refeições comuns, o

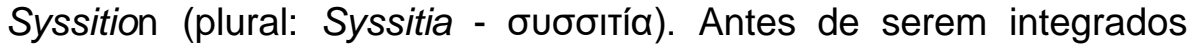
efetivamente em um destes grupos, era dado ao jovem o direito de observar, com o intuito de se beneficiarem com os feitos dos homens mais velhos. (ASSUMPÇÃO, 2011, p. 12).

Ao analisarmos o impacto formativo dessas refeições, entendemos como os feitos e a sabedoria dos mais velhos, quando os jovens se colocavam nesse processo de escuta e observação, exerciam conjuntamente uma função imprescindível na constituição dos hoplitas. Tornar-se um cidadão era honrar o legado dos anciãos e concidadãos.

Antes desde seu nascimento, o espartano ficava à disposição do Estado ${ }^{11}$. Os pais apresentavam a criança a um funcionário da polis (a decisão final cabia ao Senado), que avaliava suas condições físicas. Se julgassem que o Estado teria retorno ao investir em sua educação, ela participava do programa quando alcançasse a idade determinada. Se não, era abandonada à morte. Partícipes, todos os cidadãos que anteriormente desfrutaram dessa educação, partilhavam na assembleia pensamentos e julgamentos enraizados na mentalidade bélica: "Seja pela estrutura social, seja pela forma de educação, o cidadão é, aí, modelado no seio mesmo do Estado. Diríamos, antes, que o Estado é que põe o homem,

\footnotetext{
${ }^{11}$ A educação das meninas era relativamente similar a dos meninos: praticavam exercícios e tinham o corpo condicionado, uma vez que o Estado pretendia torná-las fortes para gerarem filhos robustos e saudáveis. Infelizmente, é pouco o que se sabe sobre esse quesito. No entanto, fica claro seu papel no seio da sociedade: renovar e perpetuar a tropa de guerreiros gerando filhos para a polis. Isso não significa que as mulheres estivessem à margem; é importante ressaltar que a maior parte dos templos de Esparta eram dedicados a divindades femininas. A deusa Atena era a mais adorada, mitologicamente reconhecida por representar sabedoria, estratégia e batalha.
} 
constituindo-o, ontologicamente, como cidadão". (BARROS, 1995, p. 47).

Ao vencer Atenas no início do século $\mathrm{V}$ a. C., por ocasião da guerra do Peloponeso, Esparta conquistou uma hegemonia inquestionável, a qual perdeu ao fim de três décadas, com a catástrofe de Leuctra ${ }^{12}$. Antes que se perdesse a mencionada hegemonia, ganhou ainda mais visibilidade dos teóricos da época e tornou-se o principal arquétipo.

Pode-se considerar esta polis um acampamento militar permanente, aspecto devido mais à sua formação histórica que de uma ânsia por conquista em si. Os dois reis heráclidas, que não dispunham de efetivo poder político (exceto durante as batalhas), procediam dos antigos reis dos exércitos do período das invasões dóricas. A assembleia espartana provém igualmente de um antigo agrupamento guerreiro. Em face de uma proposta desenvolvida pelo conselho dos anciãos, cabia a ela votar "sim" ou "não". O eforato seguia sendo a maior autoridade do Estado, reduzindo ao mínimo a influência dos reis. Nele residia o poder moderador no conflito entre senado e assembleia.

Dois elementos de grande importância para o sucesso militar foram o mito e a religião (BARROS, 1995, p. 47): a concessão da constituição de base apolínea (referência religiosa) e a herança mítica voltada à figura de Hércules (do qual descenderia Licurgo, principal organizador da polis). Seu politeísmo grego associado ao traço distintivo e marcante do culto aos heróis da guerra de Troia, adorados como deuses e dispondo de santuários, preservava o espírito agonístico da herança homerica. Veiga (1999) explicita como essas raízes ritualísticas eram elementos vivos nos jogos, festas e no espírito de guerra, na qual a sua agoge demarcava "[...] nítidas fases evolutivas" (p. 27) e representava um processo "[...] simultaneamente lúdico, bélico e religioso" (p. 28):

Numa ilha formada pelo rio Eurotas, perto do templo de Ártemis, uma divindade associada ao mundo da adolescência e à tensão entre selvagem e domesticado, ocorria um combate entre duas equipas de jovens, a cada uma das quais era entregue por sorteio um dos dois

\footnotetext{
${ }^{12}$ A admiração histórica por sua eunomia sofreu um considerável golpe quando a aversão dos gregos pelo opressor generalizou-se a partir do momento em que Esparta se viu dominada pela ânsia de poder (na época conduzida por uma política de expansão fria e calculista), perdendo o sentido de suas diferenciadas educação e disciplina. "O dinheiro, que antes Esparta mal conhecia, entrou na cidade em torrente, e 'foi descoberto' um velho oráculo, segundo o qual a ambição arruinaria Esparta" (JAEGER, 2001, p. 110).
} 
pontos de acesso à ilha. Na noite anterior, cada equipa sacrificava um cão em honra de Ares, o deus da Guerra; em seguida assistia-se a uma luta entre dois javalis, que servia para se fazer prognóstico acerca dos futuros vencedores. A competição começava de madrugada e consistia na ocupação da olha e na captura dos adversários, que eram atirados à agua, num misto de combate olímpico por equipes e de luta selvagem, já que todos os golpes eram admitidos. (CAMBIANO apud VEIGA, 1999, p. 27).

Por essa linhagem, a imagem de Licurgo reveste-se por uma aura divinizada, distanciando-se de ser visto como um simples homem. Sua legislação de caráter peculiar diferenciava-se da interpretação comumente aceita por constituição. Habituava os concidadãos a não desejarem a vida privada e isolada da comunidade, "Pelo contrário, levava-os a se consagrarem à comunidade e agruparem-se em torno do seu senhor, libertando-os do culto do eu pessoal, para pertencerem inteiramente à pátria" (JAEGER, 2001, p. 113). A vida espartana representava um sistema consistente e coeso pautado na crença que o mais alto fim do Estado era a paideia ${ }^{13}$, a estruturação da vida coletiva e sistematizada de acordo com normas concernentes à comunidade. Assim, a agoge espartana seria uma forma única e diferenciada de paideia, que visava a construção de um tipo ideal de cidadão, em prol do bem da comunidade política espartana.

Não sendo essa legislação uma compilação de leis civis e públicas, mas sim o nomos no sentido originário do termo, carregava uma tradição oral da qual apenas algumas leis primordiais foram transcritas.

Pelo contrário, em oposição à mania legisladora da democracia do séc. IV, têm-na como obra de sabedoria previdente de Licurgo, o qual, como Sócrates e Platão, dava maior importância à força da educação e à formação da consciência dos cidadãos do que às prescrições escritas. (JAEGER, 2001, p. 112).

Não por menos, Licurgo é descrito por Jaeger como grande estadista e pedagogo: o impacto da tradição oral na formação dos espartanos foi inigualável, tornando-se base dos ideais de educação da filosofia posterior.

\footnotetext{
${ }^{13}$ Ao traduzirmos o termo Paidéia como educação, a educação espartana seria diferente de qualquer outro tipo de Paidéia, tanto de sua época quanto posterior. No entanto, por almejar a formação de um modelo de indivíduos, mediante um propósito políade poderíamos identificar a Agôgé, assim como qualquer outra modelo de educação, enquanto uma forma de Paidéia. (ASSUMPÇẪ, 2011, p. 13).
} 
$\mathrm{Na}$ vida dos espartanos - nas suas refeições coletivas e na sua organização guerreira, instalada em tendas de campanha, no predomínio da vida pública sobre a privada e na estruturação estatal dos jovens de ambos os sexos e, finalmente, na rígida separação entre a população agrícola e industrial "plebeia" e os senhores livres, devotados só aos deveres citadinos, à prática guerreira e à caça - viu-se a realização consciente de um ideal de educação análogo ao que Platão propõe na República. Na verdade, Esparta foi, em muitos aspectos, modelo para Platão e outros teóricos da educação posteriores a ele, embora neles vivesse um espírito completamente novo. (JAEGER, 2001, p. 112).

Leduc-Fayette comenta a importância do legislador designando-o como arquiteto político do Contrato. Para a autora, o "milagre esparciata" decorria pela força de sua instituição na concessão de leis. Esparta seria "a obra de um homem providencial, entusiasta no sentido platônico do termo, um poeta das leis e que soube se esquecer de si em proveito da comunidade". A genialidade de Licurgo repousaria na sabedoria que teve no momento da imposição aos lacedemônios ao engendrar uma identificação férrea com a pátria e uma ocupação constante. "Tratase do amor da pátria, paixão violenta, exclusiva e que não admite nenhuma interrupção" (LEDUC-FAYETTE, 1974, p. 93).

As leis de Licurgo, que tendiam ao mesmo fim, seriam como rios a desembocar no mar representante da fusão do indivíduo na comunidade. É nesse sentido que, imbuído do processo de desnaturação, o qual transforma pessoas particulares que se associam em um corpo político em sua condição civil; o legislador por meio da instituição se torna como uma totalidade orgânica. O poder legislativo é o coração do Estado, envolvendo e possibilitando a integração efetiva dos indivíduos:

\begin{abstract}
A vontade geral, aliás, não é a soma das vontades particulares, mas a essência do eu comum, de tal sorte que ela é ao mesmo tempo subjetiva e objetiva, ela tem sua realidade em nós e fora de nós [...] de sorte que se houver voto, os minoritários devem tomar consciência que eles se enganaram por cegueira. (LEDUCFAYETTE, 1974, p. 94).
\end{abstract}

A máxima de Rousseau ao afirmar que o povo quer sempre o bem, embora 
nem sempre o veja, coloca o legislador em lugar daquele que exercerá o entendimento em relação à vontade geral. Assim, o genebrino recusa intermediários: o povo é ao mesmo tempo soberano e súdito. "A criação das leis, e a existência segundo a lei constituem, portanto, para o povo, uma relação imediata [e autêntica] de si a si" (LEDUC-FAYETTE,1974, p. 96).

De fato, podemos perceber claramente a influência espartana na formação do pensamento político-pedagógico de Rousseau. "Se quiserdes ter uma ideia de educação pública, lede a República de Platão", reforça o genebrino, "Não é uma obra política, como pensam os que só julgam os livros pelo título: é o mais belo tratado de educação jamais escrito" (ROUSSEAU, 2004, p. 13). Esse ideal de educação dirigido à polis foi extensamente analisado e utilizado como modelo digno de reconhecimento tanto por Platão quanto por Plutarco (profundamente influenciado por Platão), ambos imprescindíveis referenciais teóricos para o genebrino. A superação do individualismo e a formação de homens envolvidos com a pátria e com o bem comum era uma preocupação que não se restringia a Rousseau: o discípulo de Sócrates já carregava essa preocupação na obra enaltecida pelo genebrino.

Essa descrita educação, vinda e coordenada pela cidade-estado, marcava os espartanos e neles formava um espírito voltado a polis, por gosto e dever. De modo muito similar, em "Considerações Sobre o Governo da Polônia e sua Reforma Projetada" (2003a), Rousseau destaca, já no primeiro parágrafo do capítulo "A educação": "Cabe à educação dar aos espíritos uma formação nacional, orientando seus gostos e opiniões de modo que sejam patriotas por inclinação, por paixão e por necessidade" (ROUSSEAU, 2003a, p. 237). O vínculo estabelecido com sua pátria seria tamanho, que o indivíduo não conseguiria visualizar uma existência feliz isolado de sua nação e de seus concidadãos.

Jaeger (2001), ao escrever sobre Esparta, além de usar como fontes principais Xenofonte ${ }^{14}$, Plutarco (a biografia de Licurgo) e Platão, recorre e desenvolve suas análises tendo em vista as elegias de Tirteu ${ }^{15}$. O autor afirma que sua poesia modelou a vontade política espartana e sua fisionomia espiritual, constituindo a demonstração mais clara da força idealizadora desta polis, para além

\footnotetext{
14 Deixou-nos como legado para análise da temática, a obra a Constituição dos lacedemônios. O discípulo de Sócrates é descrito pelo autor como fruto do romantismo meio filosófico e meio político do século IV a. C., e escreve a respeito influenciado por sua experiência pessoal e conhecimento da polis. ${ }_{15}$ Poeta lírico grego do século VII a.C. Com seus encorajadores cânticos de guerra, é considerado alicerce fundamental na vitória dos espartanos na Segunda Guerra Messênia.
} 
de sua existência histórica. De fato, observamos como Rousseau detêm-se mais na força simbólica e ideal do legado espartano, e no potencial que tal herança tem de representar sua filosofia, a minúcias históricas. Platão, em seu sistema de formação, reservou a Tirteu e ao que representa tamanha importância ${ }^{16}$, que influenciou toda a cultura que se seguiu. Por isso este é o filósofo considerado o grande organizador do tesouro espiritual da nação (não por menos Rousseau se encarrega de conferir um estimado valor em $A$ República).

Em nenhum outro lugar a poesia grega revela tão claramente como a
criação poética brota da vida da comunidade humana. Tirteu não é
uma individualidade poética no sentido atual: é expressão do sentir
geral. Revela a convicção certa de todo o cidadão consciente. Por
isso se exprime com frequência na primeira pessoa do plural:
"Lutemos", "Morramos". E até quando diz "eu" não se trata do seu
eu subjetivo, pelo qual dá livre expressão à consciência do seu valor
artístico ou pessoal, nem do eu do chefe- já que Tirteu foi tido por
general-, mas sim do eu universal, da "voz pública da pátria", como
disse Demóstenes (JAEGER, 2001, p. 118).

Os poetas já eram, desde os tempos primitivos, mensageiros da arete. No entanto, com o mencionado poeta, essa função ressurgiu com uma nova áurea: a lenda fez dele um enviado de Apolo, encontrando significação simbólica no fato de surgir em caso de necessidade, o mentor espiritual apropriado, a própria face do que seria a nova arete, a "exigida pelas circunstâncias". (JAEGER, 2001, p. 119).

A elegia de Tirteu, diferentemente da epopeia, expressa uma íntima vinculação entre o que fala e aqueles a quem se dirige. Nesse caso, trata-se dos cidadãos, da juventude espartana. Esse formato exortivo destrincha com clareza a base educativa da elegia. O conteúdo mítico da epopeia age em um mundo ideal, no ideal homérico, já os discursos da elegia situa-se na realidade do poeta e aos que ele comunica. É desse modo, que por delinear uma autoridade moral e política inédita, Tirteu empreende uma nova ação formativa:

A ideia de uma comunidade citadina que transcende qualquer individualidade e para a qual todos vivem e morrem. O ideal homérico da arete heroica transforma-se no heroísmo do amor à

16 "Diz-nos nas Leis que a Esparta do séc. IV tem em Tirteu a mais alta manifestação do espírito do Estado dórico, cuja finalidade é a educação pública dos cidadãos, quer dizer, a formação na destreza guerreira" (JAEGER, 2001, p. 127). 
pátria. O poeta aspira a impregnar deste espírito a vida de todos os concidadãos. Quer criar um povo, um Estado de heróis. A morte é bela quando é a de um herói. (JAEGER, 2001, p. 120).

A terceira elegia de Tirteu é descrita por Platão como a que mais caracterizaria o espírito aguerrido de Esparta: '[...] se tivesse todas as glórias do mundo, mas não possuísse o valor guerreiro, não quereria honrá-lo. Não dará boas provas de si na luta se não for capaz de encarar a morte [...] - isto é arete" (TIRTEU apud JAEGER, 2001, p. 121). A maior virtude seria a conquistada pela glória da polis, quando a preservação da comunidade é colocada à frente do bem individual, mesmo que essa escolha custasse a vida do guerreiro. Com essa nova configuração de arete, existira apenas uma medida para aferi-la: a cidade e o que a beneficia ou a prejudica. Esta eleva virtude aguerrida garantiria, adicionalmente, a imortalidade do hoplita por sua honra e pela glória alcançada à sua cidade:

Mas aquele que cai entre os combatentes e perde a vida bem-amada cobre de glória a sua cidade, os seus concidadãos e o seu pai, ao ser chorado por todos, novos e velhos (...) a sua dolorosa memória enche a cidade inteira e são honrados entre os homens o seu sepulcro (...) e toda sua linhagem; a honra do seu nome não se extingue jamais e, mesmo que jaza no seio da terra, torna-se imortal ${ }^{17}$. (TIRTEU apud JAEGER, 2001, p. 122).

Desse modo, o hoplita alcançaria a perfeição por meio da imortalidade da sua memória no seio da comunidade pela qual viveu ou morreu. A polis é, nessa nova concepção de arete política, o terreno onde se condensa toda a humanidade e divindade, transformando da concepção religiosa anterior advinda da arete da epopeia. Em outra elegia comentada, a Eunomia, o poeta revela-se como mentor e representante da ordem política do Estado. Seu objetivo é educar o povo no princípio fundamental da "legislação" espartana, comparável à prosa dórica recolhida por Plutarco ${ }^{18}$ na sua Vida de Licurgo.

\footnotetext{
17 TIRTEU. Citado um fragmento dos líricos gregos pela Anthologia Lyrica Graeca, ed. E. Diehl (Leipzig, 1925).

${ }_{18}$ Nascido no ano 46, em Atenas, Plutarco estudou em sua cidade de origem e pelo menos duas vezes esteve em Roma, sede do Império que dominava os gregos na época. Exerceu função de sacerdote e manteve uma vida social ativa, desenvolvendo relações com diferentes autoridades do período. Tal proximidade o permitiu adentrar nas culturas helênica e romana. No Emílio verifica-se como Rousseau o reverencia como historiador ao pensar o ensino de História, ao apresentá-lo Vidas Paralelas, obra que contém biografias de personalidades romanas e gregas, como a dos Imperadores Alexandre e Júlio César, organizadas aos pares com o intuito de comparar feitos e caráter,
} 
demarcando as influências desses homens que apresentavam valores muito próximos (constituintes da civilização latina). A exposição das ações públicas e da vida particular exerceria efeito exemplar e sensibilizaria Emílio ao jogo das paixões humanas, instruindo-o no conhecimento da alma humana. Aqui, a educação moral é exaltada para a futura prática do bem e da justiça. Quando reguladas na ordem civil, as paixões teriam sua força canalizada na manutenção do corpo político, ressignificando o sentido da vida pública. SOUZA (2001), obra de referência para as menções a Emílio desta presente nota, disserta sobre uma história exemplar, que seria a história preconizada por Rousseau, da qual se poderia extrair lições morais e forneceria a Emílio recursos para seu autoconhecimento. 


\section{A REPÚBLICA ROMANA E A FORMAÇÃO PARA A LIBERDADE}

Tal como Esparta clássica, a Roma republicana representa, para Rousseau, outro fundamental referencial teórico e um dos pilares de sua Filosofia, inspirando-o no desenvolvimento de sua teoria política. Diferentemente de Esparta, no entanto, aqui não vemos uma proposta de Educação pública, uma vez que a educação era confiada às famílias: o lar era, para a república, a escola da cidadania, onde os primeiros ensinamentos eram promovidos. Apesar de, nesse recorte histórico, não haver uma proposta estatal no que diz respeito à Educação, encontramos, na Roma republicana, outro propício ambiente formativo que fomentava, nas crianças e jovens, o amor à pátria, respeito ao legado cultural existente e postura cidadã ativa na manutenção dos direitos conquistados e da liberdade. A vida comunitária é, também aqui, aspecto central entre os romanos.

As famílias romanas tinham clareza do seu papel junto à preservação da história, identidade e cultura romanas. Estas, por sua vez, eram ratificadas na vida cívica, por exemplo, em eventos públicos que apresentavam um alto teor simbólico, de formação e constituição do cidadão romano, como é o caso do ritual de passagem da toga pretexta para a toga civilis. Sobriedade dos costumes e virtude política eram atributos de honra entre os mais velhos, admirados pelos jovens. Nesse capítulo, procuraremos explorar um pouco da história e desses pontos comentados, tão caros a Rousseau, uma vez que representam, em muitos aspectos, o que o genebrino enaltece no processo de formação do cidadão.

O período monárquico romano (sendo este regime político demarcado, em sua definição, por um único representante que detém a autoridade) remonta, aproximadamente, à metade do século VIII a. C., estendendo-se até 509 a. C., que antecede a transição à República, quando Tarquínio, o Soberbo, foi deposto por uma revolução que expulsou os etruscos e impôs a República em Roma, regime que estendeu-se até 27 a.C.. Mais que o poder de um só,

[...] a relação entre o rei de Roma e o povo era considerada análoga à relação entre senhor e escravo. O estado de opressão e arbitrariedade gerava nos diversos estamentos um sentimento de inconformidade e revolta". (CEREZUELA, 2006, p. 15). 
Por meio das revoltas, os plebeus conquistaram vários direitos sociais e políticos ao longo dos anos: fim da escravidão por dívidas, criação dos tribunos da plebe (direito a vetar decisões do Senado que fossem prejudiciais aos plebeus), igualdade civil (permissão de casamento entre plebeus e patrícios), igualdade religiosa e ampliação de direitos políticos (eleger representantes para diversos cargos políticos). Desse modo, o enfraquecimento da monarquia pela mencionada relação análoga, que se intensifica no final do século $\mathrm{VI}$ a. C., conduziu a uma substituição progressiva da realeza por uma organização política fundamentada em magistrados, os quais eram funcionários do Estado dotados de poder judicial ou administrativo. As magistraturas correspondiam a cargos anuais com mais de um ocupante para evitar a concentração de poder em um único responsável. (CEREZUELA, 2006).

No capítulo IV do Contrato, Rousseau (1978, p. 124-131) dedica-se a e escrever e comentar suas impressões a respeito dos comícios romanos, ou como "o mais livre e poderoso dos povos da Terra exercia seu poder supremo" debruçandose sobre a história romana. Reforça que muito do que se chegou de informação sobre os primórdios de Roma, não passou de fábulas. $\mathrm{O}$ autor explica que, após a fundação de Roma, o exército do fundador, composto de albaneses, sabinos e estrangeiros, foi organizado em três classes. Cada tribo foi subdividida em dez cúrias, e cada cúria em decúrias, comandadas por curiões e decuriões. Para essas divisões militares, foram designados de cada tribo dez cavaleiros ou cavalheiros. Devido ao aumento crescente da tribo dos estrangeiros, Servius alterou a divisão para quatro tribos. A essas, outras quinze foram criadas, e posteriormente outras, até encontrarse em trinta e cinco delas, cada qual com seus deuses, oficiais e festas, total conservado até o final da República.

Assim, tudo o que Roma tinha de ilustre vivia nos campos e cultivava as terras, tornando-se costume só aí procurar os esteios da república. Sendo esse o estado dos mais dignos patrícios, acabou respeitado por todos; a vida simples e trabalhosa dos camponeses foi preferida à vida ociosa e corrupta dos burgueses de Roma, e não houve quem, infeliz proletário na cidade, não se tornasse, como trabalhador dos campos, cidadão respeitável. Não foi sem motivo, dizia Varrão, que nossos magnânimos ancestrais estabeleceram na aldeia o viveiro desses homens fortes e bravos que os defendiam em tempo de guerra e os nutriam em tempo de paz. Plínio diz positivamente que as tribos dos campos eram dignificadas por causa dos homens que as compunham. [...] (ROUSSEAU, 1978, p. 126). 
De fato, como corrobora Leduc-Fayette (1974), a frugalidade, a sobriedade de costumes, conferiam à Roma um segundo traço característico após a virtude política. Adicionalmente, a autora enfatiza o valor que Rousseau atribuía à austeridade e rusticidade dos tempos áureos republicanos, no qual os habitantes se consagravam aos trabalhos da terra, "em uma existência bem distanciada de toda preocupação especulativa ou $\operatorname{artística~}^{19}(. .$.$) e sorte de imanência próxima do estado de natureza"$ (p. 113). Igualmente, Marrou atenta para a preocupação dos romanos do desenvolvimento das virtudes campesinas:

[...] amor ao trabalho árduo, frugalidade, austeridade. A criança romana ouvia exprobra-se o luxo corruptor e celebrar-se 0 desprendimento dos velhos cônsules ou ditadores como Cincinato, que cultivavam a terra com os próprios braços e que o voto do senado arrancava à charrua para leva-los à suprema magistratura. (MARROU, 1990, p. 369).

Com o passar do tempo, os censores do governo que organizavam as inscrições e migrações entre as tribos, foram permitindo que os cidadãos se realocassem onde desejavam. Assim, paulatinamente, as tribos se mesclaram. Ainda sob o comando de Servius, foi elaborada outra divisão embasada nas posses $^{20}$ de cada um, em um total de seis classes.

Nenhuma lei recebia a sanção, nenhum magistrado era eleito, senão nos comícios; e como não havia cidadão que não estivesse inscrito numa cúria, numa centúria ou numa tribo, conclui-se que nenhum cidadão era excluído do direito do sufrágio e que o povo romano era verdadeiramente soberano de direito e de fato. (ROUSSEAU, 1978, p. 128).

Inicialmente, sendo grande número de plebeus das classes dos mais abastados, os tribunos equilibravam o crédito dos patrícios. Os comícios por tribos, por sua vez, constituíam o conselho do povo romano. Os tribunos convocavam os comícios, que eram eleitos e encaminhavam deliberações: "Não somente o senado aí não fruía de nenhuma posição especial como também não possuía sequer o

\footnotetext{
${ }^{19}$ Aqui a autora faz referência à influência dos parâmetros gregos de educação, que começam a penetrar a cultura romana no período de transição entre República e Império.

${ }^{20}$ Para se ter o direito de empunhar armas em defesa da pátria, era preciso ter um lar. Desse modo, a sexta classe não fornecia soldados ao exército, tampouco e eleitores no Campo de Marte.
} 
direito de a eles assistir" (ROUSSEAU, 1978, p. 130). Os comícios por centúrias, ao contrário, eram mais favoráveis aos interesses da aristocracia. Sobre 0 recolhimento dos sufrágios, Rousseau enaltece o procedimento inicial, no qual se votava em voz alta, por ser considerado um bom hábito ao preservar a honestidade entre os cidadãos, que se sentiriam envergonhados ao decidir de forma injusta diante da comunidade. Quando deixou de ser desse modo, passando a ser secreto, o genebrino defende que começaram a corromper-se e ser negociados.

No período republicano, o governo de Roma constituía-se por dois Cônsules, pelos Senadores e Tribunos da Plebe. Uma parcela do poder era destinada a cada uma das instituições. Essa formação mista possibilitava uma sintonia entre diferentes formas de governo, a saber: monárquica (representada pelo Consulado), aristocrática (Senado) e democrática (povo). Os Cônsules dispunham do poder administrativo e militar; o Senado elegia os primeiros; enquanto os cidadãos, que defendiam os interesses do povo, elegiam os Tribunos da Plebe (resultado de conflitos ente plebe e Senado):

\begin{abstract}
Assim, quando os Tarquínios (os quais refreavam os aristocratas pelo terror que lhes inspiravam) deixaram de existir, foi preciso buscar novas instituições que os substiuíssem, com o mesmo efeito. Em consequência, só depois dos distúrbios, das contínuas reclamações e dos perigos provocados pelos longos debates entre nobres e plebeus é que se instituíram os tribunos, para a segurança do povo. A autoridade desses novos magistrados foi cercada de tantas prerrogativas e prestígio que puderam manter o equilíbrio entre povo e Senado, oferecendo um obstáculo às pretensões insolentes da nobreza. (MAQUIAVEL, 1994, p. 29-30).
\end{abstract}

Essa conexão e distribuição das atribuições eram fundamentais para o equilíbrio político-administrativo. Cerezuela (2006) adverte que há diferentes concepções políticas que caracterizam autores republicanos, considerando que pode desde aproximar-se do Absolutismo até um apoio extremado da voz da maioria. No entanto, reforça a ideia de que governos republicanos pressupõem algum nível de compartilhamento de poderes, ainda que não desconsiderem conflitos de interesses. O desafio é a capacidade de acomodar as divergências no âmbito político, objetivando o bem comum: 
aos interesses dos diferentes partidos é o maior problema dos republicanos. Uma ou outra facção até pode vir a controlar o governo e usá-lo para perseguir seus próprios interesses, ao invés de usá-lo para o bem comum. Para prevenir os inconvenientes causados pelo facciosismo, os teóricos republicanos desenvolveram uma variedade de estratégias: um sistema constitucional baseado no sistema de freios e contra-pesos ou ainda a distribuição de terra e de outras formas de propriedade. (CEREZUELA, 2006, p. 17).

Escrita no ano 51 a.C., Da República está sistematizada na forma exemplar dos diálogos platônicos. O autor procura, em seus diálogos, aflorar naturalmente os assuntos em pauta, articulando suas discussões com a invocação de eventos históricos. No relato de Cícero, Cipião Emiliano, o qual representa o pensamento do orador, é visitado por amigos e parentes. Com o desenrolar do texto, Cipião é chamado a dar sua opinião quanto à melhor organização política. Define a República como sendo uma organização social com fundamento jurídico, voltada para o bem de todos.

Cícero, intentando analisar a grandiosidade do legado da República romana, contribui com sua percepção de como seria uma organização política justa (justiça entendida como razão marcada pela natureza, a qual preceituaria o bem), a partir da ideia de que uma ordem jurídica comum a todos colaboraria para a união de pessoas marcadas por status diversos por meio de uma lealdade patriótica e legal. Para o filósofo, se cada um se mantiver comprometido com sua função e seu lugar na vida civil, o bem público é, consequentemente, assegurado. Para a preservação deste bem, no entanto, é preciso que os cidadãos sejam ativos na esfera pública. Os homens, nesse sentido, possuiriam um sentimento natural e genuíno que os impulsionaria a se associarem.

\footnotetext{
É pois, - começou o Africano, - a República coisa do povo, considerando tal, não todos os homens de qualquer modo congregados, mas a reunião que tem seu fundamento no consentimento jurídico e na utilidade comum. Pois bem: a primeira causa dessa agregação de uns homens a outros é menos a sua debilidade do que um certo instinto de sociabilidade em todos inato; a espécie humana não nasceu para o isolamento e para a vida errante, mas com uma disposição que, mesmo na abundância de todos os bens, a leva a procurar o apoio comum. (CÍCERO, 2001, p. 30).
}

Ao explicitar as formas de governo, Cícero clarifica seu pensamento 
pontuando que, cada uma delas, tem seu caráter e natureza condicionados pelo poder que a gerencia. O regime político escolhido deveria, então, estar em sinergia com as pretensões e necessidades do povo. O mencionado processo sinérgico não admitiria um governo puramente aristocrático ou monárquico, já que conflito de interesses deles advindos inviabilizariam a concórdia entre cidadãos. O plano do filósofo é um regime que permita a participação de todas as formas de governo (monarquia colaborando com a afeição a uma figura referencial; a aristocracia com a erudição, e o popular com a liberdade advinda da força da comunidade).

Quase sempre o pior governo resulta de uma confusão da aristocracia, da tirania facciosa do poder real e do popular, que às vezes faz sair desses elementos um estado de espécie nova; é assim que os Estados realizam, no meio de reiteradas vicissitudes, suas maravilhosas transformações. O sábio tem a obrigação de estudar essas revoluções periódicas e do moderar com previsão e destreza o curso dos acontecimentos; é essa a missão de um grande cidadão inspirado pelos deuses. Por minha parte, creio que a melhor forma política é uma quarta constituição formada da mescla, e reunião das três primeiras. (CÍCERO, 2001, p. 31-32).

Por meio dos bons hábitos e costumes, ensinados pela tradição e pelas instituições, o regime republicano poderia possibilitar a sua harmonia e manutenção, cultivando a virtude pública. Não obstante, Rousseau (2003a, p. 230) afirma que Roma sustentou a virtude como seu principal objetivo de Estado, imbuída em suas leis. "O que se chama tão naturalmente a virtude "romana" não é senão a moral da cidade antiga, à qual permaneciam fiéis os romanos da República", representando o ideal coletivo de consagração do indivíduo ao Estado (MARROU, 1990, p. 357). Cícero defende que a República romana como exemplo edificante configurou-se pela prioridade concedida aos princípios do bem coletivo, abraçando a participação dos cidadãos nos assuntos do Estado, como podemos observar ao se referir à atuação do tribunato 21 :

É mais sagrado e mais reverenciado como defensor das leis que o
príncipe que as executa e o soberano que as dá. Foi o que se viu
com bastante clareza em Roma, quando seus altivos patrícios; que
sempre menosprezaram todo o povo, foram forçados a dobrar-se
perante um simples oficial do povo que não tinha auspícios nem
jurisdição. O tribunato, sabiamente temperado, representa o mais
firme apoio de uma boa constituição; mas, por pouca força que tenha

${ }^{21}$ Rousseau considera o tribunato o mais insigne conservador das leis, servindo para proteger 0 soberano (o próprio povo) contra um governo despótico. (ROUSSEAU, 1978, p. 131-132). 
de mais, tudo subverte; no que concerne à fraqueza, ele naturalmente a não possui [...]. (CíCERO, 2001, p. 58-59)

Esses mencionados bons hábitos e costumes, a virtude cívica, foram sustentados e embasados na educação em vigência na República romana. Roma, nesse período, não aderiu a uma política educacional propriamente dita. Apesar de ter adotado muitas características do helenismo, não concedeu o mesmo trato à educação. Isso porque era prática do Estado romano dirigir essa responsabilidade à família ou à iniciativa privada (praticamente inexistente, sua proporção não exercia impacto significativo). Esse cenário foi sendo paulatinamente alterado com o advento do Império, assunto sobre o qual não iremos nos deter. No entanto, cabe adiantar que a constatação de tal mudança não agradava ao genebrino, para o qual "a natureza não nos destinou de forma alguma a pesquisas vãs", acrescentando "Até então, os romanos haviam se contentado em praticar a virtude, e tudo foi perdido quando começaram a estudá-la". (ROUSSEAU apud LEDUC-FAYETTE, 1974, p. 113).

Roma privilegiava o conhecimento prático em detrimento de um conhecimento teórico. Movido pelas necessidades práticas, o cidadão romano valorizava ao máximo o poder de agir. Em comparação com o povo intelectual e de graças artísticas, como o ateniense, o romano era formado por camponeses que valorizavam as esferas profissional, militar, política e agrícola (MELO, 2007). No momento que precisaram conferir à formação intelectual um novo perfil, o fizeram tendo em vista sua utilidade prática, o que caracterizava sua mentalidade pragmática: a educação deveria preparar para a vida.

Não havia, na antiga educação latina, característica propriamente intelectual (desenvolvida sob a influência grega): "O jovem romano aprende unicamente o que deve saber um bom proprietário campesino e antes de tudo a agronomia". (MARROU, 1990, p. 372). Faz-se necessário o aprendizado da valorização do patrimônio, sabendo dirigir a exploração, supervisionar o trabalho do campo, aconselhar subintendentes. Segundo Marrou, a tradição enciclopédica romana existente tratava-se de aplicações práticas, concretizando-se em coleções de manuais e legados de eruditos polígrafos, como a obra de A. Cornélio Celso que publicada no reinado de Tibério, exemplificada por Marrou, era composta por vinte livros, "onde tratava sucessivamente de agronomia, de arte militar, de retórica, de 
filosofia, de medicina e de direito" (1990, p. 373). A retórica e a filosofia representavam a vertente grega de contribuição, mas todo o restante era marcado pela verdadeira cultura latina, de "espírito realista do romano".

Desse modo, constituiu-se, nos romanos, um espírito de notável preservação da tradição, cristalizando-se em um comportamento que reverenciava os costumese a sabedoria dos mais velhos: na manutenção dos costumes antigos estaria a chave do poder e da força de Roma. O interesse coletivo, da comunidade, seria sempre soberano. O bem público deveria ser para a pátria a lei suprema, destaca Melo ao relembrar a máxima de Cícero.

No perfil ético do homem ideal romano destacam-se, dentre outras, três virtudes cardeais: a pietas (piedade), referente aos deuses, à família e à compaixão para com os vencidos - humanitas, magnanimitas; a fides (lealdade), relativa aos pactos políticos, militares, individuais (no sentido da amizade), da palavra dada, etc.; e a gravitas (dignidade), que expressava o domínio de si mesmo, a capacidade para se enfrentar situações imprevistas, a serenidade na solução de problemas e na emissão de juízos. Estas eram virtudes específicas daqueles que deveriam exercer o iustum imperium (autoridade legítima) no exército e na República. (MELO, 2007, p. 3).

A Educação Física, como ratifica Marrou, atrelada à formação de soldadoslavradores, era extremamente utilitária: “[...] vêde, em Plutarco, o que o velho Catão faz seu filho aprender: a esgrima, lançamento de dardo, manejo da espada, volteio, esporear cavalos e manejar qualquer arma; combater a murros, suportar o frio [...]." (1990, p. 370). No circo, parte da juventude aristocrática romana, apresentava a equitação que, diferentemente da Grécia com ênfase nas corridas, dispunha de um caráter militar acompanhado pelos desfiles com armas. Adicionalmente ao circo, os combates do anfiteatro não eram reservados a profissionais e escravos, apenas, pois a esgrima, aprendida sob a instrução de um gladiador, fazia parte da formação. "o anfiteatro, os jovens das melhores famílias participavam das "caças", venationes, de combates contra fera, ursos e leões". (MARROU, 1990, p. 372).

O autor acentua outra característica distintiva do cidadão romano do período em questão, integrada à virtus - como excelência global e força de caráter do vir bônus - conceito que para Melo contém respaldadas analogias com a arete grega. No Contrato, ao caracterizar, sinteticamente, alguns povos, Rousseau completa seu 
raciocínio: "Em uma palavra, além das máximas comuns a todos, cada povo reúne em si alguma coisa que o dirige de modo todo especial e torna sua legislação adequada somente a si mesmo" (ROUSSEAU, 1978, p. 68) - segue mencionando alguns povos e finaliza afirmando que o objetivo mais importante de Roma era a virtude.

Assim sendo, o pressuposto fundamental do direito e da sociedade residia no cidadão justo, o qual só teria sua existência reconhecida se permanecessem vigentes a legislação e os costumes tradicionais (leges et instituta maiorum), cuja representação mais significativa está no exemplo maiorum: o modelo dos mais velhos, dos que haviam se destacado pela postura virtuosa tanto na esfera familiar, quanto na política. Como destaca Silva (2003, p. 155), "[...] os jovens tomavam contato com os mais velhos desde a mais tenra idade e, com isso, sua educação repousava no respeito ao 'costume ancestral', na tradição nacional e familiar".

A educação romana realizava-se na esfera do lar e consistia, em um primeiro plano, nos cuidados físicos e na aquisição de hábitos morais. A família era, então, elemento-chave da sociedade, assumindo papel indispensável no processo educativo informal: "es el núcleo de la ciudad y como el semillero de la República". (BONNER 22 apud MELO, 2007, p. 6).

Ao dissertar sobre os povos que obtiveram êxito na educação pública, no Economia Política, Rousseau (2003d) menciona três (cretenses, lacedemônios e antigos persas), e destaca o caso de Roma como uma exceção:

\footnotetext{
É notável que os romanos a tenham dispensado, mas a verdade é que durante quinhentos anos Roma foi um milagre contínuo, que o mundo não pode esperar que aconteça outra vez. Engendrada pelo horror que tinham à tirania e aos crimes cometidos pelos tiranos, assim como pelo seu patriotismo inato, a virtude dos romanos fez de cada casa uma escola de cidadania ${ }^{23}$.
}

Continua com uma ressalva, demonstrando certa reserva sobre o poder sem precedentes dos pais sobre os filhos, sendo por vezes mais temidos que os próprios governantes. No entanto, prevalece a mensagem de reconhecimento do genebrino à essa formação cidadã no seio familiar, da qual o futuro cidadão poderia extrair mecanismos internos de comportamento patriótico.

22 BONNER, Stanley. La educación en la antigua Roma. Barcelona: Herder, 1984.

${ }^{23}$ ROUSSEAU, 2003d, p. 25). 
No livro I do Emílio, Rousseau (2004) retira de Vidas Paralelas, de Plutarco, o grande exemplo de Catão, o qual ressalta ter governado Roma com glória. "educou ele próprio o filho desde o berço e com tal cuidado que tudo abandonava para estar presente quando a ama, isto é, a mãe, o virava e lavava".

Silva (2003, p. 154), comentando a obra nomeada "Marco Catão", de Plutarco, traz referências sobre Catão, um dos mais renomados políticos e cidadãos romanos, conhecido por levar uma vida temperante e disciplinada. Decide educar o próprio filho, a fim de cumprir o papel que acreditava exercer na preservação da história, identidade e cultura romanas, assumindo o ensino das letras, do direito e da ginástica: "Afirma que redigiu um livro de história do próprio punho, em letras gordas, para que o filho tivesse em casa meios de conhecer as antigas tradições da pátria". (PLUTARCO ${ }^{24}$ apud SILVA, 2003, p. 155).

Essa educação, embasada na iniciação no modelo de vida tradicional, tinha como alicerces o respeito e a assimilação dos costumes ancestrais (os mores maiorum). No seio da família, a figura de maior destaque estava reservada ao pater familias, o qual dispunha da patria potestas:

A terminologia pater, além de designar "geração", expressava com particular ênfase as idéias de "proteção e poder". O pater familias era uma pessoa sui iuris, cujo status não estava vinculado à sua idade ou ao seu estado civil. Além do vínculo natural, a família romana também tinha um vínculo jurídico, que determinava a submissão dos seus componentes à patria potestas. (MELO, 2007, p. 6).

Por esse poder conferido, o Estado não interferia na vida familiar. Ainda na República, o caráter rígido e absoluto do pater familias foi amenizando em alguns aspectos, por exemplo, na prática de abandonar filhos indesejados, como exemplifica Melo. Mesmo não dispondo da patria potestas, a matrona romana exercia papel imprescindível na educação dos filhos, muito superior a do mundo grego.

A influência da mãe marcava toda a vida do homem: donde o valor simbólico que a tradição ligava ao famoso episódio de Coriolano, revoltado contra Roma marchando sobre a cidade, à frente dos volscos: nem os rogos dos embaixadores do povo romano, nem os dos sacerdotes puderam detê-lo, mas ele cedeu às censuras de sua mãe. Anedota talvez lendária, mas que traduzia um sentimento real: em plena época histórica, no século II, no I antes de nossa era,

24 PLUTARCO. Marco Catão. In: Paulo: Paumape, 1991. v. 2. p. 288. . Vidas Paralelas. Tradução de Wilson César Cardoso. São 
conhecemos o papel desempenhado por Cornélia, mãe dos Gracos, por Aurélia, mãe de César, por Átia, mãe de Augusto, na vida de seus filhos, aos quais haviam sabido educar para fazê-los chefes. (MARROU, 1990. p. 362).

No decorrer dos sete primeiros anos da vida da criança, a mãe responsabilizava-se pela ação educativa, ocupando-se das suas necessidades biológicas, intelectuais e morais. Quando por algum motivo não podia exercer essa função, procurava entre os parentes respeitados outra pessoa qualificada para ser a primeira mestra.

Após os sete anos, o pai iniciava sua intervenção na educação do filho, enquanto a filha mantinha-se na companhia da mãe, aprendendo as tarefas domésticas. Enquanto os pobres preparavam os filhos para o aprendizado de um ofício, os ricos ensinavam leitura e escrita (caso não tenham sido ensinadas pela mãe), cálculo, as leis das Doze tábuas, exercícios físicos e o manejo de armas, além da veneração às virtudes morais e cívicas: "Como Roma nunca abandonou o ideal que consagrava o indivíduo ao Estado, em todas as suas atividades e funções, nos seus passeios e visitas, o pai fazia-se acompanhar dos filhos, a fim de, por meio da própria vida, prepará-los para a vida". (MELO, 2007, p. 7).

Desse modo, era destinada ao pai a introdução gradual do filho na vida pública, mesmo que outros mestres perpassassem sua trajetória:

[...] os filhos acompanham o pai, seguindo-o até o interior da cúria, onde com ele assistem até mesmo às sessões secretas do senado; iniciam-se ao seu lado em todos os aspectos da vida que o espera, instruindo-se pelos seus preceitos e mais ainda pelo seu exemplo. (MARROU, 1990, p. 362).

A conclusão dessa fase cessava entre os dezesseis e dezessete anos, marcada por um ritual no qual o adolescente despojava-se de uma túnica com uma franja colorida, toga pretexta, e dos símbolos que representavam a infância, envolvendo-se com outra totalmente branca, a toga civilis, com a qual apresentavase no foro. Este era um sinal de seu reconhecimento como cidadão, integrado na vida pública:

Neste estágio da formação, antes de dar início ao serviço militar, o jovem deveria dedicar-se por um ano ao tirocinium fori, a 
"aprendizagem da vida pública". Salvo exceção, o pai já não participava diretamente e recomendava o filho a algum ancião notável, próximo da família (PEREIRA, 2002), que gozasse de experiência e das honras que a idade proporcionava. Findo o ano de tirocinium fori, propriamente dito, sem que isso afetasse a continuidade da "aprendizagem da vida pública", o jovem engajavase no exército (MELO, 2007, p. 8).

Marrou (1990, p. 364) ilustra essa etapa de formação com o exemplo da aprendizagem de Cícero, a qual seu pai confiou a Q. Múcio Cévola Áugure, genro de Lélio, um dos sobreviventes da tradicional geração dos Gracos. O jovem Cícero apegou-se a ele, aproveitando toda ocasião para instruir-se. Desse modo, jovens nobres procuravam seguir os passos de políticos experientes. No caso de Cícero, sua permanência ao lado de Cévola Áugure estendeu-se até a morte de seu formador: "[...] depois, jamais considerando sua formação como concluída, passou a ser dirigido por um primo do seu primeiro mestre, Cévola, o Grande Pontífice". (MARROU, 1990, P.364). Há, de fato, grande destaque para o "mérito da velhice, de sua experiência e de sua sabedoria" (MARROU, p. 365): o jovem aristocrata romano termina sua formação ao lado de uma alta influência considerada digna de veneração pelos cidadãos.

Rousseau, claro e pontual em suas referências históricas como forma de reforçar seu pensamento, apresenta o perfil de percepção do homem desta república, onde não se sobressaia o indivíduo e seus respectivos nomes, mas o perfil de cidadão compactuado com o todo: "não era Caius nem Lucius; era um romano" (2004, p. 12). Não sem fundamento Emílio é alertado pelo filósofo:

\begin{abstract}
Mas, caro Emílio, que uma vida tão doce não te afaste dos deveres penosos quando te forem impostos; lembra-te de que os romanos passavam da charrua ao consulado. Se o príncipe ou o Estado te chama ao serviço da pátria, deixa tudo para ir cumprir, no posto que te indicarem, a honrosa função de cidadão. (p.702).
\end{abstract}

Marrou destaca o ideal moral romano pautado na formação da consciência da criança ou do jovem, provendo-Ihe um sistema de valores morais e um estilo de vida, simbolizando o ideal da cidade antiga, marcado pela renúncia e pela doação total da pessoa à comunidade: 
Naturalmente o amor à glória não é estranho ao espírito romano, mas a façanha jamais tem aí o caráter de uma gesta individual; está sempre estreitamente subordinada, como por seu fim, ao bem e à saúde públicos. (MARROU, 1990, p. 365).

Esse tema de identificação do cidadão de Roma com seu país tornou-se um dos mais marcantes pontos de influência em sua formação e pensamento. "Conta Rousseau (As Confissões, Livro I) que muito cedo em sua vida percebeu a influência das Vidas de Plutarco e foi inspirado para imaginar-se um parceiro e perpetrador das grandes façanhas narradas nesses livros". (DENT, 1996, p. 197). De fato, essa experiência infantil nunca o deixou, e em seus escritos da idade madura mantém suas constantes menções à Roma como modelo de um grande Estado que consubstancia, tanto em suas instituições políticas quanto nas atitudes e caráter dos romanos, alguns dos mais fundamentais princípios de sociedade civil. Isso devido à força que Rousseau atribuía às instituições no processo de desnaturação em prol da vida no seio de uma unidade comum e compartilhada (ROUSSEAU, 2004, p. 11-12). A educação moral do jovem romano era sustentada por figuras admiráveis oferecidas à sua contemplação: "[...] eram tirados da história nacional, e não da poesia heroica; o fato de muitos destes exempla serem legendários pouco importa: é como históricos que eram apresentados e revividos". (MARROU, 1990, p. 366). Se a antiga educação, à luz de Homero, dava-se pela imitação dos heróis, a romana destaca-se pela imitação dos ancestres e pelos mais velhos (p.368). A observância dos ritos tradicionais, que caracteriza o patriotismo romano, vincula-se ao que se concebe como primordialmente religioso: submeter-se à tradição seria mostra da obediência aos deuses.

O ideal familiar constituía parte do imaginário dos jovens que, diariamente, estavam expostos a esses exemplos presentes no átrio da família, ouvindo continuamente evocar-Ihes à memória: inicialmente de modo inconsciente, depois, paulatina formação de sua sensibilidade e postura sobre certo tipo ideal de cidadão (MARROU, 1990, p. 368), reforçado pelo convívio na comunidade.

No Tratado sobre a Economia Política (2003d, p. 20-21), o genebrino, aotratar da proteção da dignidade do homem a ser assegurada pelo Estado, recorre a referências clássicas, passando pela Macedônia de Alexandre o Grande, argumentando sobre a importância que a vida de um homem tinha: não ousavam matar um criminoso sem que antes pudesse defender-se diante da comunidade. 
Segue explicando que nem mesmo Senado ou Cônsules teriam o direito de condenar alguém sem o encaminhamento de tal processo "No povo mais poderoso do mundo o crime e a punição de um cidadão eram considerados uma calamidade pública. Tão sério parecia derramar sangue por qualquer crime que pela Lex Porcia $^{25}$ a pena de morte foi substituída pelo banimento". Por fim, finaliza sua abordagem enaltecendo o modelo romano:

Tanto nos exércitos romanos como na própria Roma tudo respirava o amor recíproco dos concidadãos, e o respeito pela condição de romano que estimulava a coragem e inspirava a virtude de todos os que tinham a honra de assim qualificar-se. A cabeça coberta do cidadão resgatado da escravidão e a coroa cívica de quem salvava uma vida eram vistos com o maior prazer no meio da pompa dos seus triunfos; e é notável que entre as coroas concedidas como prêmio de ações esplêndidas na guerra, só a cívica e a do general triunfante eram de louros, todas as outras apenas de ouro. Foi assim que Roma cultivou a virtude e tornou-se a senhora do mundo. (ROUSSEAU, 2003d, p. 20-21).

No mesmo Tratado (p. 28-29), Rousseau, ao explicitar a importância de um fundo de recursos para a manutenção de um Estado (segundo o autor, essa seria a iniciativa mais relevante após a instituição de leis no contexto da fundação de uma república) e sua justa aplicação, novamente destaca a devoção dos romanos à causa pública, exemplificando com a descrita atitude de Catão $0^{26}$ que, nas palavras do autor, "levava sempre no coração a causa da pátria; só vivia para ela, e não poderia suportar a idéia de sobrevivê-la"(p. 18):

Após essa formalidade, que torna tais fundos inalienáveis, sua natureza se transforma, e as receitas passam a ser sagradas; aplicálas mal ou desviá-las minimamente da finalidade a que foram destinadas será não só o mais infame dos roubos mas na verdade uma traição. É uma grande desonra para Roma o fato de que a integridade de Catão foi objeto de comentários, e que um Imperador, ao recompensar o talento de um cantor com algumas moedas, considerou necessário observar que o dinheiro provinha dos seus fundos privados, e não do Estado. (ROUSSEAU, 2003d, p. 29).

\footnotetext{
${ }^{25}$ As leis pórcias e valérias foram leis da República Romana. Conferiam aos cidadãos o direito de proteger-se de formas de punição degradantes ou vergonhosas, como a flagelação ou a crucificação. Elas também estabeleceram certos recursos aos cidadãos romanos, como o provocatio ad populum, o direito de apelar aos tribunos da plebe.

${ }^{26}$ Marco Pórcio Catão (234 - 149 a.C.), eleito cônsul em 195 a.C. com Lúcio Valério Flaco. "Rousseau introduz uma oposição célebre entre Sócrates e Catão, preferindo o segundo ao primeiro, o cidadão ao filósofo. Entre as vantagens de Catão está o fato de que tinha uma pátria no 'fundo do coração', enquanto Sócrates tinha o 'mundo inteiro como pátria'"(FONSENCA JÚNIOR, 2003, p.20).
} 
Mais adiante (p. 32-33), o genebrino recupera as vitórias alcançadas pelo exército romano devido à sua bravura e envolvimento patriótico, comparáveis as de Alexandre, conquistadas mesmo que custasse "o sangue a serviço do país, mas nunca em troca de dinheiro". Recorrendo à história, relembra como a prática (iniciada no fim da República) de pagar à infantaria romana, agregando mercenários, recém libertos e trabalhadores rurais, desvirtuou o ímpeto inicial e constituiu uma das principais causas da ruína do Império Romano. Exemplifica com a Guerra Jugurtina ${ }^{27}$, na qual Mário introduziu às legiões membros como os acima descritos. Esses homens formavam tropas regulares que, apesar de aparentemente terem apresentado o intuito de assegurar proteção externa, eram uma ameaça clara aos próprios cidadãos romanos. A retirada de trabalhadores rurais prejudicava a produção, consequência que gerava aumento de impostos para compensar a necessidade de manutenção da demanda. A população demonstrava seu descontentamento e a miséria batia à porta. Devido aos murmúrios, para proteção do Império, a tropa era aumentada. Os mercenários menosprezavam as leis e os romanos, imaginando-se mais dignos por serem mais "seguidores de César do que por defensores de Roma. Como praticavam a obediência cega, suas espadas estavam sempre no pescoço dos concidadãos, preparados para um morticínio geral ao primeiro aceno" (ROUSSEAU, 2003d, p. 33).

Em obra elucidativa, da qual o genebrino se serviu, Os Discorsi- Comentários sobre a primeira década de Tito Lívio (1994), encontramos estudos e observações do secretário florentino Maquiavel sobre os dez primeiros livros do historiador romano Tito Lívio ${ }^{28}$, escrito à luz dos impasses históricos da Itália renascentista. Seu olhar ao passado constituiu-se em uma reflexão analítica sobre a política passada e presente, movimento reflexivo similar a que Rousseau se propõe: o de buscar modelos políticos para delinear um pensamento crítico em relação ao seu tempo (França do século XVIII):

\footnotetext{
27 A Guerra Jugurtina ocorreu entre 111 a. C. a 104 a.C. Envolvendo Roma e Jugurta da Numídia, representou a pacificação romana no Norte da África, como resposta romana à usurpação do trono númida. Jugurta, antigo aliado, subornou a aceitarem a usurpação até o momento que se tornou insustentável e oneroso para os romanos. Enviaram um exército para detê-lo e, após algumas batalhas, Jugurta foi capturado por traição, evento que encerrou a guerra.

${ }^{28}$ Nascido em Pádua em 59 a. C., foi contemporâneo do imperador Tibério. O legado do historiador compreende 142 livros, da fundação da cidade até 9 a. C. Só se conhece o texto integral de trinta e cinco deles.
} 
Com maior espanto ainda vejo que, nas causas que agitam os cidadãos e nos males que afetam os homens, sempre se recorre aos conselhos e remédios do antigos. As leis, por exemplo, não são mais do que sentenças dos jurisconsultos pretéritos, as quais, codificadas, orientam os modernos juristas. A própria medicina não passa da experiência dos médicos de outros tempos, que ajudam os clínicos de hoje a fazer seus diagnósticos. Contudo, quando se trata de ordenar uma república, manter um Estado, governar um reino, comandar exércitos e administrar a guerra, ou de distribuir justiça aos cidadãos, não se viu ainda um só príncipe, uma só república, um só capitão, ou cidadão, apoiar-se no exemplo da Antiguidade. (ROUSSEAU, 2003d, p.17).

Em seu artigo Maquiavel versus Rousseau: as divisões sociais e seu papel em uma República bem-ordenada, Renato Moscateli (2015) destaca a importância das relações de conflito entre os grupos sociais como temática para a filosofia política, apresentando-nos como Maquiavel, em seu exercício reflexivo sobre o caso da Roma Antiga, explica os embates entre nobreza e plebe como eventos que desencadearam em leis favoráveis à liberdade. Ao nos determos às observações feitas por LeducFayette (1974, p.114), temos clara a noção de um dos mais fundamentais traços de Roma para Rousseau: a liberdade, vendo nos romanos modelo de homens livres. Este termo, para o genebrino, indica submissão às leis. Isso porque é considerado que as leis justas emanariam da razão, e que a obediência à razão seria a expressão mais bem-acabada de liberdade.

Nós pensamos, por nossa parte, que se trata aí, já o dissemos, de uma liberdade nominal: aquela de dizer sim ao bem! (....) a diferença entre Roma e Esparta, se se pode seguir Rousseau, é sobre este ponto que "Sempre prestes a morrer por seu país, um Esparciata amava tão ternamente a pátria que teria até mesmo sacrificado a liberdade para salvá-la. Mas nunca os romanos imaginariam que a pátria poderia sobreviver à liberdade". (ROUSSEAU ${ }^{29}$ apud LEDUCFAYETTE, 1974, p.114).

Segundo a Leduc-Fayette, 1974, p.103-105, assim como seus contemporâneos, o genebrino sofreu uma clara influência de Tito Lívio. Mesmo considerando seus equívocos a respeito dos fatos romanos e à imagem mítica propagada, o fenômeno ético, alicerce da Roma republicana, mobiliza Rousseau e o impressiona. É, sobretudo, ético o arquétipo romano. Esse modelo, historicamente

${ }^{29}$ ROUSSEAU, J-J. Political Writings. Cambridge Universrity Press, 1915, 2 vol. p. 543, 
prodigioso, associa os cidadãos ao império da virtude e ao cultivo da felicidade arregimentada pelo bem público. Leduc-Fayette (1974, p. 106) defende que o mito romano é, primordialmente, um mito ético. Para o genebrino, assim como para Platão, Aristóteles e Montesquieu, ética e política não se dissociam no direito. Dessa forma, o exemplo romano demonstraria a possibilidade da união entre ética e política.

Tal como Moscateli afirma, Rousseau, apesar de embasar-se em Maquiavel com certa regularidade, sobretudo no Contrato Social, apresenta discordâncias e distorções no que tange à interpretação da função política dos conflitos sociais.

No quarto capítulo da primeira parte de Discursos sobre a primeira década de Tito Lívio, Maquiavel detém-se ao tema das dissensões internas como ramificação fundamental para a compreensão da história de Roma e a constituição das suas instituições políticas. O florentino defendia que tais conflitos entre patrícios e plebeus encaminharam a república romana à perfeição, considerando sua estabilidade ao longo de um vasto período:

Como se tratava de um corpo político bem-ordenado, cujos cidadãos possuíam uma grande virtù nascida da boa educação, os tumultos eram capazes de dar origem às leis garantidoras da liberdade (...) assim como ocorreu na rebelião que levou à criação dos tribunos da plebe. Para Maquiavel, os desejos dos povos livres, tais como os da plebe romana, dificilmente são perniciosos para a liberdade, pois eles vêm da suspeita de que se está sob o risco de cair na opressão. No caso do conflito que resultou na instituição do tribunato, o autor afirma que ele foi de grande auxílio para a república, ao dar à plebe sua parte na administração pública, bem como por ter constituído bons guardiões para a liberdade. (MOSCATELI, 2015, p. 122-123).

Maquiavel, portanto, compreendia a política como um campo no qual a ordem e a desordem podiam coexistir e desenvolver uma relação intrínseca. O historiador ressalta como os embates internos da república romana agregavam para a liberdade, justamente por ocorrerem em um ambiente propício, o qual dispunha de instituições legítimas e respeitadas pelos cidadãos. Estas instituições "permitiam aos grupos em disputa canalizar seus anseios sem colocar em risco o próprio sistema". (MOSCATELI, 2015, p. 123). A alteração dos humores não representava um perigo à ordem porque encontravam meio de desafogo em aparatos legais.

Rousseau, apesar das ressalvas em suas interpretações ao florentino, demonstrava publicamente sua admiração por ele, considerando-o bom cidadão e 
defensor da liberdade e da República, em um período de opressão pelo governo dos Médici.

\begin{abstract}
É provável que Rousseau tenha lido Maquiavel durante o período de sua colaboração com os enciclopedistas. Além de sua influência na Economia Política, há traços presentes no Discurso sobre a origem da desigualdade [...]. O nome de Maquiavel também aparece na Rainha Fantasiosa [...], uma obra à qual Rousseau referiu-se como 'uma ninharia' [...]. Há também outra possibilidade - a de que Rousseau poderia ter lido Maquiavel ainda quando estava vivendo em Genebra, durante sua infância. As obras de Maquiavel podiam ser encontradas na pequena biblioteca dos artesãos de Genebra que viviam próximos da família de Rousseau e com os quais ela tinha boas relações [...]. Também sabemos que, entre 1610 e 1650, cinco edições das obras de Maquiavel foram impressas em Genebra ${ }^{30}$ (VIROLI apud MOSCATELI, 2015, p. 124).
\end{abstract}

No Contrato Social (2003), podemos observar a influência de Maquiavel ao tratar o predomínio da vontade geral nas decisões públicas, possibilitado pelo conhecimento prévio das propostas pelos cidadãos, que se comunicavam e informavam antes de alguma proposta ser votada. Rousseau destaca o perigo das facções ou associações parciais como ameaças ao processo deliberativo, fazendo com que cada membro deixe de votar segundo a perspectiva do bem comum e acabe por enaltecer o que é melhor para a associação particular da qual faz parte. O genebrino reconhece que algumas divisões possam beneficiar, bem como a impossibilidade de o fundador de uma república evitar inimizades, desde que não se tornem facções danosas ou associações parciais (grupos com interesses próprios), as quais prejudicam a autêntica enunciação da vontade geral.

Para o florentino, no entanto, diferentemente de Rousseau, é pouco plausível a existência de uma república dotada de unidade, tal como defende o segundo. Sendo os embates inevitáveis, seria necessário que se manifestassem de modo positivo: na medida em que os cidadãos competem por representação em sua associação, tendo em vista a via pública, isso poderia promover "a exaltação da pátria e faz com que uns observem a conduta dos outros e mantenham suas querelas dentro dos limites da ordem civil" (MOSCATELI, 2015, p. 126). Para o florentino, por mais pobre que seja um Estado e por mais modestas que sejam as recompensas, não se deveria

${ }^{30}$ VIROLI, Maurizio. Jean-Jacques Rousseau and the "well-ordered society". Tradução de Derek Hanson. Cambridge: Cambridge University Press, 2002. 
deixar de concedê-las. Premiar a bela ação adquiriria, aos olhos de quem a recebe, um valor de alto impacto simbólico, respaldado na virtude e na vinculação à pátria (MAQUIAVEL, 1994, p. 89). No quesito reconhecimento patriótico, Rousseau novamente aproxima-se de Maquiavel:

Gostaria que todas as virtudes patrióticas fossem glorificadas por meio de honrarias e recompensas públicas; que os cidadãos se mantivessem ocupados com a pátria, mantida permanentemente diante dos seus olhos, e vista como o seu interesse mais importante. Teriam assim menos tempo e oportunidade de enriquecer, e também menos desejo e vontade, aprendendo a conhecer outros prazeres além dos proporcionados pela riqueza. Esta é a arte de enobrecer os espíritos e de transformá-los em um instrumento mais poderoso do que o ouro. (ROUSSEAU, 2003a, p. 232).

O fim da república romana justifica-se na concordância de Rousseau e Maquiavel no que diz respeito às facções, tal como aconteceu na incessante disputa por terras ${ }^{31}$ entre os cidadãos romanos que culminou em guerras civis de grupos opostos, contexto que também encaminhou a tirania de Júlio César. Tais dissensões foram resultado do constante alvoroço causado quando se colocava em pauta a discussão sobre a necessidade de uma lei agrária. Esta lei apresentava dois pontos principais: a delimitação de um máximo de terra que cada cidadão poderia possuir; e o fundamento de que as terras conquistadas aos inimigos deviam de partilhadas por todo o povo romano. Naturalmente, essa demanda da população atingiu os interesses dos nobres e proprietários de terras. (MAQUIAVEL, 1994, p.122).

O ódio entre patrícios e plebe se instaurou e nefastos confrontos se seguiram, liderados por Mário e Sila em um primeiro plano e César e Pompeu em outro. Tais dissonâncias extremas resultaram na perda sem precedentes da conquistada liberdade romana. Essa extrema segregação partidária inviabilizou a promoção de um acordo pelo poder público. Como os magistrados não encontravam mais meios para corrigir a desordem instalada, cada um foi em busca de um líder que representasse

\footnotetext{
${ }^{31}$ A disputa por terras estava intrinsicamente vinculada à expansão militar e territorial de Roma. Fato curioso e de sucesso é que os romanos respeitavam e acatavam às divindades dos novos territórios dominados, não interferindo nos costumes da região em que estivessem se estabelecendo: "Antes de capturar uma posição os romanos pediam aos deuses do lugar que a abandonassem; e quando deixaram que os moradores de Taranto mantivessem seus deuses iracundos foi porque naquele momento os romanos os consideravam seus súditos e, portanto, se sentiam obrigados a render homenagem àquelas divindades. Permitiam aos vencidos manter os seus deuses, como também as suas leis, e muitas vezes se limitavam a cobrar como tributo uma coroa de ouro para Júpiter do Capitólio" (ROUSSEAU, 2003a, p. 233).
} 
seus interesses. Em meio aos distúrbios, o povo dirigiu-se a Mário e elegeu-o cônsul quatro vezes. A nobreza, por sua vez, procurou Sila, "cumulando-o de favores e tomando-o como líder":

Estourou a guerra civil; o sangue correu em torrentes e, depois de muitas vicissitudes, a nobreza alcançou a vitória. Essas comoções agitaram de novo a república nos tempos de César e Pompeu, quando o primeiro era chefe do partido de Mário, e o segundo, do de Sila. A vitória sorriu então a César, que foi o primeiro tirano de Roma, cidade que nunca mais voltou a ser livre. (MAQUIAVEL, 1994, p. 122).

Em lugar de evitar a opressão do senado, "o povo desejou ele mesmo oprimilos, ultrapassando assim as características de seu humor específico e instaurando um desequilíbrio bastante perigoso nas relações de força" (MOSCATELI, 2015, p. 127).

Enquanto o conflito permanece de tal modo que o povo consegue deter a tendência dos grandes ao exercício da dominação ilimitada e os grandes são capazes de impedir o povo de estabelecer uma situação de absoluta liberdade, ele engendra um vivere civile; quando, porém, um humor chega até o seu próprio termo e se completa plenamente, ou quando um humor renuncia à sua singularidade para colocar-se no lugar do outro, transforma seu objetivo último e se identifica com o humor oposto, a Cidade é atravessada por um conflito de natureza diversa, que, em vez de engendrar um vivere civile, na realidade o destrói. (AMES, 2008, p. 53).

A manutenção das liberdades de uma república entre homens de virtú dependia da natureza das divisões atrelada à vigilância mútua, em que um conflito saudável era possível e cujo objetivo era a manutenção do bem comum. (MCKENZIE, 1982). A discordância entre Rousseau e Maquiavel inicia-se quando o genebrino defende a capacidade dos cidadãos tomarem decisões fora de grupos, insistindo na união geral das vontades dos cidadãos. Não se pode ignorar que tal convergência prevista pelo filósofo, reside na importância do papel do legislador, cuja função imbricaria na sensibilidade de perceber e executar a vontade do povo.

Essa imagem de comunhão entre os membros do pacto, "unidade política como sinal de saúde do Estado" (MOSCATELI, 2015, p. 130), representa para Rousseau um quadro ideal diante do qual se poderia julgar as diversas práticas políticas. O enfraquecimento da união de um Estado abriria margem à influência de 
interesses particulares. Tal percepção estaria fundamentada na noção de que o pacto social é a lei constituinte, a qual pressuporia consentimento de todos (os que não o aprovassem estariam excluídos por origem da comunidade política): qualquer consentimento ou lei que se seguisse dependeria da difusão do bem público como real preocupação entre os membros.

Quando se propõe uma lei na assembleia do povo, o que se lhes
pergunta não é precisamente se aprovam ou rejeitam a proposta,
mas se estão ou não de acordo com a vontade geral que é a deles;
cada um, dando o seu sufrágio, dá com isso o a sua opinião, e do
cálculo dos votos de conclui a declaração da vontade geral. Quando,
pois, domina a opinião contraria à minha, tal coisa não prova senão
que eu me enganara e que aquilo que julgava ser a vontade geral,
não o era. Se minha opinião particular tivesse predominado, eu teria
feito uma coisa diferente daquela que quisera; então é que eu não
seria livre. (ROUSSEAU, 1978, p. 120-121).

Se a vontade geral não se configurasse na vontade de todos, para a existência de um Estado bem-ordenado, precisaria ser pelo menos do desejo de quase todos para que fosse legítima. Para regulamentar os aspectos fundamentais do sufrágio, Rousseau defende que quanto mais importante fossem as deliberações, tanto mais o parecer vencedor deveria estar próximo da unanimidade. Nos casos em que fosse necessário rápido retorno à sociedade, o genebrino mostra-se flexível: bastaria a diferença de um voto.

Podemos observar um exemplo da execução da vontade da maioria em menção que Rousseau faz na Economia Política sobre recolhimento de impostos:

[...] fica claro que essa avaliação precisa ser voluntária para que seja legítima; deve depender, portanto, não de uma vontade particular, como se fosse necessário obter o consentimento de cada indivíduo, para que cada um só contribuísse com o que quisesse, mas sim da vontade geral, decidida por voto majoritário, com base na distribuição proporcional que tira da imposição tributária o caráter arbitrário. (ROUSSEAU, 2003d, p. 34)

Para Rousseau, plebeus e patrícios, que disputavam a prevalência de suas díspares opiniões, vistos por ele como dois "Estados", desgastavam o campo político e perturbavam as assembleias populares. Apesar do desfecho político, o filósofo apropria-se de Roma republicana como governo exemplar pela concordância interna entre os plebeus que reinava nos tempos áureos da república, possível de ser vislumbrada nos plebiscitos que na época ocorriam. 
Tal coisa parecerá menos evidente quando duas ou mais ordens entram na sua constituição, como em Roma os patrícios e os plebeus, cujas querelas frequentemente perturbaram os comícios, mesmo nos melhores tempos da Republica. A exceção, porem, é mais aparente do que real, pois então, pelo vicio inerente ao corpo político, tem-se por assim dizer dois Estados num só; o que não é verdadeiro para os dois em conjunto, é verdadeiro para cada um separado. E, com efeito, até nas épocas mais tempestuosas, os plebiscitos do povo, quando o senado não se imiscuía, decorriam sempre tranquilamente e com grande pluralidade de sufrágios: os cidadãos não tendo senão um interesse, o povo não tinha senão uma vontade (ROUSSEAU, 1978, p. 119).

Ao argumentar sobre a degeneração do governo no Contrato Social, percebese sua visão sobre o desenvolvimento da política romana, depois da expulsão dos reis e instauração da república. Em sua perspectiva, pairava uma certa instabilidade devido à disputa de poder entre aristocracia e as demandas democráticas da população. Com a criação dos tribunos da plebe, a forma de governo teria se fixado em uma verdadeira democracia. Nesse período, o povo seria soberano. No entanto, o poder paulatinamente teria sido usurpado, na medida que a aristocracia foi se concentrando no senado e os plebeus teriam afrouxado a condução dos negócios públicos:

O tribunato, sabiamente temperado, representa o mais firme apoio de uma boa constituição, mas, [...] Degenera em tirania quando usurpa o poder executivo, de que é unicamente moderador, e quando quer outorgar leis que apenas deve proteger. [...] Roma pereceu ainda pela mesma via, e o excessivo poder dos tribunos, usurpado grau por grau, serviu, por fim, com o auxílio das leis feitas para a liberdade, como salvaguarda dos imperadores que a destruíram (ROUSSEAU, 1978, p. 132).

Seguiram-se guerras civis, no último século a. C., as quais desencadearam no poder monárquico e, por fim, no despotismo de Tibério.

Rousseau, com sua própria leitura da contribuição de Maquiavel, aponta-nos, adicionalmente, uma percepção relevante na qual destaca o papel crucial dos tribunos da plebe na manutenção da república nos tempos de equilíbrio político, de como esta esfera emanava seu poder, poderio este considerado legítimo por excelência por proceder do povo e de sua consonância interna. Por outro lado, reconhece que a unanimidade por existir de modo invertido: quando se dá sob o jugo dos imperadores e nada resta aos cidadãos senão consentir. 


\subsection{A função formativa do censor romano}

$\mathrm{Na}$ república romana, o cargo de censor representava o último degrau das honrarias públicas, um verdadeiro coroamento conferido a uma trajetória política exemplar. Uma de suas mais simbólicas e fundamentais funções era a de examinar as condutas dos cidadãos. Catão teria exercido com esmero o cargo de censor romano, atuando firmemente contra o luxo aumentando, por exemplo, os impostos dos proprietários. Medidas como essa justificavam-se, segundo Plutarco, na afirmação que "o desejo de riquezas não se prende a nenhum de nossos sentimentos naturais, mas vem de fora, vem da opinião alheia!"32 (PLUTARCO apud Silva, 2003, p. 157). Sua atuação contava com o apoio popular: símbolo disso foi a estátua erguida em sua homenagem no templo de Higeia, com dizeres gravados que, para além de enaltecer sua condução no redirecionamento da república romana e sua temperança, assumia-o como instrutor (o mais simbólico termo gravado).

A exemplo de seu bisavô, como salienta Silva (2003, p. 157), Catão de Útica (95-46 a. C.) foi um cidadão-modelo. Ao contar sua história, Plutarco ${ }^{33}$ remonta à época em que Catão de Útica investia contra a tirania de César, vislumbrando um cenário de guerras civis em que grupos favoráveis ao tirano e grupos favoráveis a Crasso e Pompeu instigaram os cidadãos a conflitos, o que teria desolado Catão. Após ter garantido a fuga de senadores e outros cidadãos de Útica, em jantar com amigos declarou sua intenção de suicidar-se.

Ao vincular a política à ética, Rousseau exige mais que o cumprimento das leis. Exige que a obediência à vontade geral parte de uma vontade ética. Catão de Útica encerra esse ideal (...). A virtude política praticada pelos grandes modelos de cidadãos romanos é a virtude do amor pela res publica. (SILVA, 2003, p. 160).

Para Leduc-Fayette ${ }^{34}$, Catão de Útica representa uma trajetória política semelhante a de Sócrates, figura que surge em um momento pós apogeu

\footnotetext{
32 PLUTARCO. Marco Catão. In:

Paulo: Paumape, 1991. v. 2. p. 286. Vidas Paralelas. Tradução de Wilson César Cardoso. São

${ }^{33}$ Plutarco, adicionalmente, nos deixou como legado a obra "Catão de Útica", a partir da qual Fábio de Barros Silva (2003), traz alguns apontamentos.

${ }^{34}$ LEDUC-FAYETTE, Jean-Jacques Rousseau et le mythe de l'antiguité.
} 
republicano, marcado por oscilações seguidas da queda, configurando-se em símbolo da virtude e do patriotismo romanos: "Catão encarna a figura do cidadão que se sacrifica pela pátria" (SILVA, 2003, p. 160). Em face à tirania, assume uma resistência ímpar como defensor exemplar da república, representando o povo oprimido. Para Silva (2003, p.106), esta figura política encerra o ideal rousseauniano "que a obediência à vontade geral parta de uma vontade ética", a partir de um patriotismo visto como paixão paulatinamente cultivada na res publica, orientando os cidadãos à prática do bem comum, conforme ratifica Leduc-Fayette.

\begin{abstract}
A luta de Catão, sintetiza a atitude de Rousseau diante do luxo e do cultivo das ciências que, ao invés de aprimorar os costumes, conduziram os homens à decadência, à queda. Ao lado do patriotismo, a frugalidade é um dos traços que Rousseau mais admira na Roma Republicana. Outro traço importante a ser salientado é o fato de que Roma é vista como símbolo da liberdade, na medida em que obedecer às leis que emanam da razão é ser livre. Desobedecer significa tornar-se escravo dos instintos e, consequentemente, dos vícios (SILVA, 2003, p. 161).
\end{abstract}

Vemos que essa liberdade, a que poderemos considerar liberdade civil para o sentido a que Rousseau atribui, constitui-se em um movimento do cidadão em direção aos seus compatriotas, que reverbera para si na vida pública diariamente exercida. Por meio da ressignificação de seu sentido, pois essa liberdade é cotidianamente vivida nas festividades, eventos, no âmbito familiar e em outros episódios simbólicos; os cidadãos romanos apropriam-se dela como via de felicidade, felicidade esta que reside na promoção e preservação do bem comum. Como recorda Silva (2003, p. 162), Rousseau resgata a exemplar figura de Catão, o censor, ao tratar dos deveres da família para com os filhos, que incluem a participação ativa na educação dos que um dia se tornarão cidadãos do Estado. Ser livre é uma conquista e um compromisso moral, pois requer o exercício dos talentos em prol da comunidade, depende do legado deixado pelos mais velhos e do cumprimento do dever dos mais jovens de perpetuar essa liberdade.

O autor afirma que, para Rousseau, o bom cidadão não se inclina para a vaidade, pois opta pela virtude, pela coragem moral e pelo amor à pátria, como representa a figura de Catão: "Ele representa a própria virtude cívica e a vontade geral" (SILVA, 2003 p. 80). O referencial teórico do modelo de Roma em Rousseau é parte de um apelo à vida política virtuosa (por esse motivo trata-se de virtude cívica), 
que busca clarificar os caminhos do homem em sociedade imerso na contradição e no dilema de atender às suas paixões e cumprir seus deveres como cidadão. 


\section{PARTE II: ROUSSEAU E O REPUBLICANISMO}

\section{ORIGENS DO REPUBLICANISMO: O CAMINHO ATÉ A REVOLUÇÃO FRANCESA}

O período que antecede a denominada Revolução Francesa foi marcado por graves problemas internos na sociedade francesa nas áreas social, econômica, política e financeira. Por um lado, havia a monarquia, a nobreza e o clero, encabeçando a hierarquia social do país, sustentadas em seus direitos e privilégios e, de outro, a nascente burguesia e a grande população que vivia dos campos trabalhando em sua maioria em terras pertencentes à nobreza (SILVA, 2011, p.121).

Dividindo a população em três segmentos, essa estrutura direcionava o poder à nobreza e ao clero, os quais dispunham de benefícios e honrarias que sobrecarregavam o terceiro estado (camponeses e burguesia ascendente). Somado a essa conjuntura desfavorável para a maior parte da população, a qual gerava a inquietude subsequente, o alcance dos ideais iluministas, caracterizados pela valorização da razão, cercou-se das condições que precisava para a Revolução. O rompimento com a monarquia absolutista resultou em transformações nos aspectos político e social que embasaram a partir da criação de leis uma reconfiguração das relações entre as várias camadas sociais e projetos diversos (políticos, educativos e relativos ao voto).

Estes ideais já advinham das mudanças trazidas a partir do século XVII, agregando novas percepções ao pensamento europeu e amadurecendo suas ideias. Sinteticamente, o lluminismo abraçava a prática da livre iniciativa no âmbito econômico, a liberdade de pensamento e a igualdade de todos os homens ante a Constituição. Portando-se como porta-vozes das Luzes, os intelectuais dos vários campos do saber, iluministas, dedicavam-se "ao cultivo das ciências e das letras no século XVIII"35. A relação entre eles "produzia uma sociabilidade inédita; traduzida pelo cultivo de um ambiente cultural, a um só tempo, humanista, artístico e científico"36. Ademais:

\footnotetext{
35 BOTO, 2017, p. 180.
}

${ }^{36}$ BOTO, 2017, p. 180. 
Existe uma concepção otimista de mundo; que faz crer que os progressos da razão são os progressos da ciência e das técnicas. Assim, tende-se a acreditar que o presente é melhor que o passado, e que o futuro será melhor que o presente, como se houvesse um movimento na história que tende ao aperfeiçoamento. (BOTO, 2017, p. 179-180)

Dentre os homens de letras, Rousseau foi um dos poucos que não se identificavam com essas noções de progresso. Opondo-se a essa concepção, para o filósofo, o traço que distinguia o homem não residia em um caminho em direção ao progresso, mas a perfectibilidade, sendo este o potencial humano de se tornar melhor para si e para os que o cercam. Apesar de postular a favor dessa capacidade, o genebrino posiciona-se de modo cético, pois acredita que essa prédisposição não é garantia de sucesso. Vinculando sua teoria política a sua visão pedagógica, Rousseau defronta o problema da civilização: "Toda a obra rousseauniana ancora-se em uma veemente crítica ao processo civilizador moderno. Mesmo assim, a esperança de regenerar a vida social e civil está contida em todo seu pensamento" 37 . Pensar de modo diferente em relação aos seus contemporâneos associa-se ao modo como Rousseau entende a civilização, sobre a qual julga que, ao contrário de aprimorar os costumes, corrompeu-os. Isso se deveria à saída do estado de natureza ao estado civil, passagem na qual, desvirtuando-se, o homem em sociedade começa a pautar sua existência na defesa do direito de propriedade. Diante desse cenário, restaria firmar um novo contrato social, capaz de ressignificar a vida civil e, ancorado na ideia de virtude, assegurar os direitos dos membros do corpo político.

O mundo greco-romano, por seus marcantes valores e figuras históricas, serviu de inspiração para a Revolução Francesa. Grande parte dos que estavam à frente da Revolução (sobretudo intelectuais da "época das luzes") acreditavam que o legado deixado por alguns dos mais reconhecidos nomes da Antiguidade Clássica como Tito Lívio, Plutarco e Cícero, possuía consideráveis recursos a serem apreendidos pela França em transformação, desejosa de mudança e insatisfeita com as instituições monárquicas: "as grandes ideias das Luzes não tiveram sua origem no século XVII; quando elas não vieram da Antiguidade, elas trouxeram traços da Alta Idade Média, da Renascença e da época clássica"38 (TODOROV apud BOTO, 2017, p. 181). Desse modo, o projeto das Luzes representava recapitulação e

37 BOTO, 2017, p. 182.

38 TODOROV, T. L'esprit des Lumières. Paris: Robert Laffont, 2006. 
síntese históricas, articulando novas perspectivas.

De um lado, pensadores que pareciam recuperar a herança greco-romana de forma idealizada e praticável, de outro, intelectuais que a viam como pouco possível ou de difícil execução, uma vez que, na percepção deles, uma república só seria realizável em Estados pequenos, pois uma extensão mais notável representaria riscos visíveis de fracasso, tal como ocorrera em Roma. No entanto, novos e esperançosos ares cercavam o fim do século XVIII:

\begin{abstract}
A declaração da independência dos Estados Unidos da América veio provar-Ihes da possibilidade de uma república num Estado de área extensa; os acontecimentos de 1789, além de Ihe revigorarem de novo a esperança de verem a França com instituições e costumes semelhantes aos da Antiguidade Clássica, ofereceram-lhes ocasião de porem em prática as reformas que há muito lhes viviam na mente. (FERREIRA, 1988, p. 209).
\end{abstract}

No plano dos acontecimentos da Revolução, verificavam-se propostas que continham elementos greco-romanos, perpassando as Assembleias Constituinte e Legislativa. A criação do tributado, vinculado à história romana; os festivais desportivos e a forma de educação aludiam, com reservas, à Esparta. De Roma, vai se buscar uma perspectiva dos tempos gloriosos de República, sua organização e equilíbrio políticos, cujas virtudes (diligência, autodomínio, justiça, coragem e liberdade) fundamentavam e sustentavam o amor à pátria. De Esparta, o anseio por igualdade, relembrando os Homoioi, em tempos em que todo cidadão dispunha de uma parcela de terra.

Essa herança histórico-cultural em muito marcou a tríade do pensamento base (igualdade, liberdade e fraternidade) da Declaração dos Direitos do Homem e do Cidadão (1789). Essa Declaração, que tinha Rousseau como um dos seus mais importantes inspiradores, exaltava: a Liberdade, indicando a não interferência da autoridade nos interesses privados (o que não representa uma ideia e preocupação puramente rousseaunianas, já que para Rousseau, a liberdade compreendia, sobretudo, a manutenção da soberania nas mãos do povo); Fraternidade estabelecendo uma comunidade solidária formada por indivíduos iguais e livres, e Igualdade representando a ausência de privilégios entre os homens. Tais ideais ainda hoje produzem efeitos sobre a elaboração dos mais diferentes processos democráticos e legais por todos os continentes: 
O pensamento de Rousseau foi precursor dos chamados direitos fundamentais, ou primários, em função dos quais decorrem todos os outros. Deles podem-se enumerar 0 direito à vida, ao nascer livre e igual, ao direito de propriedade, de liberdade e de segurança, independentes de qualquer fato ou circunstância histórica. (SILVA, 2011, p. 125).

Com o intuito de destrinchar a temática a qual se propõe, como apresenta o título de seu livro: "As aventuras da virtude - As ideias republicanas na França do século XVIII", Newton Bignotto perpassa pela Revolução Francesa. Esse marco histórico, associado à época das "Luzes" foi, como resgata o autor, levado efetivamente a cabo pela maior parte da população francesa que, por sua vez, não era letrada, já saturada das injustiças e infortúnios advindos da Monarquia. Com as novas demandas políticas, os intelectuais começaram a apropriar-se e produzir sobre o que estava acontecendo.

O considerado republicanismo da Revolução não foi produto direto desse período histórico, mas resultado de um vasto repertório que já estava à disposição nas décadas anteriores a 1789 , nas quais se delineava uma nova cultura política. Após a queda do Antigo Regime, já há tempos desgastado, foi uma solução pensada para as necessidades da época. Montesquieu, nesse sentido, exerceu papel fundamental na formação desse arcabouço teórico, do qual puderam se apropriar de tópicos fundamentais, tal como o da autoridade arbitrária, vícios do governo, defesa da liberdade, independência dos parlamentos e tolerância às crenças religiosas, entre outros, ajudando a forjar uma linguagem teórica política moderna e lutando contra as diferentes formas de despotismo, como destaca Bignotto. O filósofo e político francês procura explanar a relevância da virtude cívica, da virtude na República, destacando o amor à pátria e à igualdade como molas que movem o governo. Esses pontos de sua teoria e de sua ligação com o republicanismo, recebe críticas atuais a respeito do que é entendido por essa visão como "virtude dos antigos", a qual estaria, para os críticos, calcada no heroísmo e irrealizável nas sociedades capitalistas. Segundo Bignotto, este entendimento seria refutável na medida em que não é proposto um modelo de ação tal como na Antiguidade, sem as devidas reservas e apropriações.

A República, por sua vez, não se trata do resultado direto de uma virtude intangível, 
mas "define um campo de organização do poder a partir da ideia de distribuição do poder do soberano" (BIGNOTTO, 2010, p. 38). A vida em comum na política moderna é pautada na manufatura e no comércio, ao passo que para os antigos, apoiava-se na virtude. Tal constatação, no entanto, não representa, aos olhos do autor, uma incompatibilidade entre os dois universos. Opô-los seria afirmar que comércio é o oposto da virtude. Para os antigos, a virtude representa uma inclinação aos interesses da coletividade, cujas relações regulavam-se a partir dessa noção. Montesquieu entende que sacrificar o indivíduo pela pátria não cabe à França do século XVIII, demarcando os limites que entendia para a virtude, de modo a não comprometer a liberdade:

Aos olhos de Montesquieu, a equação da virtude política torna-se
mais complexa na medida em que seu termo principal se desdobra
no interior do mesmo agente. O cidadão e o indivíduo são partes do
mesmo sujeito, mas não é mais possível esperar que os interesses
decorrentes do fato de sermos membros de uma comunidade política
sejam sempre coincidentes com aqueles que nos dizem respeito
como indivíduos. Virtude e liberdade passam a constituir um par
inseparável e dinâmico que aponta para o caráter do regime
republicano e seus limites. (BIGNOTTO, 2010, p. 54-55).

A respeito da função do exemplo histórico em Rousseau e Montesquieu, temos uma diferença entre ambos, sobre a qual o próprio Rousseau posicionava-se criticamente em relação a Montesquieu. Para o genebrino, o direito determina e avalia a política diante da História, sendo o exemplo histórico um conselheiro. Para Montesquieu, arraigado na História dos fatos, interessa o desencadeamento das cenas históricas e suas causalidades.

Moscateli (2009) destaca a importância das obras de Montesquieu para a elaboração da teoria política de Rousseau. Apesar de suas diferenças, Rousseau não ignorava a história: tinha consciência da importância do conhecimento histórico acumulado para um consistente posicionamento teórico:

Contudo, a leitura de seus textos mostra também que é muito útil conhecer o que existe para julgar o que deve ser, não porque neles o direito seja deduzido dos fatos, mas porque as experiências vividas pelos povos historicamente forneceram ao filósofo elementos para 
pensar sobre qual é a justiça possível neste mundo. (MOSCATELI, 2009, p. 319).

Em suas reflexões, Rousseau incorporou o discernimento proveniente de Montesquieu a respeito da influência das múltiplas causas que influenciam os povos, dentre eles os fatores físicos e morais, aparecendo os primeiros como causas que determinam a ação do homem selvagem e os morais que, após a formação das sociedades mais complexas, aparecerem como fatores determinantes.

Diferentemente de Montesquieu, para Rousseau, o olhar ao passado ocupava uma centralidade única como recurso para avaliar o presente, elencando critérios que poderiam legitimar ou invalidar os Estados existentes. No entanto, a temática da degeneração de um corpo político era comum a ambos, que apesar das especificidades de suas interpretações, viam no exemplo romano parâmetro de compreensão de como a corrupção moral e a decadência da política podem culminar na dissolução de um Estado.

Segundo Moscateli (2009), Montesquieu, que denota uma teia realmente elaborada de causalidade para lidar com a compreensão da história, é um teórico da História dos processos e das estruturas, o que permitiram a ele a formulação de problematizações como pilar para a investigação histórica. Ao se tratar de objeções liberais ao retorno do republicanismo, temos as visões de Thomas Hobbes (15881679) e Norberto Bobbio (1909-2004), citados por Bignotto (2010), os quais consideram que as ações republicanas contrariam os impulsos naturais dos homens, opondo a natureza humana à pratica da virtude. Bignotto (2010, p. 43) ressalta, em contraponto a essas objeções, a função do Estado ideal como parte da vida política, guiando as ações humanas: "basta que seja possível aos olhos de quem o deseja". O ideal republicano seria, desse modo, uma ferramenta analítica para as ações. O fato de os membros atuais de uma sociedade não agirem em plenitude de acordo com a virtude republicana, não inviabilizaria a realização processual de um Estado republicano. O mundo das representações configurar-se-ia em parte essencial da vida política. Com base nessa assertiva, Bignotto entende que Montesquieu tem consciência das dificuldades de se realizar os princípios republicanos. Por esse motivo, vê com pessimismo a sua efetivação em vastos territórios.

A educação, para Montesquieu, dispõe de parte fundamental na realização desses princípios citados anteriormente. "Aliás, elas só podem ocorrer 
num pequeno Estado, onde se pode dar uma educação geral e educar como uma família todo um povo" (MONTESQUIEU ${ }^{39}$ apud BIGNOTTO, 2010, p. 47).

Bignotto (2010) afirma que a hipótese inicial de sua obra As aventuras da virtude baseia-se na ideia de que, para compreender um governo republicano, é necessário compreender a virtude. A virtude republicana sustentar-se-ia no amor pelas leis e pela pátria, abrangendo a supremacia do interesse público. Para Montesquieu, o amor à pátria é pensado como sentimento, não como conhecimento. Não se trataria de exigir cidadãos extraordinários, mas homens capazes de amar a igualdade. A função dos governantes residiria no fomento da república, semelhante ao modo como Aristóteles vislumbrava o alcance do governante: sua condução refletiria diretamente na politeia e nos cidadãos.

Newton Bignotto destaca o lugar fundamental de Montesquieu na constituição da matriz francesa do republicanismo, ao contribuir para a criação de um vocabulário próprio para se pensar a virtude republicana na modernidade, discutindo conceitos como liberdade e igualdade em um cenário em que não eram claros temas envolvendo dimensões do território, virtude e bem comum, relação entre cidadão e Estado.

Em capítulo dedicado à virtude e política em Rousseau, BIGNOTTO (2010, p. 86-136 relembra de Genebra como cidade republicana modelo, enfatizando como o filósofo orgulhava-se em ter sido nela criado. O movimento teórico de retornar ao passado para explorar e buscar referências de temas republicanos já tinha seu lugar desde o Renascimento, onde o retorno à história antiga representava um recurso de questionamento à tirania e à exaltação de formas livres de governo. O elogio aos regimes de Esparta e Roma, em contraponto com as monarquias europeias, constituía uma comparação com os predecessores italianos Petrarca, Cícero e Tito Lívio, por exemplo, ajudando a compor o desenvolvimento do chamado humanismo cívico.

Rousseau recorria a essas referências históricas com "filtro" republicano, servindo-se de elementos essenciais que fortalecessem sua filosofia política. Essa inclinação teórica, no entanto, não colocou o filósofo em posição idealista no que tange à apropriação desses elementos em formas de governo contemporâneas a ele: “...] o desejo de viver em uma república virtuosa e harmônica nunca escondeu

${ }^{39}$ MONTESQUIEU. Considérations sur les cause de la grandeur des romains et de leur décadence. In Oeuvres completes. Paris: Gallimard, 1951. Vol II. p. 270. 
suas dúvidas quanto à possibilidade de sua realização em sua época". (BIGNOTTO, 2010, p. 88).

Plutarco e seus grandes personagens históricos foi, adicionalmente, uma leitura que Rousseau apreciava desde pequeno. Sua crítica à corrupção dispunha de referências a Platão, Sêneca, Homero, Ovídio, Aristóteles e Lucrécio.

Algumas características de Esparta serviram de base para o desenvolvimento da teoria de Rousseau. A comunhão cívica entre cidadão e Estado, a aversão ao luxo e à ostentação, em contrapartida ao estilo de vida almejado pelo cidadão francês de sua época, a simplicidade, a frugalidade, a liberdade e a igualdade são alguns exemplos de conceitos fundamentais para Rousseau.

Tito Lívio, outra importante referência de Rousseau, tem em destaque a frugalidade e o devotamento à coisa pública, bem como o amor à pátria como pilares de sua obra, que percorre a república romana. A virtude cívica e a liberdade como valor último, representam outros importantes aspectos da apropriação rousseauniana da referência romana.

Bignotto (2010, p.88) observa que o elogio da conduta moral de Esparta e Roma somado às críticas de seu tempo abriu possibilidades para a crítica da obra rousseauniana, entendendo-a como precursora dos totalitarismos contemporâneos. Os críticos consideravam que a disciplina espartana seria uma forma de corrigir os costumes corrompidos do século XVIII, como uma simples transposição histórica. Leduc-Fayette (1974) fala em "virtualidades totalitárias" evidentes em Rousseau. A autora reforça a importância de compreender a relação que Rousseau estabelece com o passado, com a História. Dialoga reiterando suas reservas a respeito da obra do autor e seus riscos totalitários, considerando Esparta uma cidade com inclinações totalitárias. Bignotto questiona se o termo totalitário remete, necessariamente, à tirania. E se remete, caberia indagar porque Esparta nunca foi considerada historicamente uma cidade que atentasse contra a liberdade, ou uma tirania:

Se não for esse o caminho, caberá então à intérprete mostrar como as cidades antigas podiam ser totalitárias sem ser tirânicas e, sobretudo, em que bases essa afirmação poderia ser feita, pois é reconhecido o fato de que as fontes históricas para o estudo de Esparta são raras e muitas vezes misturadas a uma visão mitifica do funcionamento da cidade (BIGNOTTO, 2010, p. 92). 
Desenvolver a relação de Rousseau com o republicanismo não é um processo simples, pois não se trata, apenas, da admiração pelos lacedemônios, por exemplo, e sua transposição para outra realidade, como observam os críticos de Rousseau. Parcela das críticas, comenta Bignotto, foi alavancada pelo uso que Robespierre, líder dos jacobinos, fez das obras do filósofo durante o Período do Terror na Revolução Francesa, entre 1793 e 1794.

Outro elemento da crítica trata-se da imagem do "corpo uno" o que, não é suficiente para compreender um regime totalitário. Newton Bignotto afirma que tal representação não tem, necessariamente, seu fim em um regime como o acima citado, mas é uma possibilidade inscrita em as sociedades que lutam para afirmar suas identidades. Resgata a compreensão de Hannah Arendt dos regimes totalitários, os quais se fundamentariam na extinção da experiência política, o que não tem lugar na filosofia ou nos objetivos teóricos de Rousseau, ao utilizar os referenciais clássicos.

A chave para entendimento dessas inclinações teóricas está em investigar como as referências a Esparta e Roma e sua apropriação pelo filósofo relacionam-se a outros elementos essenciais do pensamento de Rousseau, transitando a uma ponte em que alguns eixos da Antiguidade Clássica servem para a construção de seu ideário republicano. Constitui-se em uma inspiração e em uma estratégia para reforçar suas principais ideias e para demarcar a Antiguidade em seu pensamento.

O lugar da Antiguidade, em Rousseau, é bastante recorrente no Primeiro Discurso, no qual, em resposta à Academia de Dijon, o autor discorre sobre o papel das ciências e das artes na depuração ou corrupção dos costumes. Obra em que se pode identificar ressalvas do autor aos iluministas e o modo como desenvolve seu pensamento a respeito de dois principais temas: a Antiguidade e a virtude.

Borges Júnior (2015) comenta sobre a ascendência moral atribuída por Rousseau sobre os costumes dos modernos, discorrendo a respeito do dever moral pressuposto na guerra: a guerra não é feita para ser um ofício do homem, mas para defesa de sua liberdade- significar morrer, se preciso for, servindo à pátria:

As virtudes guerreiras, portanto, não devem ser concebidas a partir de sua característica comumente acompanhada, a coragem. Pelo menos não a coragem cega e que, em última instância, se apresenta como uma obediência inveterada aos comandos do rei, ou ainda uma obediência aos seus próprios grilhões, isto é, a algo de belo na guerra e nos combates é essencialmente a defesa da liberdade de 
seus concidadãos e, por fim, a defesa do bem público representado pela Pátria. (BORGES JR, 2015, p. 101).

Agir virtuosamente em uma república, afirma o autor, é a verdadeira honra que um particular pode almejar, colocando-se a serviço do concidadão e de sua pátria. Não basta dispor das virtudes, é preciso coloca-las em ação.

Em resposta ao Sr. Bordes, presente no Discurso sobre as ciências e as artes, pode-se novamente observar uma valorização por parte de Rousseau à frugalidade e às funções representativas dessa sobriedade de hábitos, como a de lavradores, de caçadores, de pastores e, com as ressalvas acima comentadas, a de soldados. Em outro momento do Discurso, ratifica-se a crítica às artificialidades humanas, quando se desprendem dos aspectos essenciais à manutenção da comunidade:

O luxo pode ser um sinal certo de riquezas, pode até mesmo servir, caso se queira, para multiplicá-las; mas que se deverá concluir desse paradoxo tão digno de haver nascido em nossos dias? E o que será da virtude, quando for preciso enriquecer a qualquer preço? Os antigos políticos falavam incessantemente de costumes e de virtude; os nossos só falam de comércio e de dinheiro ${ }^{40}$. (ROUSSEAU apud BORGES JR., 2015, p. 108).

Uma exemplar menção de Rousseau a episódios ilustrativos de devoção à pátria encontra-se na Roma antiga, protagonizado por Lúcio Júnio Bruto, renomado cônsul romano (séc. VI a. C.), que ao ver-se em situação de decidir por salvar a república, o que implicaria no sacrifício dos filhos, opta pela pátria. Com sua decisão, Bruto coloca o bem comum acima de suas inclinações individuais (BORGES, JR., 2015, p. 119-120): "[...] o que fica evidente a partir desse exemplo é que a força da alma e o heroísmo que a acompanha são essenciais em tempos cuja oportunidade de se assegurar o bem comum e os interesses da pátria são fugidios". O Primeiro Discurso de Rousseau representa a mais notável crítica ao encaminhamento das sociedades modernas, que subjuga as necessidades coletivas e os valores patrióticos. Essa carência republicana, percebida pelo genebrino, o mobiliza no resgate aos exemplos dos antigos:

40 ROUSSEAU, J-J. Discours sur les sciences et les arts. Introd. et commentaire George R. Havens. New York: Modern Language Association, 1946, p. 19. 
[...] como se nota no Discurso sobre as ciências e as artes, ao explicitar uma objeção ao modelo vigente em seu contexto a partir de uma exaltação ao arquétipo espartano, permitindo uma confrontação entre ambos. A imagem gloriosa da Antiguidade em Rousseau amiúde vem acompanhada de uma máxima acerca da degeneração moderna e resvala em uma justificação da virtude antiga em comparação ao domínio da decadência em seu tempo. Não nos cabe aqui julgar se Rousseau adere completamente ao modelo espartano. Mas pode-se supor que ele se utiliza de referências antigas para questionar os regimes políticos modernos e expressar sua insatisfação com eles. (ALVES, 2017, p. 95).

Alves comenta a predileção de Rousseau por Esparta quando comparada a Atenas pelo fato da segunda ter se tornado rica e comercial, observando no pensamento rousseauniano uma vigorosa crítica ao desejo de enriquecimento, advindo "das operações mercantis e fomentadoras da criação de inúmeras necessidades supérfluas" (ALVES, 2017, p. 97). Segundo o genebrino, essas necessidades fariam de nós escravos. Os espartanos, por outro lado, cultivavam a simplicidade e a frugalidade. Rousseau se servirá do modelo espartano para elaborar duras críticas ao gosto pelo luxo, tão presentes no século das Luzes.

Essa contraposição a Atenas, optando por Esparta, explica Leduc-Fayette (1974, p.75-76), reflete um julgamento de que a primeira representaria a civilização a se corromper, segundo sua avaliação que o cultivo das ciências e das artes é acompanhado da perda das virtudes éticas e militares.

Dentre os indicativos do estado de corrupção nas sociedades, Rousseau destaca, por exemplo, o que chama de perda das "amizades sinceras", por ter a ideia de sinceridade como ponto de destaque em sua filosofia. Considera-se, nesse aspecto, questionamentos voltados às máscaras sociais de seu tempo, temática está igualmente presente na obra "A Nova Heloísa" (1994) ${ }^{41}$. Neste seu escrito, é possível identificar a síntese entre as esferas privada e pública, ao tratar da vida interior do protagonista e seus dilemas existenciais. Não seria apenas a escolha da montanha que o protegeria dos males da civilização, afastando-se da sociedade. Os obstáculos são maiores e mais complexos: trata-se da capacidade, do

\footnotetext{
41 Lançado em 1761, a obra apresenta elementos de muitas de suas obras, como do "Contrato Social" e do "Emílio", como afirma Milton Meira do Nascimento em seu texto "A transparência dos corações"(1996). Além disso, engloba reflexões diversas sobre temáticas como teatro, botânica, religião e o costume dos povos. Retrata o amor entre Saint-Preux e Júlia, um professor de filosofia plebeu e uma aristocrata, bem como os dilemas provenientes dos preconceitos e da força da tradição da vida em sociedade os quais, muitas vezes, sucumbem os mais profundos sentimentos naturais.
} 
discernimento, de exercitar a liberdade que se tem dentre as possibilidades em que é colocada. As ações virtuosas dependeriam de um esforço, um trabalho interior.

Bignotto aponta que não se pode ignorar a dimensão utópica de Rousseau: há, sim, o ideal de pequenas comunidades, o desejo de estabilidade e da realização plena das potencialidades humanas. Apesar dessa dimensão, é um guia para se pensar questões republicanas fundamentais.

Sua defesa vai ao encontro dos sentimentos vinculados ao exercício da razão, da consciência, para trilhar o caminho em busca da verdade, em contrapartida às abstrações ligadas à metafísica, as quais recebem sua crítica. Não é por acaso que o filósofo confronta Esparta e Atenas, destacando Esparta como "espadada" a provocar seus contemporâneos, como cita Bignotto ao referir-se à autora Judith Shklar, em Men and Citizens ${ }^{42}$. Esparta representa, para Rousseau, um ideal de vida totalmente oposto ao que parecia dominar as sociedades mais avançadas, seja do presente ou do passado.

Rousseau, ao considerar a simplicidade e rusticidade dos costumes como fatores essenciais para a promoção de uma coesão social e estabilidade das instituições, utiliza esses referenciais históricos como crítica ao luxo e à vaidade.

A obra do Primeiro Discurso é um convite a sair do quadro de referência tradicional e da Filosofia das Luzes, a qual centraliza a ideia de progresso por meio do conhecimento e das Ciências. Para o autor, este progresso não contribui na compreensão da natureza humana e afasta os homens das virtudes que mantiveram as cidades antigas em momentos de dificuldade.

Em suas considerações finais, Borges Júnior (2015) aponta, para além da crítica aos Impérios e às monarquias no Primeiro Discurso, o aspecto moral advindo de relações intersubjetivas em que a opressão "[...] surge da consciência, da opinião que o indivíduo tem sobre si e sobre aqueles que o circundam" (BORGES JR., 2015, p. 122). Abordando a problemática dos costumes, é colocado em pauta o lugar do homem na sociedade e na natureza. O autor enfatiza que o Primeiro Discurso não tem, de modo algum, o intuito de depreciar a trajetória de conhecimento humano. Para além da redução da influência das ciências e das artes a um certo moralismo, registram-se as consequências morais e políticas vislumbradas por Rousseau,

42 A citada obra tem sua primeira publicação datada de 1969. É considerada um dos melhores estudos da teoria social de Rousseau. Shklar examina umas das principais preocupações do filósofo que, diante da impossibilidade de retorno do homem ao seu estado de natureza, indaga-se como poderia readequar a existência humana na vida em sociedade. 
considerando a diminuição das ações virtuosas e a contração da esfera pública diante dos interesses individuais: o parâmetro positivo de Rousseau é "[...] uma organização social em que a virtude é garantia da liberdade e projeto de uma sociedade mais igualitária". (BORGES JR., 2015, p. 125) .

Na supracitada obra, é desvelado por Rousseau o uso político das ciências e das artes, segundo afirma Borges Júnior, destacando o trecho em que o genebrino afirma que as ciências e as artes consolidaram os tronos anteriormente erguidos por "necessidade".

Rousseau, ao nomear "felizes escravos", representa a condição do homem moderno em que se enaltecem por serem "déspotas esclarecidos". Ao se orientarem para conhecimentos inúteis, as ciências se associam às artes e tornam os homens mais propensos à servidão. (BORGES JR., 2015, p. 126).

Rousseau difere de Montesquieu no quesito relações comerciais e inclinações virtuosas, criticando-o no tema em destaque. Montesquieu aceita a possibilidade de particulares disporem de riquezas sem a corrupção dos costumes, indicando que não existiria uma incompatibilidade entre virtude e o espírito do comércio. Vincula-o às virtudes como a frugalidade, moderação e sabedoria, sem deixar de destacar ressalvas no que diz respeito aos excessos:

Esta aproximación encarna una inflexión central en el texto: se trata
de la introducción de un juicio positivo respecto del hecho comercial,
que pasa a ser convergente con ciertas virtudes. Recordemos que,
tradicionalmente, el comercio había sido visto en cierta tensión con la
moralidad y el bien humanos. 3 En todo caso, estas "virtudes
comerciales" permiten que las riquezas no produzcan malos efectos:
las fortunas son inofensivas si estas disposiciones son conservadas.
El mal llega, prosigue nuestro autor, cuando el exceso de riquezas
"destruye este espíritu de comercio", lo que implica que haya alguna
antinomia entre ese espíritu y las riquezas. Sabemos entonces que
hay un equilibrio que debe ser protegido, en ausencia del cual estas
virtudes pueden perderse. (MANSUY, 2016, p. 219).

A vida política constitui um tema central no pensamento de Rousseau. Ao tratar de virtude cívica, convida o leitor a refletir sobre o relacionamento do cidadão com as questões do Estado e com suas instituições políticas. O autor aponta para a relevância da concessão das vontades individuais à vontade geral, quando se trata de um cidadão que percebe o sentido da sua vida inscrito na vida comunitária. Não é sem objetivo que Rousseau recorre a Plutarco e a seus heróis cívicos, ao tratar da 
vida virtuosa que os cercava, com base no desenvolvimento das qualidades cívicas. Para além do que pode ser considerada submissão do cidadão ao Estado, trata-se de um movimento de adesão consentido e claro, motivado pelo amor à pátria e ressignificado pelo desejo de manutenção de vida do homem.

Rousseau, de modo muito próximo aos humanistas, percebeu no espaço público, lugar ideal para a prática das virtudes, vislumbrando um cidadão ativo para uma vida política ativa. Tal colocação fica nítida em Economia Política, obra que auxilia no entendimento da esfera política. Na cidade, o homem daria vazão aos seus potenciais sociais e conquistaria o terreno para o exercício de sua liberdade. Por esse motivo, adicionalmente, Rousseau nos remete ao mundo antigo para reforçar o apelo à ação, o que difere em absoluto da defesa de formas autoritárias de governo.

Em Rousseau, não há sentido único para a virtude. Virtude cívica, por exemplo, refere-se à relação estabelecida entre o homem e a vida pública, à liberdade política e à esfera social. O homem consigo mesmo, a consciência individual e a liberdade de consciência, bem como a esfera privada, vinculam-se à virtude moral. Apesar de diferenciarem-se, não são incompatíveis na filosofia do autor.

Aos críticos que questionam em Rousseau a simples conformidade do homem à comunidade política em que está inserido, Bignotto reforça a importância do "fórum interior" (p. 122) na relação com a virtude e, posteriormente, com o próximo e com a comunidade (virtude cívica), lembrando-nos do caráter intersubjetivo do ato cívico e do enraizamento da moralidade. Pode-se considerar que se trata de um movimento de respeito à identidade, constituído tanto socialmente quanto na relação do homem consigo mesmo, ao que se chama de virtude moral. Esta última necessitaria da liberdade de consciência para se realizar. A virtude cívica, por sua vez, vincula-se à liberdade política. Ambas as liberdades estariam conectadas para a promoção da vida política tal como Rousseau a considera.

O ideal ocupa um lugar no pensamento de Rousseau abarcando a totalidade da experiência humana (considerando a virtuosidade dos cidadãos), não apenas estagnando no terreno da organização institucional: "Uma vez perdida a simplicidade inicial da vida isolada, o indivíduo tem de lutar para encontrar o espaço de realização de sua liberdade e tornar-se virtuoso" (BIGNOTTO, 2010, p. 113). Esse seria um dos 
principais pontos para a vida virtuosa, na qual o respeito ao exercício da liberdade do outro é parte constitutiva, compõe a perfectibilidade acentuada no Segundo Discurso. Essa faculdade de se aperfeiçoar não apresenta, no entanto, um sentido definido:

É por isso que seu desenvolvimento pode ocorrer para o bem ou para o mal, e, nesse sentido, acarretar um verdadeiro progresso ou uma exasperação da corrupção do homem, no momento em que este empreende o processo de sociabilidade. (BECKER, 2008, p.185).

O curso da história não permite mais a liberdade natural, tal como na vida do homem anterior à comunidade, mas a cívica que é a possível, pode ser aproveitada em plenitude, em um ambiente político que a favoreça.

Apesar de suas abstrações, os escritos de Rousseau permitem a identificação de seu pessimismo. Mesmo ao apontar caminhos desejáveis, ideais, tem claro para si a corrupção de sua época e a compreensão de que o processo histórico não pode ser detido. A obra Cartas da Montanha, considerada um escrito rousseauniano que contrapõe ideias utópicas (ao defender, por exemplo, as pequenas repúblicas) e apresenta uma dimensão crítica de sua análise. Adicionalmente, Rousseau adverte:

Explora-se com erudição na obscuridade dos séculos, passeia-se
com fausto nos povos da Antiguidade. Apresentam-se
sucessivamente Atenas, Esparta, Roma, Cartago; joga-se nos olhos
a areia da Libia para impedir-vos de ver o que se passa sob vossos
olhos. (ROUSSEAU ${ }^{43}$ apud BIGNOTTO, 2010, p. 118).

Mais uma vez aparece claramente a crítica do autor ao declínio moral das sociedades que observava na época em que vivia. Não deixa de ser um alerta para que se evite um entendimento equivocado de suas intenções teóricas: enaltecer os referenciais de governo passados não teria sentido sem uma reflexão de teor crítico do curso atual da história em que se vive. O recurso à utopia em Rousseau seria, então, um recurso que permite ao leitor medir a distância entre as potencialidades da natureza humana e sua condição atual.

A crítica a sua época vai de par com a consciência de que os homens são a um só tempo prisioneiros de sua natureza e da relação que têm com a história, a qual os afasta continuamente de suas qualidades primeiras. A corrupção inevitável das instituições é o

${ }^{43}$ ROUSSEAU, J.J. Lettres écrites de la Montagne. In Oeuvres completes. Paris: Gallimard, 1964. Vol. III. 
pano de fundo sobre o qual todas as formas politicas evoluem. Deixá-las de lado implica perder-se nas brumas de um ideal que, por si só, não é capaz de frear a marcha inexorável da história. (BIGNOTTO, 2010, p. 120).

Genebra $^{44}$ é vista como cidade ideal para compreensão da origem da desigualdade, observando o equilíbrio conquistado entre "a ordem pública e a felicidade dos particulares".

Como propôs Baczko, a combinação perfeita para entender Rousseau está entre utopia e revolta. A cada vez que ele propõe um modelo ideal, uma realidade muito precisa é visada - e é objeto de uma crítica feroz. É com essa ferramenta que nos propomos a estudar os dois modelos de comunidade [Genebra e Clarens]. (BIGNOTTO, 2010, p. 114).

Bronislaw Baczko, em Lumières de l'utopie, explora o lugar fundamental da liberdade na lei e na filosofia política de Rousseau. Não se trataria de uma obrigação, mas de uma inclinação sustentada pela própria consciência do cidadão. Não teria como, então, desvincular liberdade cívica do conceito de virtude: "Tomando esse ponto de partida, compreendemos que a questão da virtude é um derivado do problema dos fundamentos da política, e não o seu eixo". (BIGNOTTO, p. 159). A preocupação do genebrino, ao tratar de virtude, direciona-se à manutenção do pacto social, da sobrevivência e significado do Contrato, bem como do vínculo que os cidadãos estabelecem com a legislação a qual aderiram voluntariamente por meio do pacto.

Em Rousseau, não basta resumir sua teoria política indicando sua preferência por Esparta ou por uma comunidade doméstica. Resumi-la, incorre-se na perda da percepção que, na aspiração por um mundo melhor, nunca perde de vista os efeitos nefastos da corrupção sobre a vida dos homens. Em outras palavras, o retorno à Antiguidade é um modo de o filósofo demonstrar seu ceticismo em relação às reais condições de sua época.

À guisa de fechamento do capítulo, é relevante ressaltar que se procurou percorrer pelo legado greco-romano, perpassando pela Revolução Francesa que fortemente o considerou nas figuras de importantes pioneiros, por conta dos

\footnotetext{
${ }^{44}$ Mesmo Genebra, tão aclamada pelo autor, acabou representando não apenas um ideal, mas "a prova viva do poder da corrupção" (BIGNOTTO, 2010, p. 114), que se perdeu no jogo de interesses e luta pelo poder.
} 
frequentes apontamentos relativos a este legado nos escritos do genebrino, apresentando exemplos ilustrativos da admiração que o autor sustentava por essa página da história e pela sua capacidade de constituir, a partir de características formativas no seio da própria pátria, uma profunda identificação patriótica voltada ao bem comum.

Pode-se dizer que todo aquele que se viu influenciado por Rousseau, sejam os membros do Círculo Social ou mesmo os jacobinos, ao se apropriarem de sua obra, cada qual com seus objetivos específicos, direta ou indiretamente, lidam com um repertório embasado, em muitos aspectos, nos referenciais da Antiguidade.

\subsection{Enciclopédia e a formação do léxico republicano}

Iniciada em 1751 e finalizada em 1772, a Enciclopédia, concebida por Diderot e D'Alembert, pode ser considerada o projeto editorial mais ambicioso e influente dos pensadores do lluminismo, o qual pode contar com cento e sessenta colaboradores diretos. Representa o projeto iluminista do progresso da humanidade no saber e da crença na razão. Por conter muitos ataques às principais ideias fundamentais do Antigo Regime, em pouco tempo assumiu fama de subversiva, como é possível observar no verbete dos padres. Parte do processo de criação de uma nova linguagem para se pensar o mundo, a Enciclopédia colaborou na constituição do republicanismo francês.

O verbete sobre república, elaborado por Jaucourt ${ }^{45}$, apresenta crítica sobre a viabilidade desse sistema de governo em territórios extensos, citando Montesquieu. Sobre esse aspecto, como comenta Bignotto, a maior parte dos pensadores do século XVIII apresentavam a mesma opinião a esse respeito. Adicionalmente, embora com ressalvas, Bignotto menciona Veneza e Holanda como exemplos da manutenção dos princípios republicanos em territórios maiores. A potência soberana estaria com o povo ou parte dele. Tal como em Rousseau, Genebra é exaltada como exemplo moderno destacando, com igual importância, os modelos antigos.

Ademais, explicita como, apesar de para muitos ser considerada uma experiência do passado impossível de ser reproduzida na modernidade, a república

\footnotetext{
45 Louis de Jaucourt (1704-1779) foi um erudito francês e um dos mais reconhecidos intelectuais que
} contribuíram para a Enciclopédia. 
e sua matriz teórica francesa foi tão evocada e debatida entre os revolucionários:

A nosso ver, o interdito lançado contra a república na modernidade, ou melhor, sua restrição a pequenos territórios, não impediu o desenvolvimento de um léxico conceitual que serviria de base para as discussões posteriores. $\mathrm{O}$ verbete que estamos analisando [0 verbete da república] comprova essa tese (BIGNOTTO, 2010, p. 59).

Com o intuito de afirmar os princípios do governo republicano, Jaucourt recorre à referência histórica dos gregos. Comenta o declínio ateniense, ao paulatinamente corromper seus costumes e abandonar o amor à pátria. De modo semelhante, menciona a decadência de Roma, ao permitir ruir os princípios republicanos à arte militar voltada ao incansável desejo por conquistas. A ambição dos particulares expandiu-se igualmente, em detrimento do desprezo pelas riquezas e o amor pela glória e pelo bem comum:

[...] o esquema analítico usado para o estudo de Roma é o mesmo que o de Atenas: passa pela afirmação de que a corrupção de uma república é a corrupção de seus princípios e de que a expansão territorial tem um papel determinante nesse processo". (BIGNOTTO, 2010, p. 60).

Diante da ideia de um governo misto como estratégia para inviabilizar a corrupção no sistema, as repúblicas federativas, emergem como uma possibilidade de transposição para as necessidades mais práticas da vida política. A partir de reflexões advindas da obra Considerações sobre o governo da Polônia, Nicholas Dent explicita como as dificuldades procedentes das dimensões de território extensas e da dispersão da população podem ser transpostas de modo a não comprometer o processo de formação da identidade nacional e de amor pela pátria.

Para resolver essa dificuldade, ele advoga o princípio de federação, como sendo desenvolvido na época pela Confederação de Bar. A federação habilitará as pessoas a manter um forte e palpável sentimento de vida comum em suas localidades, ao mesmo tempo que coordenam seus objetivos para proteção comum sob uma constituição central. (DENT, 1996, p. 81-82).

Jaucourt, ao resgatar o papel da participação dos cidadãos na vida pública, reforça a tradição republicana a respeito dessa temática. Para isso, é destacado o 
lugar da virtude na vida do cidadão, do qual se esperaria, em uma sociedade republicana democrática, a capacidade de "amar as leis, a pátria, a igualdade e a frugalidade". (BIGNOTTO, 2010, p. 64). Sobre esse aspecto, o autor resgata o ataque dos críticos liberais, os quais consideravam inviável tais práticas, uma vez que entravam em conflito com o leque de interesses individuais.

No verbete virtude, Ramilly pontua elementos morais, religiosos e políticos, alargando a definição elaborada. Define a virtude como conceito ligado aos deveres do homem e como um sentimento que atinge todo o ser. Pensa-se como um fato da consciência que, para além do eixo individual, planifica-se e realiza-se na ação de impacto coletivo. Newton Bignotto, compondo sua crítica à filosofia de Hobbes e ao ceticismo de Bayle, afirma que a virtude constitui os parâmetros das instituições políticas, contribuindo para o desenvolvimento das potencialidades humanas: "[...] as representações intelectuais do século XVIII, incluindo as de Rousseau, as de Diderot e mesmo as de um aristocrata como Voltaire, insistiam na virtude cidadã como base do governo não tirânico". (ROMANO ${ }^{46}$ apud BOTO, 2017, p. 239).

A ausência de virtude constituiria o campo de batalhas no qual os indivíduos digladiam-se por seus interesses particulares. Desse modo, virtude garante a referência ao bem comum e unifica o homem ao Estado, diferentemente da corrente liberal que, paralelamente, defendia a autorregulação do mercado como força civilizadora e libertadora.

A Enciclopédia e seus verbetes, representam um espaço fundamental de consolidação e fermentação de questões que contribuíram com o debate posterior sobre a natureza do republicanismo, constituindo uma preparação do seu léxico.

Voltaire e sua filosofia republicana apresentou-se na Enciclopédia como outra grande contribuição para o supracitado léxico, colaborando na "lenta erosão do edifício monárquico em todos os seus fundamentos". (BIGNOTTO, 2010, p. 67-68). Apesar de ter apoiado governantes contrários às novas mudanças que se mostravam necessárias, a monarquia como sistema de governo seria, na sua concepção de república, inconcebível.

Décadas antes da Revolução, os temas do republicanismo foram aos poucos impondo-se. A decisiva contribuição de Voltaire, como destaca Bignotto, foi o elogio

46 ROMANO, Roberto. Mentiras transparentes: Rousseau e a contrarrevolução romântica. In: MARQUES, José Oscar de Almeida (Org.). Verdades e mentiras: 30 ensaios em torno de JeanJacques Rousseau. ljuí: Unijuí, 2005. p. 22. 
ao governo da Inglaterra e crítica incisiva aos costumes franceses. Em suas Cartas filosóficas $^{47}$ enfatiza, dentre outros aspectos, o mal da atuação do clero na vida pública. Investiga e analisa os quakers ${ }^{48}$, seita ilustrativa que se opõe em elementos fundamentais ao catolicismo, dentre outras seitas, comparando-as com a religião católica:

\begin{abstract}
A preparação daquilo que ele considera um processo extremo de desenraizamento dos franceses de suas tradições políticas e religiosas só pôde ser conduzida porque na França os intelectuais foram capazes de transmitir suas críticas à religião a todas as camadas da população. (BIGNOTTO, 2010, p. 71).
\end{abstract}

O começo da Revolução Francesa tinha a Inglaterra como modelo de governo livre e tolerante, abarcando uma multiplicidade de posições. O catolicismo, por sua vez, é sentido como nocivo e contrário ao bem público. Voltaire retoma com veemência a denúncia que procedia desde o Renascimento, a qual vincula religião e poder nas sociedades, bem como seu alcance e impacto contrários a um governo livre. Como Montesquieu e Rousseau, apresenta suas reservas em relação à virtude em vastos territórios. Essa virtude, em sua concepção filosófica, estaria atrelada a um significado político e associada a uma consciência cidadã.

No verbete igualdade, novamente observa-se uma visão crítica da sociedade pensada por Voltaire o qual, claramente contra a divisão social entre opressores e oprimidos, reforça a naturalidade da igualdade como direito natural.

\footnotetext{
47 Obra datada de 1734, com o registro das reflexões que o contato com as estruturas e instituições sociais, com a cultura e a vertente religiosa incutiu no autor ainda jovem.

48 Bignotto comenta a ironia utilizada por Voltaire para se dirigir a alguns costumes da citada seita, mas aprecia a recusa e princípios dos membros que a frequentavam em aceitar dinheiro, levar uma vida de luxo ou chamando algum membro de "majestade", além da crítica bem pontuada da divisão de classes.
} 
Após a Revolução Francesa, percebia-se o notável despreparo da sociedade em lidar com a nova situação política posta (ou a ser constituída). Os fundadores do Círculo Social, Bonneville, Fauchet e Mercier, discutiam essa situação e viam, nas ideias de Rousseau, novas possibilidades para a construção dessa realidade que se colocava. Em outras palavras, a sociedade necessitava de um guia conceitual, referenciais de uma "gramática republicana", tal como nomeado um dos capítulos de Bignotto (2010). O Contrato Social, nesse contexto, é umas das principais obras exploradas pelos intelectuais e políticos que se colocavam à frente do cenário francês pós Revolução.

Para Rousseau, o Contrato representa o desejo de fundar uma sociedade republicana legítima, autêntica, sendo que essa autenticidade referir-se-ia diretamente à participação do povo na vida política.

Em Opinião pública e Revolução (2016), Milton Meira do Nascimento discorre sobre as ideias de um grupo de intelectuais revolucionários que exerceram papel marcante no desenvolvimento de uma teoria da opinião pública e na função de preceptores do povo, objetivando o exercício da soberania do povo e a derrubada dos tiranos. Por meio da imprensa, mais especificamente do jornal Boche de fer, "A boca de ferro", colocar-se-ia em vigor um modo de vigilância pública, como explicita Marilena Chauí em prefácio do supracitado livro:

Máquina de mobilização das massas para formar um poder de vigilância pública que garanta a soberania popular, o Círculo Social pretendeu a regeneração da humanidade (...) sob o signo do Verbo Divino criador do mundo e da verdade uma, universal e eterna, capaz de congregar os homens em um pacto social para além das fronteiras nacionais. Autonomeados "Amigos da Verdade e da Justiça". (CHAUÍ, 2016, p. 14).

O jornal representava um instrumento de enaltecimento da liberdade de imprensa e oferecia-se como porta-voz do povo oprimido. A opinião pública, como bem coloca Chauí (2016, p.14), seria "[...] o encontro entre a razão e o povo esclarecido, torna-se lugar da verdade e seu poderio depende de conseguir impor-se aos homens de poder", apresentando a meta de tornar transparente a administração pública. 
A busca por uma universalidade e a uma verdade absoluta no campo da opinião, confere ao Círculo Social um caráter ideológico em sua pretensão. Tal caráter, também presente na condução política dos adversários jacobinos, mostra como uma pretensa verdade que teria nascido do debate de opiniões, sucedeu-se por um governo autoritário que, respaldando-se na vitória de sua opinião, retira dos demais o direto à expressão, conduzindo com tirania e violência seus ideais.

Com "A boca de ferro", Bonneville pretende tornar oficial um instrumento de combate à tirania, estabelecendo um meio seguro para colocar ao alcance do povo, com o mínimo de interferência pessoal, o que chama de uma "verdade pura", conduzindo a nação inteira à ordem da natureza e de um pacto social:

Já nessa proposta de Bonneville, notamos uma assimilação da doutrina de Rousseau, a partir de uma interpretação literal de questões tais como a volta à natureza e a realização de um pacto social. A teoria de Rousseau deve ser simplesmente posta em prática sem nenhum questionamento. Esta, aliás, será a interpretação corrente das obras de Rousseau durante a revolução francesa. Revolucionários e contrarrevolucionários procurarão sempre uma aplicação prática das ideias dos cidadãos de Genebra. (NASCIMENTO, 2016a, p. 87).

Nascimento alerta sobre um elemento que se coloca para além das diferentes leituras e interpretações de diversos autores: " [...] mais do que o conteúdo do texto que se propões a decifrar, revelam acima de tudo suas próprias identidades". (NASCIMENTO, 2016a, p. 164). O autor contextualiza essas reivindicações teóricas de paternidade rousseauniana, à luz do Contrato Social como principal obra, no quadro complexo da Revolução, onde clubes e associações constituem a trama de um embate pelo poder.

Para alguns, Rousseau era autor da Revolução; para outros, defensor da monarquia; antirrousseauístas o identificavam com os jacobinos e como inspirador da época do terror. Essa luta ideológica passa a ocupar diversos espaços, como em jornais e tratados de política.

Anarcharsis Clootz, barão prussiano que chegou a ser deputado da Assembleia Legislativa, é comentado por Nascimento (2016a, p.168) para indicar uma leitura de Rousseau embasada no materialismo e em seu zelo revolucionário, a qual ocasionou a expulsão da sociedade dos jacobinos e à sua condenação à morte 
em março de 1794. O barão colocava-se contra as formas de violência e pregava a união do gênero humano.

Por outro lado, é citado o advogado François Lenormant, para o qual as ideias de Rousseau no Contrato o colocam como aristocrata e primeiro inimigo da Revolução, ao fazer a leitura do que está posto nessa obra sobre a impossibilidade de um governo democrático em um estado grande e sobre a soberania não poder ser representada. As críticas mais contundentes deram-se por ocasião do busto de Rousseau que é posto na Assembleia Nacional ao lado de outros autores de destaque, colocando-o como representante da nação francesa.

Nascimento (2016a, p. 169) explicita que, ao prestar a homenagem a Rousseau, a Assembleia Nacional posiciona o autor em primeiro plano como preceptor da luta pela libertação, citando trecho em que Eymar, deputado de Forcalquier, apresenta uma moção na qual elementos como o ódio do filósofo pela tirania, os direitos do povo oprimido e o amor à liberdade são destacados como foco da solenidade em que Rousseau é posto como representante.

Em um esforço de adaptação do Contrato Social à nova realidade da Revolução, adendos à obra, suplementos, foram elaborados por alguns admiradores, como Gudin de la Brenellerie, defensor da monarquia e membro das academias de Lyon, Marseille e Auxerre, posição política que o obrigou a refugiar-se dos jacobinos na época de perseguição. Outro suplemento com outra vertente teórica foi a elaborada por Fauchet, um dos fundadores do Círculo Social.

Outras leituras da obra de Rousseau também produziram inimigos, como Isnard, que o atacava em seu princípio da soberania como expressão da vontade geral: "O que Isnard propõe é o governo de um monarca único que represente e simbolize a nação e que, em vez de governar segundo a própria vontade, faça da razão a sua lei" (NASCIMENTO, 2016a, p.174).

Nesse movimento de apropriação, outros intelectuais, como Mercier, que chegou a ser preso na época do terror e em período posterior ocupou lugar no Conselho dos 500, elaboram, para além de uma reverência à obra de Rousseau, críticas ao filósofo. Mercier indica, por exemplo, que o genebrino poderia ter sinalizado o direito de insurreição como direito de todo povo oprimido reagir.

Nascimento (2016a, p.174) apresenta ressalvas a Mercier, comentando a dificuldade de antecipar os acontecimentos desencadeados após a tomada da Bastilha. Um ponto fundamental, apresentado pelo autor de $A$ farsa da 
representação política, é o destaque ao acúmulo dos escritos contra a tirania, o qual representava a resistência do povo oprimido ao terem voz por meio dos "homens de letras".

Do mencionado Círculo Social participavam, entre outros, Condorcet, Claviêre e Guy Kersaint. O Círculo, sob o ideal de ecoar a voz do povo ratificando sua força, deixava à disposição dos cidadãos urnas em praças de Paris e em cidades do interior, nas quais o povo poderia depositar suas opiniões e denúncias, bem como propostas à Assembleia Nacional. Como tribunos do povo, os membros do Círculo encarregavam-se da divulgação por meio do seu jornal:

E como era preciso defender o caráter representativo da Assembleia Nacional, Fauchet não hesita em modelar a teoria de Rousseau apresentando o poder da opinião pública como a própria soberania, como uma forma de participação direta nas decisões, sem representação. Desta forma ele permanece ao mesmo tempo fiel aos princípios de Rousseau e ao caráter representativo da Assembleia Nacional. (NASCIMENTO, 2016a, p. 179).

Não poderia deixar de ser comentada, outra vertente de leitura foi a de Robespierre, marcando o ano II da República e um novo estágio das leituras do Contrato. Robespierre, chamado por inimigos de "ditador sanguinário", não escondia sua admiração por Rousseau e mencionava, em vários discursos, o filósofo como ser supremo e digno de culto. Nascimento resgata a narração de um autor anônimo, para relatar um imaginado encontro entre Robespierre e Rousseau. Em festa em sua homenagem, em um "outro mundo", Rousseau, percebendo Robespierre com "boca espumante de inveja" e "semblante totalmente desfigurado", dirige-se a ele e mostra um espetáculo digno de desespero do ditador. Nesse cenário, são projetados os destinos da França reerguida após a queda dos jacobinos. Não suportando o quadro apresentado, Robespierre volta correndo para "viver para sempre na morada dos condenados ao suplício eterno. Recusado por aquele a quem tanto admirava, que vexame para Robespierre!" (NASCIMENTO, 2016a, p. 179).

Por outro lado, temos o Círculo Social, o já comentado grupo de intelectuais revolucionários que estabeleceu uma teoria da opinião pública e a função preceptorial dos intelectuais no decorrer da Revolução, guiando o povo para o exercício da soberania e na destituição dos tiranos, por meio da imprensa vigilante.

Destaca Nascimento (2016b, p. 107), que chega a ser surpreendente a quantia de citações de textos de Rousseau pelos membros do Círculo Social. Ao 
levantar o questionamento "por que Rousseau?", o autor observa que o genebrino não partilhava com a filosofia das luzes, ao não compactuar com o ideal do progresso das ciências como movimento histórico relevante para a promoção da libertação dos povos assumindo, assim, uma visão histórica pessimista. Apesar dessa fundamental ressalva para a compreensão da teoria política do filósofo em questão, Nascimento aponta a possibilidade de uma reviravolta, tal como pode ser identificada no legado de Rousseau:

[...] a catástrofe pressagiada oferece toda a sua magnitude à imagem frágil de uma última chance: num sobressalto coletivo, ou, melhor ainda, conduzidas por um legislador providencial, as sociedades poderiam reencontrar seus verdadeiros princípios: liberdade, igualdade, virtudes cívicas. (STAROBINSKY ${ }^{49}$ apud NASCIMENTO, 2016b, p. 109).

A compreensão do momento único em que viviam em 1789 proporcionaram aos protagonistas revolucionários o sentimento de estarem se reerguendo das cinzas. Nesse sentido, a palavra rousseauniana e a de outros filósofos suscitaram reflexões e ações políticas que encorajaram o desenvolvimento de conceitos, oferecendo uma "[...] linguagem na qual, solenemente e nem sempre com muita clareza, a Revolução iria poder exaltar a si mesma (...)". (NASCIMENTO, 2016b, p. 110-111). Segundo o mencionado autor, a leitura que os membros do Círculo fazem de Rousseau exemplificam uma apropriação otimista da possibilidade de uma conquista plena da liberdade, onde a revolução configura-se como ocasião de regeneração não apenas para o povo francês, mas para todos os povos do mundo.

Os membros do Círculo Social, que viam em Rousseau uma das pessoas excepcionais elencadas pela providência como instrumento de realização desse grande evento histórico, procuravam em sua obra fundamentos teórico-políticos para amadurecimento desse grande movimento revolucionário. Nessa linha e conforme já concebido por Bonneville, o contrato surge como essas soluções últimas em um cenário de crise.

As diferentes assimilações de Rousseau, principalmente ao considerar a apropriação do Círculo Social, demonstram a busca por um preceptor ou inspirador para dar sequência à marcha que segue após a libertação do povo francês.

Para além de uma associação fechada ou franco-maçônica, Fauchet propõe o

49 STAROBINSKY, J. 1789 - Les emblemes de laraison. Paris: Champs-Flamarion, 1979. p. 177. 
prolongamento do que entende como primordial para a sociedade: a propagação da religião do amor em todos os corações.

Rousseau, no quesito representatividade, aceita em sua teoria representação apenas no poder executivo. Assembleias regulares e revogabilidade dos mandatos dos representantes, bem como uma postura vigilante do povo constituiriam estratégias para o correto desempenho das funções do executivo.

O legislador, à parte do corpo político, aparecendo no momento da fundação dos estados, inspirado pelas figuras histórico-míticas de Moisés e Licurgo, protagonizaria a criação das condições para a manifestação da vontade coletiva. A leitura que Claude Fauchet faz para o contexto revolucionário, vê, nos homens de letras, a representação da figura do legislador, homens estes que já estariam trabalhando há algum tempo "[...] para a difusão do saber e a eliminação dos preconceitos e das superstições [...]. Em termos relativos, os deputados constituintes assumem a função dos legisladores". (NASCIMENTO, 2016b, p. 125). Por um lado, a responsabilidade em traduzir em leis os anseios coletivos, por outro, demarcar a identidade de um povo.

No entanto, o distanciamento necessário para a ascensão da racionalidade pura exigida para a promoção da figura de legislador dividia os membros do Círculo Social, especificamente os eleitos Boneville e Fauchet para a primeira comuna de Paris, que intentavam ser os guardiões dos costumes e da opinião pública, o que exigiria o mencionado distanciamento, colocando em questão a execução das deliberações do povo e a participação direta do jogo político e dos princípios do grupo, bem como suas demandas de atuação revolucionária. 
PARTE III: EDUCAÇÃO PARA A CIDADANIA

\section{EMÍLIO E O DILEMA DE FORMAÇÃO: FORMAR O HOMEM OU O CIDADÃO?}

[...] as boas instituições sociais são as que melhor sabem desnaturar o homem, retirar-lhe sua existência absoluta para dar-lhe uma relativa, e transferir o eu para a unidade comum, de sorte que cada particular não se creia mais um, mas parte da unidade, e só seja sensível no todo ${ }^{50}$ (ROUSSEAU apud FRANCISCO, 2010, p. 70)

A eliminação do homem natural ou desnaturação não é, necessariamente, um problema para Rousseau, quando está posta uma sociedade em que o bem comum é o objetivo diariamente buscado pelos cidadãos, quando a vontade geral é respeitada e o amor à pátria é o elemento fundamental na formação dos cidadãos, como é o caso das sociedades-modelo para o autor. Engendrar, primeiramente, a formação do homem natural no Emílio, por exemplo, representa a crítica de Rousseau às sociedades modernas, incapazes, pela corrupção de suas instituições, de desnaturar verdadeiramente o homem, inábeis a oferecer o que prevê o Contrato ou o que advinha das sociedades antigas exemplares, como considera Esparta.

\footnotetext{
Um filósofo superficial observa as almas que foram trabalhadas cem vezes no fermento da sociedade, e pensa ter observado o homem. Mas para entendê-lo bem é preciso desenredar a hierarquia natural dos seus sentimentos e não é entre os habitantes de uma metrópole que devemos buscar os primeiros sinais da natureza impressos no coração humano. (ROUSSEAU, 2003b, p. 58).
}

A análise realizada por Rousseau e sua fundamentação subjacente à ideia de homem natural são elementos que muito colaboram para a compreensão do pensamento e teoria deste filósofo. O homem natural é a representação do homem anterior à sua corrupção, princípio norteador de toda moral sobre a qual raciocinou. Para Rousseau, a corrupção é resultante do progresso dos vícios da vida em sociedade. Assim, todos os vícios percebidos no homem seriam a ele externos, adquiridos, e não naturais. A única paixão que teria nascido com o homem seria o amor de si, a base da piedade natural, qualidade que poderia possibilitar a 
consciência moral e a apreensão das noções de justiça e direito. Pela alteração progressiva de sua bondade inata no convívio social, seriam gerados os conhecidos males:

Ele [Rousseau] persuade o leitor a partir junto com ele num primeiro momento de uma hipótese imaginária acerca de um estado de natureza que admite como passível de nunca ter existido para, através da educação se evitar incorrer no erro de buscar na história o remédio para os males que o homem enfrenta na modernidade. (ARAGÃO, 2008, p.47-48).

No Segundo Discurso e no Contrato Social podemos observar como o homem natural não é pensado como modelo normativo, pois se sabe da impossibilidade de retornar ao estado de natureza. Diante disso, Rousseau parece indagar: como tornar a vida menos miserável, uma vez que o retorno é inviável? Assim, "[...] sendo a vida social um artifício, terá ela de ser criada e pensada segundo critérios morais, os quais não são dados aos homens quando ainda vivem isolados e independentes" (BIGNOTTO, 2010, p. 133). O homem leva para a vida social seu desejo de preservação e seu sentido de independência, por força das necessidades. Desse modo, Rousseau não considera que o homem deva alienar-se completamente das suas inclinações iniciais, mas adaptá-las ou repensá-las, de acordo com a situação que se coloca. Ao comentar sobre as tensões advindas entre o movimento que parte do indivíduo e o contrato social que o homem opta, Bignotto acrescenta:

De fato, os desejos dos indivíduos farão parte das relações sociais, mas é por não poderem ser suprimidos que se necessita de um pacto, e não para satisfazê-los em primeira instância ou para darIhes livre curso. (BIGNOTTO, 2010, p. 144).

O ceticismo de Rousseau o orienta mais para a busca de um equilíbrio, mais para a percepção clara da realidade, que para um ideal irrealizável que custasse a supressão de toda e qualquer inclinação individual. No entanto, a oposição entre indivíduo e cidadão segue sendo uma temática desafiadora na obra de Rousseau. $O$ curso da história segue e formas políticas artificiais colocam-se para ajuste dos indivíduos. O objetivo do Contrato por si só não busca a satisfação plena das inclinações primárias do homem: 
A preferência de Rousseau por certos modelos políticos não apaga a tensão que domina seu pensamento e o fato de que não há instituição política capaz de superar de maneira definitiva a oposição entre cidadão e indivíduo. (BIGNOTTO, 2010, p. 134).

Em seção intitulada "Emílio: categoria operatória e cidadão do mundo" do capítulo "Política e pedagogia na arquitetura ilustrada de Rousseau", Carlota Boto (2017) destaca, no Emílio de Rousseau, a criança retratada como um tipo ideal ${ }^{51}$ "uma categoria operatória"52. A mencionada obra de Rousseau é, segundo a autora, uma busca de entendimento das peculiaridades que caracterizam a ideia de infância, sem o objetivo de estruturar um conjunto de orientações relativos a métodos de ensino. Para além do retrato da infância, Rousseau não elaborou um roteiro sobre o ensino de crianças reais. Trata-se de da construção de hipóteses operatórias como estratégia do genebrino.

Em defesa de sua educação natural, a infância de Rousseau estende-se até os doze anos:

A repercussão que Emílio teve em seu tempo e as apropriações posteriores das ideias pedagógica de Rousseau contribuíram, sobremaneira, para modificar a interpretação e as representações da figura infantil. A infância, como etapa do desenvolvimento humano, será expandida- em parte, por efeito da recepção das ideias do filósofo genebrino (BOTO, 2017, p. 263).

O novo sentimento de infância percebido na formação do Emílio agrega uma nova compreensão da natureza, um novo ideal ético, no qual "Rousseau tornou-se o despertador da consciência moral", representando "uma reforma da mentalidade" (CASSIRER ${ }^{53}$ apud BOTO, 2017, p. 264). Desse modo, identifica-se em Rousseau, uma ideia de liberdade bem regrada "como ideal normativo da educação natural"54 (DALBOSCO apud BOTO, 2017, p. 264), abarcando as tentativas do genebrino de desenvolver uma via alternativa diante das dificuldades advindas da relação pedagógica entre adulto e criança.

O respeito e compreensão de cada etapa da vida da criança torna-se de fundamental importância: nada deve ser antecipado, com o risco de provocar o efeito

\footnotetext{
51 WEBER, M. A objetividade do conhecimento nas ciências sociais. In: CONH, G. (Org.). Weber. São Paulo: Ática, 1979. [São Paulo: Ática, 2006.]

52 BOTO, 2017, p. 203.

53 CASSIRER, E. A questão Jean-Jacques Rousseau. São Paulo: Editora Unesp, 1999, p. 91.

54 DALBOSCO, C. A. Paradoxos da educação natural no Émile de Rousseau: os cuidados do adulto.

Educação \& Sociedade, Campinas, v. 30, n. 106, p. 8, jan.-abr. 2009.
} 
contrário ao pretendido. A educação rousseauniana é a educação negativa, consistindo na preservação do coração do infante do vício, respeitando suas inclinações naturais. Parece-nos, como Carlota Boto (2017) ratifica, não ser gratuita a aproximação da infância ao homem em seu estado de natureza, sobretudo quando dirigimos um olhar mais atento ao amor de si, à vida em liberdade e à potência de perfectibilidade, tratados no Discurso sobre a origem e fundamentos da desigualdade entre os homens. O ponto principal diz respeito à noção que a "moralidade forma-se a partir do sentimento da piedade" (BOTO, 2017, p. 265). Dispondo desses sentimentos naturais a criança tem, também, a potência da moralidade em si.

O único indivíduo que faz o que quer é aquele que não tem necessidade, para fazê-lo, de pôr os braços de outro na ponta dos seus; do que se depreende que o maior de todos os bens não é a autoridade, mas a liberdade. O homem realmente livre só quer o que pode e faz o que lhe apraz. Eis minha máxima fundamental. Trata-se apenas de aplica-las à infância, e todas as regras da educação vão dela decorrer. A sociedade fez o homem mais fraco, não somente lhe tirando o direito que tinha sobre suas próprias forças, como também as tornando insuficientes. (ROUSSEAU ${ }^{55}$ apud BOTO, 2017, p. 266).

A importância do trecho acima cita diz respeito a uma compreensão da noção de liberdade que não se restringe, nas intencionalidades teóricas de Rousseau, apenas à criança ou ao homem natural, mas a ambos. Trata-se de uma reflexão sobre a "liberdade bem regrada". Adicionalmente, temos uma clara crítica do genebrino às artificialidades e necessidades criadas pela vida em sociedade, necessidades estas que não são naturais aos homens e, por essa razão, sendo estranhas à natureza humana, os enfraquecem:

Um aspecto fundamental do pensamento pedagógico rousseauniano é sua veemente crítica contra práticas de civilidade que- segundo o autor- destroem a espontaneidade no trato, criando ardilosas estruturas de linguagem, de comunicação e de interação humana. Circulava à época uma profusão de tratados de civilidade, os quais tinham por finalidade indicar normas do bom comportamento público das pessoas. As boas maneiras, para a aristocracia do século XVIII, eram fonte de distinção. (BOTO, 2017, p. 275).

${ }^{55}$ ROUSSEAU, J-J. Emílio ou da educação. São Paulo: Difel, 1979, p. 67. 
A autora enfatiza que no Discurso sobre as ciências e as artes, o genebrino recusa o "recurso à polidez como estratégia social" ${ }^{6}$, escondendo sob esse véu, todo tipo de vício e dissimulação.

Para Carlota Boto, tanto em Rousseau como em Kant, a liberdade supõe a possibilidade do desvio da regra pelo querer, a faculdade da escolha e "a consciência de ser capaz de fazer isso" ${ }^{57}$. Parece-nos que a ideia de perfectibilidade, ou a capacidade de se aperfeiçoar está, também, contida nessas noções de liberdade: a faculdade de escolha requer o desenvolvimento de uma moralidade que é cara ao genebrino. No homem natural, em sua transição ideal para a vida em sociedade feita por meio de um Contrato, é exigida a inclinação ética, embasada em uma virtude propriamente cívica, por vezes contando com a atuação do legislador, de se identificar com o compatriota, como parte do corpo. No caso do Emílio, temos a função do preceptor de atuar junto ao infante de modo a desenvolver essa moralidade, para que possa, na sociedade, "usufruir da autonomia"58: "A formação ética seria o fim último do desenvolvimento do menino Emílio". (BOTO, 2017, p. 273).

Thomaz Kawauche (2012), ao tratar da filosofia da existência de Rousseau nas análises de Pierre Burgelin"59, enfatiza o "sentimento de existência" como "condição mínima necessária para a busca da felicidade humana" 60 nas principais obras do genebrino. Para o filósofo, esse mencionado sentimento é reiterado na medida em que o homem vê sua existência expandida em direção a outros semelhantes: sua felicidade só pode ser vislumbrada na perspectiva de uma vida social compartilhada. As análises de Burgelin percebem, no Emílio, uma retomada dos princípios do amor de si e da piedade natural:

[...] quando a força de uma alma expansiva identifica-me com meu semelhante e sinto-me, por assim dizer, nele, é para não sofrer que não quero que ele sofra; interesso-me por ele por amor de mim e a razão do preceito está na própria natureza que me inspira o desejo de meu bem-estar em qualquer lugar em que me sinta existir. [...] $\mathrm{O}$ amor dos homens derivado do amor de si é o princípio da justiça humana. (BURGELIN apud KAWAUCHE, 2012, p. 36).

\footnotetext{
56 BOTO, 2017, 228.

57 BOTO, 2017, p. 267.

58 BOTO, 2017, p. 268.

59 BURGELIN, Pierre. La Philosophie de l'existence de J.-J. Rousseau. Paris: Presses Universitaires de France, 1952.

60 KAWAUCHE, 2012, p. 36.
} 
Essa "alma expansiva" representa a capacidade humana de identificação com seus pares, bem como referência do desdobramento do amor de si em um amor que abarca outros homens. Para Kawauche, "trata-se de uma imagem da virtude"61, em que o próprio Rousseau, no Emílio, entende-a como advinda dessa expansão do sentimento. Por envolver outros seres vincula-se, adicionalmente, à ideia de justiça.

Pode-se considerar que o ser social depende dos sentimentos naturais do amor de si e da piedade natural para bem agir em sociedade, "como árbitro"62 (DURKEIM apud BOTO, 2017, p. 267), e capaz de determinar o direito:

Durkheim interpreta que, de acordo com o traçado político da obrar rousseauniana, para existir justiça na vida civil, será necessária a existência de algo exterior aos indivíduos. Esse algo correspondesegundo ele- ao ser social. (BOTO, 2017, p. 267).

Segundo Carlota Boto, Rousseau confere um sentido muito particular em relação ao termo liberdade, podendo considerar duas liberdades: a do homem e a da criança, existente no primeiro estágio do homem no estado de natureza. Para o primeiro, a liberdade é escolha, para a criança, desejo: "pode-se dizer que a liberdade do homem adulto é escolha; escolha responsável"63. Sobre a liberdade do pupilo, a autora afirma que, para o genebrino, o tutor precisa respeitá-la, o que não significa que Emílio estaria autorizado a fazer o que quisesse. $O$ comando a ser conduzido pelo tutor é sutil, como uma arte, em que sua orientação não transparece ${ }^{64}$ :

A ideia de liberdade das crianças, na obra rousseauniana, deverá ser, em virtude disso, vista com algum cuidado. Emílio não é livre para proceder a escolhas significativas, mesmo que o tutor o faça crer que ele escolhe. Haveria um gradual aprendizado de se fazer escolhas. O tutor privará Emílio de todo supérfluo com o fito de que

\footnotetext{
61 KAWAUCHE, 2012, p. 36.

62 DURKHEIM, E. Montesquieu e Rousseau: pioneiros da Sociologia. São Paulo: Madras, 2008, p. 108.

63 BOTO, 2017, 268.

${ }^{64}$ Segue trecho que acentua esse aspecto: Mas a criança acreditará que escolhe. Isso não quer dizer que o tutor do Emílio seja desonesto com seu discípulo. A criança simplesmente não está preparada para tomar ciência de todas as facetas de sua educação. Será preciso, em alguma medida, iludi-la sobre a ideia de liberdade: "brincar" de liberdade. Enquanto o Emílio crê ser livre, ele terá disponibilidade de espírito para atender a orientação de seu tutor. Ele está aberto para aprender (BOTO, 2017, p. 270).
} 
ele bem possa compreender que as coisas não se curvarão naturalmente à sua vontade. (BOTO, 2017, p. 278)

De fato, há uma profunda reflexão sobre cidadania no Emílio, ao contrário do que diversos críticos apontam. A arte de viver em sociedade mostra-se como lição última para o pupilo que deverá, desde cedo, aprender a ponderar os seus desejos, em um contínuo exercício de uma "liberdade bem regrada". Crianças que fazem o que bem entendem e não são bem conduzidas, alimentam ideias contrárias às necessidades de uma vida comunitária, ao que questiona Rousseau: "[...] Se essas ideias de domínio e tirania as tornam desgraçadas desde a infância, que ocorrerá quando crescerem e suas relações com os outros homens começarem a estenderse e multiplicar-se?"65 (ROUSSEAU apud BOTO, 2017, p. 278). A extensão da existência humana em direção a outros pares, na vida em sociedade, reiterando a reflexão de Kawauche a partir dos apontamentos de Burgelin, depende do desenvolvimento da moralidade na criança ou jovem, na reta condução de seus sentimentos naturais.

A "ciência dos deveres do homem" (ROUSSEAU, 2004, p. 31) é comentado por Rousseau como o ensinamento do mais alto grau a ser garantido àquele que está em processo de formação. Antes desse conhecimento, cabe a ressalva que, para o filósofo, tudo deve ser apresentado ao infante segundo o ritmo da natureza, quando este estiver em condições de apreender os ensinamentos. Segundo a perspectiva apresentada por Rousseau no Emílio, a educação negativa proposta por ele prepara a criança para a condução à verdade e ao bem, quando estiver em condições de discernir e amar o bem. O exercício dos sentidos é o caminho para a razão, precedendo-a: "[...] o raciocínio infantil não ocorre a partir da mente, mas como fruto da ação dos sentidos" 66 . Essas noções apresentadas por Rousseau representam, sem sombra de dúvidas, sua crítica e contraponto aos modelos de educação vigentes da Europa do século XVIII, sobretudo os jesuítas, em seu verbalismo.

Boto observa que, para o genebrino, "[...] a formação ética sobreleva-se em relação ao preparo intelectual" [...] parar que ele possa cumprir, quando já formado, seus deveres para com a sociedade" 67 . A autora avança em um entendimento que

\footnotetext{
${ }^{65}$ ROUSSEAU, J-J. Emílio ou da educação. São Paulo: Difel, 1979, p. 72.

${ }^{66}$ BOTO, 2017, p. 282.

${ }^{67}$ BOTO, 2017, p. 269.
} 
indica um aspecto fundamental na compreensão de Emílio de Rousseau: "O educador do Emílio tem como meta a formação de um adulto consciente de sua relação com a natureza, consigo mesmo e com os outros". Desse modo, não é esperado que, quando adulto, Emílio seja apartado da sociedade, mas que saiba nela viver, cumprindo os seus "deveres de homem": A educação do Emílio prevê a possibilidade da interiorização individual dos sentidos de justiça. Emílio seria, ao final de seu processo pedagógico, homem moral e sujeito civil. (BOTO, 2017, p. 273).

Atrelando as noções de consciência moral à liberdade, nas reflexões indicadas por Kawauche (2012, p. 73-80) sobre alguns trechos da Profissão de fé presente no Emílio, observa-se que, para Rousseau, a concepção de liberdade está vinculada à condução de uma vida virtuosa e justa, promovida por meio da consciência. Consciência que, por sua vez, é sustentada por sentimentos, não por juízos. Seria um guia do homem orientado ou desenvolvido a partir dos sentimentos naturais, amor de si e piedade natural, capacitando o homem a discernir o bem do mal. A primeira parte da Profissão de fé analisada por Kawauche é ilustrativa a respeito do desenvolvimento da moralidade em Rousseau e às atribuições de sentido do genebrino às ideias de virtude e liberdade, atreladas ao discernimento e à capacidade de uma "reta escolha": "No sistema ordenado pela Providência, a liberdade humana coexiste com a necessidade das coisas. Por um lado o homem possui 'direito à virtude', pois é criado "livre para que ele fizesse não o mal, mas o bem por escolha"68.

Em um entendimento mais amplo dos escritos do genebrino, sobretudo no que diz respeito à vida em sociedade, podemos compreender essa ideia de escolha pela opção do homem pela vida em comunidade. Optar pelo "bem" é optar pelo bem comum. Inicialmente, a própria adesão ao Contrato social representaria uma escolha e um notável exercício da liberdade - uma escolha para si e ao mesmo tempo para o corpo político. O exercício da liberdade (nesse caso, liberdade civil), na sequência, diz respeito à ratificação diária dos princípios políticos pelo cidadão, a partir dos quais fundamenta sua existência política.

A segunda etapa da infância, considerada pelo genebrino, representa um estágio de função primordial para uma reta projeção do Emílio na sociedade, em que esteja destituído de artificialidades e necessidades vãs da vida em sociedade: nesse

68 KAWAUCHE, 2012, p. 74. 
momento, ele começa a discernir sobre a "relação entre suas forças e desejos"69. Desse modo, a contribuição da educação está na busca pelo equilíbrio entre as faculdades humanas e os desejos. A relação de confiança, admiração e amor, nessa relação preceptor-pupilo, relação que se estende pelo tempo de formação de vinte e cinco anos, não apresenta um caráter secundário. Esta confiança, por sua vez, é estabelecida na medida que o pupilo sente que as decisões do preceptor são justas, como se fossem acordadas entre ambos, mesmo sem estarem claras ${ }^{70}$. Tal relação, em seu caráter afetivo, lembra o elo estabelecido entre alguns romanos e seus mestres, ilustrada, a título de exemplo, pela relação entre o jovem Cícero com Cévola Áugure, a qual estendeu-se até a morte de seu formador, como comentado anteriormente no presente trabalho. Esse elo, por sua vez, era conquistado por mérito da experiência e da sabedoria do mestre. A respeito da relação preceptorpupilo, Maria de Fátima Simões Francisco (1999), ao tratar dos fundamentos do contrato pedagógico, ratifica a parte que cabe ao mestre, em que este coloca-se como superior em conhecimentos e experiências no processo de condução daquele que é inferior em relação a esses aspectos, conferindo autoridade ao mestre nos estágios de formação.

A criança inventada de Rousseau denuncia os vícios da sociedade adulta ${ }^{71}$ : partindo do reconhecimento da condição da criança, o genebrino parece construir pontes de acesso ou entendimento entre o respeito pelo estado de natureza humano e as possibilidades de formação do sujeito ético.

No livro I do Emílio Rousseau, ressalta a fragilidade do homem ao nascer: "Nascemos fracos, precisamos de força; nascemos carentes de tudo, precisamos de assistência; nascemos estúpidos, precisamos de juízo". (ROUSSEAU, 2004, p. 9). O genebrino aponta o homem natural como tudo para si mesmo, unidade numérica em contraponto ao homem civil, pensado como unidade fracionária ligada ao denominador, tendo seu valor em sua relação com o corpo da sociedade. Para desnaturá-lo, as boas instituições sociais seriam as mais aptas a realizar tamanho intento, capazes de lhe retirar a existência autônoma e conceder-lhe uma parcial. Trata-se da transferência do "eu" para a unidade comum.

Ao contrário das boas instituições sociais por ele consideradas necessárias, o

69 BOTO, 2017, p. 272.
70 BOTO, 2017, p. 255.
71 BOTO, 2017, p. 284. 
autor não deixa de criticar o estado decadente das que existem no seio da sociedade degradada, analisando-as nessa condição como castradoras da liberdade humana: "O homem civil nasce, vive e morre na escravidão; enquanto conservar a figura humana, estará acorrentado por nossas instituições" (ROUSSEAU, 2004, p. 16).

Nessa obra, o filósofo auxilia na percepção da realidade concreta, apresentando o quanto se está longe do padrão desejado, oferecendo indícios para se apreender o que é necessário fazer para alcança-lo. O método preceptorial é pensado como meio de salvar o homem no plano individual, uma vez que a sociedade se perdeu e não é possível uma educação pública autêntica. Esta obra, com elementos complementares ao Contrato social, não desconsidera, de modo algum, aspectos relativos ao homem civil, conforme esclarece Aragão:

No Contrato social o Legislador tem a missão de fazer um povo de homens ver a si mesmo tal como ele é; essa é, amiúde, também a missão do preceptor do Emílio para com as crianças. Pela educação o homem poderá agir na sociedade tornando-a uma organização que preze por sua liberdade, tentando resgatar no seio da sociedade, os subsídios que lhe auxiliarão nesta empreitada. (ARAGÃO, 2008, p. 48).

O genebrino ressalta que um pai, em seu dever de formador, quando gera um descendente e o sustenta realiza apenas uma parte de sua tarefa, já que "Ele deve homens à sua espécie, deve à sociedade homens sociáveis, deve cidadãos ao Estado" (ROUSSEAU, 2004, p. 27). Mais explicitamente, declara a existência de uma única ciência válida a ser ensinada às crianças: a dos deveres do homem.

Aragão ratifica a ideia que, para Rousseau, a criança é como o homem em seu estado originário, reunindo, conforme a natureza, as mesmas características. Ou seja, não é bom, mas também não é mau, já que não teve sua essência alterada pelos vícios de uma sociedade degradada, decadente. A educação da criança seria embasada no exercício de aprimoramento da natureza, perdida no processo civilizatório.

Pela educação, o homem encaminharia à sociedade melhores condições de torná-la uma organização que valorize a sua liberdade, resgatando no meio social os recursos necessários para validá-la. Ainda considerando essa assertiva, é importante ressaltar a coerência do modelo educacional defendido por Rousseau, que é contrário 
a todo e qualquer método que aliene o homem de si próprio ou que queira antecipar as etapas de formação. De modo contrário, intenta, valorizando o tempo da criança, pautado no presente, e protegendo-a contra caprichos, realizar na criança a sua essência, o que, consequentemente, poderia gerar condições de efetivação de um ser livre e senhor de si no futuro:

A principal crítica do autor dirige-se nesse momento à ação do mestre
homem - isto é, à educação do homem presente, ou, mais
precisamente, à "educação do mundo", tal como é chamada pelo
autor. Ao invés de pretender "desfigurar" e "revirar" tudo,
transformando o indivíduo num "monstro", o mestre homem deve
deixá-lo ser exatamente o que a natureza quer que ele seja.
(FRANCISCO, 2008, p. 58).

Ao declarar que pretende dar a Emílio uma maneira de viver conforme à natureza, Rousseau, ao contrário de negligenciar os deveres de um futuro cidadão, apresenta uma certa sinergia com relação a esse fim. Crescendo em liberdade e vigor, Emílio é cercado de disposições para a constituição futura de um homem civil, o qual não permitiria o cerceamento de seu ser livre: "O Emílio traça um atalho que parte da natureza para o pacto social de civilidade; um atalho entre liberdade natural e liberdade civil" (ARAGÃO, 2008, p. 49). Aquele que sendo ativo no corpo social, não se deixaria enclausurar por governos despóticos:

Ora, depois de ter-se considerado através de suas relações físicas com os outros seres, de suas relações morais com os outros homens, resta-Ihe considerar-se pelas relações civis com os outros cidadãos. Para isso, ele deve começar por estudar a natureza do governo em geral, as diversas formas de governos e finalmente o governo particular sob o qual nasceu, para saber se lhe convém viver nele; pois, por um direito que ninguém pode ab-rogar, cada homem, ao tornar-se maior e senhor de si, tornar-se também senhor da possibilidade de renunciar ao contrato pelo qual se liga à comunidade, deixando o país em que ela se estabeleceu. (ROUSSEAU, 2004, p. 673).

Também no Livro $\mathrm{V}$, o filósofo indica que o homem pode ter sua liberdade originária substituída pela liberdade civil, se se submete voluntariamente às leis para conquistar o direito de por elas ser protegido: "Cada um de nós põe em comum seus bens, sua pessoa, sua vida e toda a sua potência, sob a suprema direção da vontade geral, e recebemos em bloco cada membro como parte indivisível do todo". (ROUSSEAU, 2004, p. 680). Assim, insiste na ideia que os homens nascem livres e independentes, reunindo-se voluntariamente (que é o caso do Contrato) ou por força, 
"se a força que os reúne poderá um dia formar um direito permanente". (ROUSSEAU, 2004, p. 678). Além dessas colocações, indica que uma vez que a alienação do próprio ser é feita à comunidade toda e à vontade geral, cada homem ao obedecer a si mesmo e por isso é ainda mais livre no pacto social que em seu estado de natureza, já que se vê beneficiado pela contribuição de tantos outros concidadãos. Apesar disso, não é simples a tarefa do governante responsável. $O$ mesmo exerceria função primordial no processo de elevação e preservação do bem comum, seja por meio de festas cívicas, pela sua própria influência, seja, sobretudo, por suas instituições, como reforça no Contrato Social:

Aquele que ousa empreender a instituição de um povo deve sentir-se com capacidade para, por assim dizer, mudar a natureza humana, transformar cada indivíduo, que por si mesmo é um todo perfeito e solitário, em parte de um todo maior, do qual de certo modo esse indivíduo recebe sua vida e seu ser; alterar a constituição do homem para fortificá-la; substituir a existência física e independente, que todos nós recebemos da natureza, por uma existência parcial e moral. (ROUSSEAU, 1978, p. 57).

Nesse sentido, considerando a partir da obra do filósofo a instituição educacional como organização eficaz quando repensada a partir de valores que contemplem o bem comum, Aragão (2008) percebe a educação proposta por Rousseau como dissonante dos métodos educativos depravadores pelos quais 0 homem se entrega à história e se reduz a um escravo das instituições sociais, repetindo o percurso de degradação da espécie, sobretudo, o que se refere ao percurso educacional francês do século XVIII. As técnicas da época seriam voltadas para a submissão, como a do cueiro e do ajustamento do crânio com as mãos. Estas práticas eram pensadas pelo genebrino como desnaturações impróprias à natureza humana. Decorrendo do pacto social, consentido e apoiado pelos cidadãos, todas as etapas de formação e socialização do homem, desde a base familiar e agrupamento em comunidades até a compleição do Estado, configurar-se-iam em momentos de desencadeamento de um processo formativo promissor:

É na sociedade que ele funda a sua nova natureza, uma natureza renaturada. O desafio proposto a partir da crítica de Rousseau não é o de tirar o homem da sociedade e sim pensar nessa sociedade como a nova casa do homem. (ARAGÃO, 2008, p. 93). 
Em artigo intitulado Rousseau e a questão das educações pública e doméstica, Maria de Fátima Simões Francisco problematiza a interpretação recorrente do autor, segundo a qual, Rousseau teria deixado de lado a educação pública e a formação do cidadão optando, exclusivamente, pela educação doméstica e a formação do homem. Embasando-se em passagem do Emílio em que é exposta a contradição homem-cidadão e o dilema subjacente a esse paradoxo, Francisco (2010) aponta para a hipótese de que o genebrino vislumbra uma conciliação ou "concerto" entre o homem e o cidadão.

Considerando os trechos que sustentam o mencionado paradoxo, quais sejam "[...] optar entre fazer um homem ou um cidadão, pois não se pode fazer os dois ao mesmo tempo" e "[...] se porventura o duplo fim que nos propomos pudesse reunir-se em um só, suprimindo as contradições do homem, suprimiríamos um grande obstáculo à sua felicidade"72 (ROUSSEAU apud FRANCISCO, 2010, p. 62), temos a observação da autora que reflete: nada impediria a formação em sucessão, constituindo primeiro o homem natural e, em um segundo momento, o cidadão. Tal possibilidade é seguida pelo questionamento a respeito de como formar seres tão antagônicos, já que um combate o cidadão e o outro exige a desnaturação do homem.

Dado que a "dimensão contraditória do texto é propriamente insolúvel", (FRANCISCO, 2010, p. 63), a autora avança em seu raciocínio na iniciativa de compreender a intenção do filósofo ao produzir esse efeito da contradição: o que pretende o autor ao provocar esse efeito?

Pode ser útil recordar nesse momento que Rousseau deixa explícito em seus textos que pretende apelar não apenas à razão do leitor, mas ao conjunto de seu ser, aí incluídos os sentidos, as paixões, a imaginação, e o "sentimento interior", todos os quais, porque essenciais, são invocados para deliberar sobre a adesão às verdades propostas. (FRANCISCO, 2010, p. 64).

Quais seriam, então, as verdades propostas que o genebrino procura mostrar em sua tentativa de mobilizar e conduzir o leitor? Ao fazer uso desse recurso estilístico, recorrendo à piedade natural e empatia daquele que lê, o autor pretende

72 ROUSSEAU, J-J. Emílio ou Da educação. São Paulo: Martins Fontes, 1995, p. 13. 
"fazer o leitor viver os sentimentos e o desconforto deste", do ser aflito pela contradição de caráter ontológico, vivida pelo homem. (FRANCISCO, 2010, p. 64).

Essa contradição, que interfere diretamente sobre a felicidade do homem, deve ser eliminada, de modo a engendrar o bem-estar a que Rousseau se refere ao colocar como meta que o homem esteja em "acordo consigo mesmo". O paradoxo entre homem e cidadão destaca-se como a

[...] reproposição, no plano da existência individual e no da pedagogia, da contradição e dualidade mais gerais, em torno das quais gira todo o pensamento de Rousseau, vale dizer, entre natureza e sociedade. [...] A própria educação doméstica, que faz o homem, é dita "educação da natureza." Do lado do cidadão e da sociedade [...] encontramos: "homem civil", "ordem civil" e "instituição pública". (FRANCISCO, 2010, p. 66-67).

Ao passo que no Contrato é apresentada uma solução no plano políticojurídico à contradição entre as vontades particulares e a vontade geral, no Emílio trata-se da existente entre homem e cidadão, a partir de sua trajetória e formação individuais, ratifica Francisco. A formação do homem natural compõe a principal crítica do genebrino à "educação do mundo", que desfigura o indivíduo e o transforma num "monstro". Por essa razão, justificar-se-ia o encaminhamento pedagógico proposto pelo mestre homem ao deixar o seu pupilo tornar-se o que a natureza pretender que ele seja.

A impossibilidade colocada por Rousseau, ao afirmar que não se pode fazer homem e cidadão ao mesmo tempo, por exigirem o combate às instituições sociais ou à natureza, nas páginas iniciais do Emílio, é seguida, nos parágrafos subsequentes, a uma exaltação do cidadão, quase destacado como uma coroação ou meta a se conquistar na formação do indivíduo. (FRANCISCO, 2010, p. 69). Não se trata, no entanto, da formação de qualquer cidadão inserido em uma sociedade qualquer, mas de um cidadão exemplar formado em uma sociedade exemplar. Isso porque entre os modernos, com exceção de Genebra, Rousseau não encontrava sociedades cujas instituições sociais não estivessem corrompidas. É nesse sentido que Rousseau busca suas referências com entusiasmo na antiguidade.

Se examinarmos com atenção a descrição exaltadora dos cidadãos antigos, percebemos que traz implícito um importante pressuposto: a mais absoluta eliminação do homem natural. Para esses cidadãos 
somente existe o interesse da cidade, o exemplo da mãe espartana sendo o mais eloqüente. Diante da perda de seus cinco filhos, ela somente se lembra de render glória aos deuses pela vitória da cidade, em nenhum momento demonstrando qualquer hesitação em razão de uma eventual dor oriunda de sua desgraça pessoal (FRANCISCO, 2010, p. 69).

Ao enfatizar o lugar fundamental das instituições no percurso formativo humano, Rousseau declara sua valorização ao processo de desnaturação, quando voltado ao nobre objetivo da unidade comum, formando o homem "sensível no todo". No Emílio, o genebrino deixa de adotar essa via de formação, "que seria a preferível em princípio", para optar por formar o homem natural, uma vez que as instituições públicas contemporâneas a ele não constituem mais "pátria" ou pilares de uma vida política voltada ao bem coletivo. Francisco, sem deslocar a clara intenção de Rousseau no Emílio de formar o homem natural, afirma que, adicionalmente, o autor procura as vias para se chegar ao cidadão, o que constituiria não apenas uma obra de educação doméstica, mas também de educação pública. Para a autora, o plano da preocupação de Rousseau quanto à República que o futuro cidadão habitará, é primordial na escritura do Emílio.

Será que a própria natureza já traz dentro de si a resolução da contradição homem-sociedade, ou, ao menos, as pré-condições para isso? Se assim for, então podemos ter a esperança de construir uma história diferente daquela apresentada no Discurso, uma em que o homem possa se tornar ser social sem alienar e deixar para trás as vantagens do estado de natureza - igualdade, liberdade, individualidade. (FRANCISCO, 2010, p. 73-74)

Considerando as disposições naturais do homem, quais sejam, amor de si e piedade natural, poderíamos, então, admitir que a República é, na verdade, uma contínua formação e um contínuo exercício do bem público, do bem de cada membro do corpo social, consequentemente. O bem público pode ser interpretado, a partir dessas pré-disposições naturais, como alicerce firmado no amor de si e na piedade natural. Aceitar o contrato jurídico rousseauniano é uma escolha racional e, primordialmente, de alma $^{73}$, pautada na preservação de si e no bem querer do próximo, concidadão e parte da pátria.

\footnotetext{
${ }^{73} \mathrm{Em}$ Considerações fala-se em alma nacional, constituída pelo amor à pátria, por meio da educação e das festividades e eventos nacionais de caráter formativo.
} 
A necessidade do "acordo consigo mesmo", destacado no Emílio, aparece, segundo Francisco, como finalidade da história de formação humana. Para alcançar a felicidade, o indivíduo humano precisaria alcançar esse estado de conciliação em que seja "bom para si" e "bom para os outros" 74 , viabilizar o "concerto" da contradição entre homem e cidadão: "De fato, ela é própria de todo indivíduo humano e intrínseca à condição de homem. Tanto é assim que o próprio Emílio, o indivíduo formado segundo as prescrições da natureza, também a enfrenta" (FRANCISCO, 2010, p.75-76).

Dadas a inexistência na sociedade contemporânea a Rousseau de instituição pública e pátria, decide-se formar o homem natural. Tal formação é seguida, no entanto, concluída essa formação, pelo ser social, que se faz membro do corpo político junto aos seus pares. Ao contrário das interpretações recorrentes, como reforça Francisco no início do mencionado artigo, no Emílio podemos vislumbrar a exaltação do cidadão pelo autor, parte do todo.

74 FRANCISCO, 2010, p. 74. 
CONSIDERAÇÕES SOBRE O GOVERNO DA POLÔNIA E SUA PROJETADA REFORMA: UMA COMPOSIÇÃO REPRESENTATIVA DA LEITURA ROUSSEAUNIANA DE REPÚBLICA E EDUCAÇÃO

Nessa obra supracitada, Rousseau parte do quadro governamental do país, apresentado pelo Conde Wielhorski, para a partir deste conjunto de documentos informativos, elaborar um projeto para a reforma do país. Vemos, não somente uma proposta com um fim em si mesma, específica à Polônia e sem nenhuma abrangência além das fronteiras desta nação, mas, também, uma composição bastante representativa do pensamento e da filosofia do autor. Nela podemos encontrar elementos que parecem clarificar a temática em questão neste tópico, abrangendo elementos concernentes à formação do cidadão pensado por Rousseau e a constituição de uma alma patriótica: "Rousseau defende um projeto de educação coletivista e patriótico". (BOTO, 2017, p. 235). Por esse motivo, é de fundamental importância destrinchar algumas partes de Considerações, visando melhor compreender a natureza e alcance desta obra. Antes, a ressalva de Salinas Fortes (1988) parece-nos adequada para adentrarmos nas linhas que se seguirão. Dos povos contemporâneos ao genebrino, apenas a ilha de Córsega poderia ser organizada de acordo com o imperativo da vontade geral, para a qual Rousseau redigiu um projeto de Constituição. Considerações, compreendida por Salinas como um complemento significativo das teses abstratas do Contrato, o genebrino julga a Polônia como estado não inteiramente legislável e, por essa razão, faz-se necessária uma permanente adaptação às circunstâncias e aos objetivos teóricos dos leitores que se proporem a refletir e escrever sobre essa obra. Não devemos, portanto, considera-la como praticável, sem observar suas especificidades. Aqui, o intuito é destacar o que este escrito pode nos ensinar a respeito de alguns dos mais relevantes princípios políticos e educacionais do autor.

Não obstante, o presente tópico possibilita a observação dos temas presentes nos anteriores, condensados e ilustrados nesse arranjo reflexivo. Nesse livro vislumbra-se, mais uma vez, o espírito crítico de Rousseau perante o cenário europeu, que influía descontroladamente sobre o mundo, no contexto do antigo regime e da ascensão da burguesia. A apresentação da paixão patriótica destacase, com inclinações mais cosmopolitas que patrióticas, ao refletirmos sobre o 
período que procede o século XX:

Chama a atenção que no filósofo esclarecido, idealizador do Estado popular, o patriotismo, tão acentuado neste projeto para a Polônia, seja dado como vida do indivíduo. Após o século XX, quando se vê com certa distância o doloroso momento do nacionalismo europeu e quando o cosmopolitismo parece mais consoante às necessidades de paz e de convivência desta época em que as tecnologias condicionam à mundialização, o entusiasmo patriótico rousseauniano causa espanto. (ALBORNOZ, 2006, p. 76).

Além desses elementos, Rousseau posiciona-se contrariamente à tendência das novas circunstâncias modernas, que já começavam a enaltecer a figura do indivíduo em prejuízo do sentimento patriótico e voltado à sociabilidade. Assim, atacava as "máximas corrompidas" advindas de uma "filosofia egoísta". Também na educação, vê-se a contínua preocupação do genebrino que, não raramente, detémse em aconselhar os dirigentes poloneses a guiarem-se pelo que pode ser entendido como humanismo nacionalista, em contraponto aos ventos contrários que cercavam a nascente revolução industrial.

A Polônia é apresentada como um país vulnerável a começar por sua história, marcada por desunião e movimentos conflituosos, por tentativas de desenvolver metas comuns desfeitas reciprocamente: "[...] sua esperança [de Rousseau] é que a inspiração nos valores populares da Polônia deem a esse país as sonhadas harmonia e força para afirmar sua independência diante dos seus tradicionais invasores" (ALBORNOZ, 2006, p. 80). Apesar disso, um aspecto proveitoso é destacado, um entusiasmo juvenil que se configura como esperança entre infortúnios e desgoverno, que ousa demandar uma orientação governamental e legislativa. É comparada com Roma sitiada pacificamente dividindo a terra em território já tomado pelo inimigo. Não obstante, posiciona-se assim porque é motivada por uma "força" primordial, que pode ser percebida como a força da natureza: "Está presa a grilhões e discute os meios de permanecer livre; sente em si mesma o tipo de força que o poder da tirania não pode superar". (ROUSSEAU, 2003a, p. 224).

Com espírito pragmático, Rousseau alerta que as leis, ainda que sejam excelentes em sua concepção, estão expostas às paixões humanas, e por isso prever as transgressões dos homens estaria fora do alcance do estadista mais experiente. Por isso, o que haveria de mais plausível seria inculcar a legislação no coração do 
homem, de forma que o ato de a transgredir seja contrário ao próprio sentimento desenvolvido. Mas, questiona o autor, como fazer os homens amarem suas leis, sua pátria? Como educa-lo para tal? Antes de elaborarmos essa questão em sua especificidade, contextualizaremos outros elementos da obra que ajudam a circunscrever a questão.

Discernindo sobre a história da Antiguidade e seus grandes homens, 0 genebrino reconhece um ambiente e personagens diferenciados dos de sua época: "Que têm os franceses, ingleses ou russos em comum com os romanos e os gregos? Quase nada, excetuada sua aparência externa" (ROUSSEAU, 2003a, p. 226). Os obstáculos postos para esse distanciamento seriam a "mesquinha filosofia", 0 egoísmo reinante e instituições fracassadas. Um dos principais motivos para a sustentação dessa situação estaria no fato que o autor conseguia notificar "fazedores de leis", mas não legisladores. Para isso explicitar, recupera as figuras de Moisés, Licurgo e Numa como exemplos de legisladores. Sobre Licurgo, apresenta um homem que, partindo de uma nação desgastada pela servidão e maus costumes, impõe-lhe um domínio, uma disciplina jamais sentida. Assim, pode uni-lo por sua identidade comum, mantendo-o em contínua atenção à pátria, fosse nos jogos, leis, ambientes domésticos e festivais. Dessa disciplina e exposição, decorreu o conhecido vínculo patriótico espartano, que sustentava e enobrecia a cidade-estado. Para o autor, este amor à pátria foi o principal responsável pela influência e poderio espartanos. Esse espírito, essa alma nacional teria orientado os antigos legisladores, todos teriam buscado meios de união entre os cidadãos e a pátria, como em cerimoniais religiosos, jogos, exercícios físicos comunitários (fortificavam a autoconfiança) e espetáculos (relembrando fatos da história comum).

A legislação polonesa é, pelo genebrino, assemelhada a outras da Europa, constituída "pedaço após pedaço". A fim de reprimir um abuso, outra lei é feita, e quando surgem outros abusos, outras são elaboradas. Multiplicando-as, esse procedimento engendraria o enfraquecimento estrutural da Constituição. Sua Dieta, ainda que soberana, não conseguiu fortalecer-se e se fazer obedecer, situação que o autor procurou investigar. Essa problemática é associada aos reinados que tradicionalmente começavam do mesmo ponto ao iniciarem, obrigados pelas cláusulas convencionais polonesas, impedindo um progresso considerável. Assim, também Ministros e demais autoridades tinham seu trabalho já inicialmente 
prejudicado. É igualmente percebida a autoridade executiva, que se fragmentava por vários ocupantes, os quais, por essa situação, desenvolviam um diálogo pouco coeso. Analisando as limitações do poder executivo, Rousseau defende que armá-lo com um órgão consistente como o Senado, manteria os ocupantes atentos às suas obrigações, ainda que se veja como tendência perniciosa abafar a autoridade legislativa. Em contraponto, o genebrino exemplifica o Senado de Roma, afirmando que este não subjugava a autoridade legislativa, pois dispunha de leis acompanhadas por censores, de povo revitalizado por seus tribunos e senadores que não elegiam cônsules:

Para que a administração seja forte, eficaz e caminhe bem na direção do seu objetivo, toda a autoridade executiva deve estar nas mesmas mãos; mas não basta que essas mãos mudem: é preciso que só possam agir sob os olhos do legislador, guiadas por ele. Eis aí o verdadeiro segredo para que não usurpem a sua autoridade. (ROUSSEAU, 2003a, p. 249).

Preocupando-se com a constância ética no campo político da Dieta, o autor indica frequência de troca dos partícipes, de modo a afastá-los de qualquer ameaça à liberdade: "Em um Estado livre devemos prever tudo o que pode prejudicar a liberdade". (ROUSSEAU, 2003a, p. 253). Sobre estes aspectos, destaca a relevância das assembleias locais, consideradas por ele o verdadeiro símbolo deste bem e meio de estender a autoridade: "[...] não há bem maior do que um bom cidadão poder expressar-se quando tem coisas úteis a dizer". (ROUSSEAU, 2003a, p. 255). Os deputados estariam sob vigilância por seus eleitores no que diz respeito às instruções recebidas e respectivos deveres legislativos, sendo que o relato de suas tarefas formaria a base para julgar se seguiram satisfatoriamente o mandato, e se seriam dignos de honrar um novo mandato, uma vez que suas funções estariam a serviço da vontade de seus compatriotas (expressa nas leis), não de suas inclinações pessoais.

A temática da autoridade política em Considerações se ramifica e fortalece como assunto que detém a atenção do genebrino. Ao enfatizar os encargos do monarca, atenta para a necessidade de retirar seu poder de escolher os membros do Senado. Mais do que uma tentativa de debilitar a capacidade de influência do monarca, Rousseau tem os olhos no povo, ao perceber tal retirada como enfraquecimento do espírito cortesão em prol do espírito patriótico. Não sem motivo 
a mudança é proposta, já que os senadores exerceriam seu poder atuando como intermediários entre os deputados e o rei, grupo este que seria contrabalanceado por membros temporários, em lugar da exclusividade dos vitalícios. O poder ao rei delegado de nomear senadores é mal visto por Rousseau, que isso considera um contraponto a uma representação mais genuína da população, intentando, assim, que essa figura seja sempre amiga da liberdade. O monarca é visto também como representante supremo vitalício necessário para um Estado com as extensões da Polônia. Tendo essa importância simbólica, o autor também não vê satisfatoriamente a retirada de todas as suas funções, ao contrário disso, as percebe como elementos de extrema relevância para a preservação do bem público:

Terá pouca força imediata e direta para agir por si mesmo, mas não Ihe faltará bastante autoridade, assim como a capacidade de inspecionar a vida pública para manter todos os que dela participam bem ocupados em cumprir o seu dever, orientando assim o governo para o seu verdadeiro objetivo. (ROUSSEAU, 2003a, p. 265).

Sobre a influência do rei, o genebrino não deixa de ser categórico: para ele, é crucial enfraquecer tanto quanto possível seu alcance no trato com as finanças da nação. Assim, todos os que ocupassem os cargos relativos a essas demandas não deveriam ser nomeados pelo monarca, mas sim partir de uma lista de candidatos elaborada pela Dieta.

Também pela preservação da liberdade, a coroa hereditária é percebida por Rousseau como um elemento negativo ao bem comum: "Para resumir o que penso a este respeito, creio que para a Polônia uma monarquia eletiva com o poder mais absoluto seria melhor do que uma coroa hereditária quase desprovida de poder". (ROUSSEAU, 2003a, p. 264). Para viabilizar esse raciocínio, é considerada uma lei na qual a coroa não seria passível de transferência ao filho, pelo menos no que diz respeito a uma sucessão imediata. Não podendo usurpar o poder, o rei estaria mais inclinado a dirigir seus cuidados à prosperidade da pátria. A hereditariedade permaneceria limitada à nobreza, sem extensão adicional.

A atribuição de parte dos encargos políticos é proposta do seguinte modo: "[...] os Paladinos e Governadores, vitaliciamente, pelas respectivas assembleias locais; os Governadores de segunda ordem por tempo determinado e pela Dieta". (ROUSSEAU, 2003a, p. 261-262). Não obstante, propõe a instituição de um equilíbrio político a permear os poderes legislativo e executivo. Estes respectivos poderes 
estariam "na razão do seu número e inversa à duração da sua existência". (ROUSSEAU, 2003a, p. 265). Dessa forma, o Senado disporia de menor número de membros e participação reduzida nas questões legislativas, mas teria maior influência na executiva. Em convergência a esta proposta tentativa de equilíbrio, está a constante preocupação do genebrino com a temática do merecimento entre as autoridades do Estado. Vê-se, por exemplo, que um deputado só poderia exercer novo mandato com aprovação, e uma vez conquistados três mandatos cumpridos satisfatoriamente, seria alcançado um novo degrau no serviço público, a insígnia de "Guardião das Leis". Esta seria concedida pelo Rei, depois de assentimento pela Dieta. Para se tornar um Paladino e mesmo um Grande Governador, seria preciso estar entre os Guardiões.

Uma proposta peculiar para a sua época é levantada como possibilidade por Rousseau, ao enaltecer uma sugestão de ingresso à nobreza pelos burgueses e aquisição da liberdade e cidadania pelos servos: "[...] listas seriam remetidas ao Senado e ao Rei para que fossem consideradas oportunamente, de modo a orientar a sua preferência e as suas escolhas”. (ROUSSEAU, 2003a, p. 299). Essas listas orientariam os gestores da educação para a concessão de bolsas, além de enobrecer os camponeses que se destacassem pelo cumprimento de seus deveres em todas as esferas que suas vidas Ihes exigissem, poderiam tornar-se ainda mais honrosos, e partícipes cidadãos. O que tamanho benefício proporcionaria gradualmente? O filósofo explica:

Quando um certo número de famílias tivesse sido liberado de forma sucessiva em um determinado cantão, seria possível liberar aldeias inteiras, formando aos poucos comunas, que receberiam uma propriedade, terras comuns como na Suíça, estabelecendo aí autoridades comunitárias e, assim gradualmente, seria possível, sem qualquer revolução, terminar com uma mudança em larga escala, dando ao povo o direito, que teria naturalmente, de participar da administração do seu país, credenciando Deputados junto às assembleias locais. (ROUSSEAU, 2003a, p. 300).

Com essa transformação, reforça o autor, estes que eram inicialmente camponeses, seriam equipados e preparados para compor uma exímia milícia para a defesa da nação.

Os títulos de nobreza teriam uma extensão diferenciada, de forma a poderem ser concedidos coletivamente a cidades, e não a particulares, que apresentassem atividades comerciais, industriais e artísticas dignas de nota, as quais adviriam, por 
consequência, de uma administração municipal responsável pelo reconhecido progresso. Servindo bem à pátria nessas condições, os homens teriam, pela virtude, a chance de almejar e alcançar os caminhos mais desejáveis que nascem em um coração de um compatriota de conduta merecedora. 
Como formar, então, honrosos cidadãos, em sinergia com o bem comum, com a República? A essa questão, o genebrino parece apresentar importantes indicativos já no primeiro parágrafo do Capítulo IV, A educação: "Cabe à educação dar aos espíritos uma formação nacional, orientando seus gostos e opiniões de modo que sejam patriotas por inclinação, por paixão e por necessidade". (ROUSSEAU, 2003a, p. 237). Sobre a relevância da educação, o autor a coloca entre as instituições fundamentais para o destino satisfatório das nações. O vínculo estabelecido com sua pátria seria tamanho, que o indivíduo não conseguiria visualizar uma existência feliz isolado de sua nação e de seus concidadãos: a obra "defende uma escolarização voltada para ancorar a existência nacional mediante ritos e saberes programáticos dirigidos à formação de uma coletividade disciplinada e virtuosa" (BOTO, 2017, p. 239).

Analisando o papel da educação na proposta do autor, Albornoz, em seu artigo "Educação e trabalho nas Considerações sobre o governo da Polônia (1771) de Jean-Jacques Rousseau", destaca:

A organização pública da educação é ali apresentada como de importância central, sobretudo na formação do que chama de "alma nacional". Rousseau considera a educação o meio de construção da nação e a grande tarefa nacionalista. É pela educação que seria possível criar a identidade e a força do país. (ALBORNOZ, 2006, p. 76).

Conectando educação nacional à noção de liberdade, o genebrino critica a tendência europeia à licenciosidade, ressaltando que os jovens já saem da escola preparados para a servidão, em um processo de aceitação das estruturas governamentais de seus respectivos países. Criticamente, elabora suas prioridades de formação mais condizentes com o espírito patriótico: "A escola patriótica pensada para a Polônia era a estratégia da reforma política" 75 . Albornoz ratifica a ideia que a boa educação seria examinada pelo grau de inserção da população na cultura geral, vista como cultura popular, e seu respectivo sentimento de pertencimento:

O primeiro objetivo da educação aparece nesse texto de Rousseau como sendo a identificação do homem particular com o seu povo, a identificação do indivíduo com o cidadão e a impregnação do

75 BOTO, 2017, p. 238. 
indivíduo com a identidade nacional. É esse processo de identificação com a pátria que constituirá o lastro da disciplina pessoal, que por sua vez garantirá a verdadeira liberdade. (ALBORNOZ, 2006, p. 76).

Como ressalta Carlota Boto, há pontos de convergência entre Considerações e o texto sobre "Economia Política", verbete da Enciclopédia francesa, ambos projetos de educação pública "com a baliza simbólica do Estado-nação como artífice e diretor desse mesmo ensino"76. No que diz respeito a este vínculo patriótico, por exemplo, "Rousseau assinalava o papel cívico e civilizador da educação pública"77, onde as crianças, desde cedo, desenvolveriam suas identidades em interação com os outros membros do corpo político, percebendo sua existência como parte do todo: "A escola, nessa medida, cumpriria a tarefa de construção ritual de uma pedagogia cívica" ${ }^{\prime \prime}$, cuja meta principal seria promover o fortalecimento da identidade coletiva e o sentimento de pertença. O Discurso sobre economia política (1996), no qual a educação é apresentada como dever público e a mais essencial tarefa do Estado, foi publicado em 1755, contendo associações e distinções entre os governos doméstico e civil. Na economia descrita por Rousseau, onde os diferentes ambientes da cidade estariam integrados, os cidadãos, enquanto corpo, -que é um corpo moral por possuir uma vontade, a de todos-, seriam os responsáveis pelo movimento, vida e trabalho da máquina política. A legitimidade deste corpo moral estaria no cumprimento da vontade geral e orientação segundo a mesma: "O legislador conforma-se às leis da vontade geral e a economia política corresponde à administração conforme tais leis"79. Nota-se que o encaminhamento das vontades particulares para a vontade geral caracteriza, nesse contexto, a ideia de virtude para Rousseau, como a "adequação do particular ao coletivo"80.

O verbete sobre "Economia política" toma por pilar norteador a tentativa de concepção de um modelo de administração do bem público qualificada como pertinente à definição de vontade geral. Para tanto, a pedagogia tem lugar privilegiado. Trata-se de estruturar o papel cívico e civilizador da educação do Estado. Será preciso, por meio da escolarização, formar a individualidade das pessoas em

\footnotetext{
${ }^{76}$ BOTO, 2017, p. 238-239.

77 BOTO, 2017, p. 234.

78 BOTO, 2017, p. 234

79 BOTO, 2017, p. 233.

80 BOTO, 2017, p. 233.
} 
incessante interação com a coletividade. Só assim a educação nacional contribuirá para a existência coletiva. (BOTO, 2017, 239).

Para o genebrino, a educação pública constitui uma das máximas fundamentais para um governo legítimo. A educação das crianças no seio da igualdade e das leis do Estado, aprendendo desde cedo a compreender e respeitar a vontade geral, entendendo os bens que dela decorrem ${ }^{81}$, fomentaria o amor entre os concidadãos e à pátria, e o desejo de perpetuar o legado deixado pelos mais velhos.

A respeito desse legado, temos o caráter formativo dessa educação proposta por Rousseau que não se restringe à educação pública entendida apenas como representada por meio das instituições escolares, mas parte da vida em comunidade no seio da pátria. Jovens e crianças são incentivados a aprenderem, nessa vida política em constante atividade, "apenas a olhar sua individualidade por meio de suas relações com o corpo político", percebendo "sua própria existência como uma parte da que, poderão vir finalmente a se identificar de alguma forma com esse todo maior"82. A partir dos exemplos vislumbrados cotidianamente nas vidas dos concidadãos, estariam dispostos a representarem a pátria, seja na vida pública, seja na guerra, aprendendo a "substituir o falatório vão e estéril dos sofistas por ações de homens e de cidadãos, e um dia se tornarão os defensores e os pais da pátria, da qual foram por muito tempo os filhos" ${ }^{83}$. Mais adiante, é enfatizada a noção do âmbito formativo na República:

Uns e outros formarão dessa maneira virtuosos sucessores e transmitirão, de época a época, às gerações futuras, a experiência e os talentos dos chefes, a coragem e a virtude dos cidadãos e a emulação comum a todos de viver e morrer pela pátria (ROUSSEAU, 1996, p. 41).

Com exemplos retirados dos antigos, o genebrino convida o leitor a refletir sobre o vínculo construído entre os cidadãos, unindo-os na tomada de decisões e no cultivo da virtude nas pequenezas da vida republicana. Comenta que diante de uma situação que envolvia a punição de um cidadão, toda a república em Esparta abatiase. Ressalta os romanos como o povo merecedor de reconhecimento "pela consideração do governo pelos particulares e por sua atenção escrupulosa em

\footnotetext{
81 "Então que a pátria se mostre a mãe comum de todos os cidadãos, que as vantagens que usufruem em seu país a tornem amada" (ROUSSEAU, 1996, p. 38).

82 ROUSSEAU, 1996, p. 39.

${ }^{83}$ ROUSSEAU, 1996, p. 41.
} 
respeitar os direitos invioláveis de todos os membros do Estado"84. Era necessária a reunião de todo o povo para uma decisão definitiva. Mais adiante, acentua:

Em Roma e nas suas tropas, tudo deixava transparecer esse amor dos cidadãos uns pelos outros, a esse respeito pelo nome romano que elevava a coragem e animava a virtude de quem quer que tivesse a honra de carrega-lo. Nas comemorações dos triunfos o que mais chamava à atenção era o chapéu de um cidadão libertado da escravidão ou a coroa cívica daquele que salvou a vida de um outro [...] (ROUSSEAU, 1996, p. 37).

Em seu programa, o genebrino atenta para a necessidade do polonês sentirse genuinamente polonês pelo conhecimento apurado de sua pátria. Almeja que este cidadão deixe a escola tendo em sua trajetória educacional leituras sobre seu país tão logo aprenda a ler, aos dez anos pretende um estudante familiarizado com as produções nacionais; dois anos depois, o conhecimento da geografia e das vias de tráfego; aos quinze, o entendimento da história da Polônia. Aos dezesseis, o saber das leis, como forma de ratificar a consciência de cidadão.

Para Rousseau, a educação dirigida por padres e estrangeiros é indesejável. A legislação deveria demarcar o conteúdo e a forma dos objetos de estudo. O professor, por sua vez, deveria ser polonês e distinguir-se pelo caráter e por suas realizações. Desse modo, o autor levantava polêmica para a época, cujo período histórico trazia forte tendência de admitir professores estrangeiros, sobretudo, franceses.

A divisão educacional frequente da época, entre nobres ricos e nobres sem recursos, é repudiada pelo genebrino, pois isso contrariaria a legislação, pela qual todos são iguais. Sabendo das dificuldades de instituir uma educação plenamente pública e gratuita na época, apresenta a indicação de que ao menos tenha um preço que os pobres possam ter acesso, ou a criação de vagas gratuitas nos colégios, sob zelo estatal.

A respeito dos conteúdos a serem ministrados e das habilidades a serem desenvolvidas, além do ensino do repúdio à dominação, em História, por exemplo, indica a instrução de valores políticos, e nas Artes o desenvolvimento de um olhar crítico e reflexivo. $\mathrm{O}$ autor discorre, também, sobre a importância dos exercícios físicos nos

${ }^{84}$ ROUSSEAU, 1996, p. 37. 
ginásios, considerados a parte mais relevante da educação por seu efeito moral, e pela formação de corpos sadios. Sobre a primeira justificativa, aponta a educação negativa como meio de impedir o desenvolvimento dos vícios:

Rousseau sugere também que os colégios criassem ginásios esportivos para todos os alunos fazes exercícios físicos; não apenas para formar jovens sadios, mas porque compreende que exercícios físicos possuem valor moral. (BOTO, 2017, p. 237).

Nesse sentido, propõe jogos em conjunto, "de forma que haja sempre um objetivo comum a que todos aspiram". (ROUSSEAU, 2003a, p. 239). Sobre isso, faz uma observação indicando que os pais que optaram pela educação doméstica teriam que, ao menos, enviar seus filhos para participarem de exercícios corporais coletivos: "[...] é preciso habituá-los desde cedo às regras, à fraternidade, à competição, a viverem expostos aos seus concidadãos e a almejarem a aprovação pública" (ROUSSEAU, 2003a, p. 239). A competição e a mencionada aprovação, não são aspectos que intencionam uma hierarquia dos mais capacitados, mas elementos que colaboram na busca, desde a infância, da excelência do cidadão. Tal excelência, objetivando cada vez mais o melhor daquele que a procura, impulsionaria o estudante a oferecer ainda mais à sua pátria sem se opor à sua própria natureza de crianças que, pela própria constituição, necessitaria mover-se, mantendo os pressupostos do distanciamento de atividades penosas e inclusão de exercícios corporais agradáveis ao organismo, inclusive na Educação Infantil, aspecto que era costumeiramente negligenciado na época. A própria Educação Física estaria em convergência com a "pedagogia negativa", apreendida como respeito à disposição natural do infante.

Sobre a mencionada excelência ao cidadão, o autor recorre, mais uma vez, à história greco-romana para reforçar seu pensamento:

O mesmo espírito orientou todos os antigos legisladores; todos eles buscaram laços que unissem os cidadãos à pátria, assim como uns aos outros, encontrando esses vínculos em determinados costumes [...], em jogos que mantinham os cidadãos reunidos por muito tempo; em exercícios que, aumentando a sua força física, fortaleciam também o seu amor próprio e sua auto confiança [...].Os prêmios com que eram coroados os vencedores dos jogos, sob a aclamação de toda a Grécia, os motivavam permanentemente a enfrentar os 
desafios e buscar a glória, levando a sua coragem e suas virtudes a um tal grau de energia de que hoje não podemos fazer ideia, e que os modernos não chegam mesmo a considerar possível. (ROUSSEAU, 2003a, p. 228).

Esse olhar do filósofo, que se volta ao passado, é pensado por Albornoz (2006) como exame apurado da educação física não apenas no que diz respeito à saúde do corpo, mas como forma de prestigiar a moralidade, constituída no meio social e revitalizada por atividades físicas que contemplem estes elementos:

O cuidado com a educação corporal e a afirmação do seu valor para a educação da solidariedade e da cidadania pode ser interpretado como expressão do humanismo moderno, que emerge na renascença e cuja inspiração se encontra na antiguidade grecoromana, separando-se nisso dos séculos medievais, nos quais a fonte mais fortemente presente se associava no cristianismo à herança cultural de origem bíblica. Aí está expresso e claro que na educação física não se trata apenas da saúde do corpo, mas também de outros aspectos de ordem social ou moral, que pela educação do corpo podem ser atingidos. Por outro lado, essa crítica à modernidade coloca Rousseau entre os pensadores que olham para trás, para a origem, que na origem buscam a inspiração, tanto para a crítica dos seus contemporâneos como para as recomendações de mudança [...] (ALBORNOZ, 2006, p. 78).

Não obstante, no Capítulo XIII de Considerações, "Projeto para submeter todos os membros do governo a um progresso gradual", o filósofo ilustra como a educação pensada por ele, educação, esta, voltada à pátria e ao cumprimento da constituição, poderia continuar a manter no coração dos jovens e recentes cidadãos, pelo serviço público, a virtude pública:

\begin{abstract}
A justiça dá conteúdo à atividade na função pública e também repercute no sistema de ensino. Por outro lado, na educação moral, no cultivo da honestidade e o ensino da virtude está a garantia e o fundamento da justiça e do direito. (ALBORNOZ, 2006, p.83).
\end{abstract}

Antes mesmo de iniciar a primeira das etapas do serviço público, seria aberto aos jovens um tempo de experiência de pelo menos três anos nas diferentes repartições a serviço da pátria, como na companhia de "advogados, assessores, e até mesmo os juízes de tribunais inferiores, os controladores de recursos públicos e, de modo geral, em todos os postos inferiores" que constituíssem ambiente de 
enobrecimento intelectual e moral, já que, com reservas, desde que tal período se passasse com funcionários que pudessem "demonstrar o seu mérito, a sua capacidade, a sua correção, e sobretudo a sua integridade”. (ROUSSEAU, 2003a, p. 294). Ao final dessa experiência, o jovem receberia um certificado de seus superiores e um conceito público, com os quais se apresentaria à assembleia local à qual pertence. Nela, seria avaliado por sua conduta e, sendo a avaliação positiva, receberia uma placa de ouro com a inscrição de seu nome, da data e da expressão Spes Patriae, significando "A esperança da pátria". Os jovens que assim procedessem seriam intitulados "Servidores do Estado". Para destacar a importância deste título basta dizer, que para a proposta de Rousseau, não se poderia tornar um deputado ou ocupar qualquer cargo nas repartições públicas sem ter se tornado antes, um servidor do Estado.

Para alcançar a segunda etapa, seria preciso ter cumprido três mandatos como Deputado, cada um deles com aprovação rigorosa da assembleia local. Após o cumprimento desses mandatos, o cidadão receberia uma placa de prata, com a inscrição Civis Electus, "Cidadão Eleito", e assim estaria apto a candidatar-se ao Senado. Sem se esquecer do seu cuidado com as questões relativas à educação, o genebrino ressalta: "Minha inclinação seria escolher os diretores de colégios e inspetores de educação entre os que tivessem atingido a segunda etapa" (ROUSSEAU, 2003a, p. 295). Esse proposto caminho parece estar em sinergia com o raciocínio de Albornoz, pautado nas questões de educação, trabalho e patriotismo em Rousseau:

A educação popular, pensada como nacionalizante (ou socializante), que tem por primeira meta inserir profundamente o indivíduo em sua cultura, nas tradições e nas leis de seu povo, tem em vista, pois, sua inserção no mundo da economia e do trabalho, que dá corpo à vida social [...]. (2006, p. 77).

O genebrino afirma ser conveniente a criação de um Colégio de Magistrados que se responsabilize pela coordenação do sistema de educação, e que tenha, por exemplo, o poder de nomear e retirar do cargo diretores dos colégios e os encarregados pelas atividades físicas.

Concluindo o capítulo sobre a educação, o genebrino reforça sua preocupação com a constituição do zelo patriótico nas crianças e jovens, recuperando a função das instituições pertinentes de a ativarem e desenvolverem no 
coração dos homens: "Sem essas precauções, porém, nada se deve esperar das suas leis. Por mais sábias que sejam, por melhor que prevejam o futuro, serão vãs [...]". (ROUSSEAU, 2003a, p. 241). Boto destaca a amplitude da educação nacional para o pensamento do genebrino nessa obra, percebendo-a como "alicerce de uma existência coletiva bem fundada, disciplinada pela trama da lei [...]. Para Rousseau, como indica a autora, "Homens virtuosos são frutos da formação que tiveram na infância e na juventude. Gostos e opiniões formam-se e criam-se, pela prática da virtude" ${ }^{\text {. }}$. Esta virtude é a virtude da cidadania, pilar para a promoção das democracias. Boto ratifica, adicionalmente, a concepção do genebrino a respeito do sistema de ensino por ele organizado como "exemplo autêntico de educação virtuosa"86, processo que poderia ser entendido como um "segundo nascimento" advindo do "zelo patriótico" (expressões presentes em Considerações). 


\section{CONSIDERAÇÕES FINAIS}

$\mathrm{Na}$ presente dissertação, procuramos percorrer um caminho teórico cujas partes têm como função, agregar alguns textos, análises e reflexões que tornem possível o cumprimento de três objetivos principais: averiguar o uso das fontes greco-romanas em algumas das principais obras de Rousseau; tentar compreender os motivos que o levam a utilizar tão frequentemente esse recurso; estabelecer relações com a Educação, de modo a promover um melhor entendimento de sua visão político-educacional e de sua crítica social.

Em sua breve biografia, vimos que, desde criança, Rousseau teve a oportunidade de acessar, inicialmente por meio de Vidas Paralelas, de Plutarco, notórios exemplos da Antiguidade Clássica, fator que representou um referencial teórico que o genebrino jamais negligenciou no desenvolvimento de sua filosofia.

A partir do legado deixado pelas fontes greco-romanas, procuramos adentrar nos princípios republicanos delas advindos e, posteriormente, apropriados por Rousseau, ramificados tanto em suas obras como no Contrato Social, Considerações e Emílio, dentre outras, como a partir do enaltecimento do genebrino a algumas das principais características político-educacionais da Esparta clássica e Roma republicana. Tais princípios, como procuramos destacar, pautam-se nas ideias de identidade nacional e virtude cívica.

A abstração do genebrino a respeito do homem em seu estado de natureza, pode ser observada como outro recurso, para além do uso dos referenciais clássicos, de crítica às sociedades modernas, atentando para a corrupção social e o desvirtuamento do homem que, ao longo da história, cria artifícios que passam a tornar-se necessidades que o aprisionam. Buscamos destacar como a ideia de natureza humana para Rousseau e sua percepção a respeito da época em que vivia promoveu a escrita do Contrato social, no qual o homem, sentindo-se frágil em dado momento, com sua sobrevivência em risco, torna-se membro de uma comunidade, deixando sua condição natural para tornar-se membro do corpo civil, o qual seria responsável pela manutenção da vida do todo e de cada um.

A primeira parte deste trabalho teve como objetivo possibilitar um maior entendimento dos cenários governamentais de Esparta clássica e Roma republicana, percorrendo alguns recortes históricos desses referencias clássicos, de 
modo a caracterizá-los e promover o entendimento do uso próprio que o filósofo faz deles: sua meta não é reproduzir as repúblicas dos antigos, mas mostrá-las como estratégia para colocar em evidência questões voltadas ao bem comum e à formação para a cidadania, tão distantes do cenário político e educacional de sua época, de modo a fundamentar seus ideais político-pedagógicos. Rousseau assimilou-as como cidades-modelo pela vida política e comunitária que cultivavam, formando crianças e jovens para a manutenção do bem público e do legado deixado pelos mais velhos.

Em Esparta, o filósofo admirava o vínculo estabelecido entre os espartanos de cunho praticamente religioso, conferindo à Lacedemônia uma unidade política que o fascinava. A partir dos espartanos, Rousseau apropria-se da figura do sage, detentor do saber prático sustentado por uma postura virtuosa e ativa, que fomentava o bem público: o genebrino valorizava essa personalidade patriótica, tantas vezes ilustrada por traços aguerridos. Pudemos perceber como não bastava ter recebido a agogê, a educação da polis espartana e formação cívico-militar que engendrava o hoplita, soldado, para formar-se. Além disso, observamos a república como um todo formativo: o legado cultural, eventos públicos e cívicos, a vida política ativa, o exemplo dos mais velhos, dentre outros elementos, constituíam alicerces de formação para o espartano. Os gerontes, anciãos nomeados pelos cidadãos, por exemplo, representavam uma percepção de vida espartana em torno da consideração pública atribuída à honra. Constituíam o ideal de doação à cidadeestado e inspiravam os mais jovens. A virtude, nesse contexto, não advinha do indivíduo, mas da própria polis em seus ensinamentos e regras de conduta.

Nesse contexto, a liberdade só pode ser cívica e vivida sob o prisma do cidadão. Seria preciso aprender a viver essa categoria de liberdade. As syssitia, grupo de refeições comuns, ilustram outra vertente formativa de Esparta, nas quais os mais jovens, mesmo antes da efetiva integração a esses momentos, podiam participar com o intuito de se beneficiarem dos relatos exemplares de vida dos mais velhos. A imagem de Licurgo, revestida por uma aura divinizada, junto à sua legislação, e o impacto da tradição oral na formação dos espartanos, encaminhavam os membros da comunidade a uma libertação do eu pessoal - com paralelo possível ao processo de desnaturação tratado por Rousseau - para pertencerem 
inteiramente à pátria ${ }^{87}$. Os caminhos de formação da Esparta clássica engendravam, no hoplita, o desejo de alcançar a perfeição por meio da imortalidade da sua memória no seio da comunidade pela qual viveu ou morreu.

$\mathrm{Na}$ Roma republicana, como corrobora Leduc-Fayette (1974, p. 113), a frugalidade e a sobriedade de costumes conferiam à Roma outro traço característico atrelado à virtude política. Adicionalmente, a autora enfatiza o valor que Rousseau atribuía à austeridade e rusticidade dos tempos áureos republicanos, no qual os habitantes se consagravam aos trabalhos da terra, em uma existência próxima do estado de natureza. A respeito das virtudes campesinas, Marrou (1990, p. 369) aponta para a criança romana, incentivada a cultivar o amor ao trabalho árduo e à austeridade, ouvindo o respeito com que se falava a respeito do desprendimento dos velhos cônsules, que cultivavam a terra com as próprias mãos. Por meio dos bons hábitos e costumes, ensinados pela tradição e pelas instituições, o regime republicano poderia possibilitar a sua harmonia e manutenção, cultivando a virtude cívica. Essa virtude representa o ideal coletivo de consagração do indivíduo ao Estado: aqui vemos como Rousseau apropria-se desses traços romanos como exemplos edificantes da prioridade concedida aos princípios do bem coletivo, como no caso da singular atuação do tribunato, na proteção do povo soberano, colocandose contra qualquer forma de despotismo. Como vimos, diferentemente de Esparta, no entanto, aqui não observamos uma proposta de educação pública, uma vez que a educação era confiada às famílias: o lar era, para a república, a escola da cidadania, onde os primeiros ensinamentos eram promovidos. Apesar de, nesse recorte histórico, não haver uma proposta estatal, no que diz respeito à Educação, encontramos, na Roma republicana, outro propício ambiente formativo que fomentava, nas crianças e jovens, o amor à pátria, respeito ao legado cultural existente e postura cidadã ativa na manutenção dos direitos conquistados e da liberdade.

No momento que precisaram conferir à formação intelectual um novo perfil, o fizeram tendo em vista sua utilidade prática, o que caracterizava sua mentalidade pragmática: a educação deveria preparar para a vida. Outro traço formativo paralelo à influência dos gerontes de Esparta, reside no exemplo maiorum de Roma, o modelo dos mais velhos que se destacavam por uma postura virtuosa nas esferas

87 JAEGER, 2001, p. 113. 
familiar e política: "[...] os jovens tomavam contato com os mais velhos desde a mais tenra idade e, com isso, sua educação repousava no respeito ao 'costume ancestral', na tradição nacional e familiar". (SILVA, 2003, p. 155). Realizando-se na esfera do lar, a família, ativa no ensino da virtude cívica, era elemento-chave da sociedade romana, vista por Rousseau como um milagre que engendrava horror à tirania, promoção do patriotismo e da cidadania. A cerimônia de recebimento da toga civilis denota um evento simbólico e formativo para os romanos, representando o grau de reconhecimento que conferiam ao jovem romano no momento em que era visto como cidadão: marcada por um ritual no qual o adolescente despojava-se de uma túnica com uma franja colorida, toga pretexta, e dos símbolos que representavam a infância, envolvendo-se com outra totalmente branca, a toga civilis, com a qual apresentava-se no foro. Essa passagem incluía, adicionalmente, o tirocinium fori, a aprendizagem da vida pública. Aqui, mais uma vez vemos um recorte ilustrativo do valor que Rousseau atribuía às instituições no processo de desnaturação em prol da vida no seio de uma unidade comum e compartilhada. (ROUSSEAU, 2004, p. 1112). Leduc-Fayette (1974, p. 106) defendendo o mito romano como, primordialmente, um mito ético, afirma que, para o genebrino, assim como para Platão, Aristóteles e Montesquieu, ética e política não se dissociam no direito. Dessa forma, o exemplo romano demonstraria a possibilidade da união entre ética e política, tão caras ao filósofo, que não reconhecia essa síntese nas sociedades do século XVIII.

Rousseau e o Republicanismo, segunda parte desta dissertação, foi desenvolvida visando uma rápida retomada do contexto revolucionário do século XVIII francês, destacando o léxico republicano que foi, paulatinamente, construído em período anterior a esse contexto, constituindo respaldo teórico para os intelectuais da "época das Luzes". Procurou-se, assim, explicitar como esse léxico chegou até Rousseau, com suas vertentes de um apelo notoriamente voltado aos valores antigos. Bignotto (2010), partindo de sua hipótese inicial que, para compreender um governo republicano, seria necessário compreender a virtude, destaca como a virtude republicana sustentar-se-ia no amor pelas leis e pela pátria, abarcando a supremacia do bem comum. Observamos que, para Rousseau, tal como exemplificado nas Considerações, em parte posterior deste estudo, aprendese a amar a pátria, seja na vida em comunidade, seja por meio da educação pública. Bignotto destaca que o movimento teórico de retorno ao passado com o intuito de 
identificar referências de temas republicanos remonta ao Renascimento, onde o retorno à Antiguidade representava uma estratégia de questionamento à tirania e à exaltação de formas livres de governo. É nesse sentido que os regimes de Esparta e Roma representavam contrapontos utilizados, anteriormente, por Cícero e Tito Lívio, por exemplo. Explicitou-se como as referências históricas com "filtro" republicano não limitaram Rousseau a uma posição idealista, porque o mesmo já manifestava suas dúvidas a respeito da realização de formas de governos capazes de promover o bem público e a formação para a cidadania.

A nosso ver, tal como entende Bignotto (2010, p. 88), o elogio da conduta moral de Esparta e Roma, em Rousseau, visto como precursor dos totalitarismos contemporâneos - observado como uma simples transposição e correção histórica dos costumes corrompidos do século XVIII - representa uma incompreensão do legado rousseauniano. Parece-nos que a chave para o entendimento desse recurso está em investigar como as referências à Esparta e Roma - e sua apropriação pelo filósofo - relacionam-se a outros elementos essenciais de seu pensamento, como partes da construção de seu ideário republicano. Constitui-se em uma inspiração e em uma estratégia para reforçar suas principais ideias e para demarcar a Antiguidade em seu pensamento: destacamos a virtude cívica delineada a partir da vida ativa do cidadão que fomenta a república e é educado para a sua promoção, tal como o convite ao leitor a refletir sobre o relacionamento do cidadão com as questões do Estado e com suas instituições políticas.

A Enciclopédia francesa é, aqui, comentada como ferramenta concreta de críticas ao Antigo Regime, e respaldo teórico ao novo cenário político que despontava. Outra iniciativa de cunho intelectual e revolucionário, apresentada nessa parte, o jornal Bouche de fer, mostra-se, no contexto pós-revolução, frente ao legado de Rousseau, colocando-se como porta voz do povo oprimido e guia conceitual da população. Segundo Nascimento (2016b, p. 110-111), a leitura que os membros do Círculo Social, responsáveis pelo jornal, fazem do filósofo, exemplificam uma apropriação otimista da possibilidade de uma conquista plena da liberdade, onde a revolução configura-se como ocasião de regeneração não apenas para o povo francês, mas para todos os povos do mundo. Os membros do Círculo Social, que viam em Rousseau uma das pessoas excepcionais elencadas pela providência como instrumento de realização desse grande evento histórico, procuravam, em sua obra, fundamentos teórico-políticos para o amadurecimento 
desse grande movimento revolucionário.

Ao apresentarmos a abordagem desses intelectuais, inspirados no Contrato social, objetivamos destacar assimilações profícuas das possibilidades de ação advindas da teoria rousseauniana que, apesar de seu cunho realista diante das limitações das sociedades modernas, abre caminhos para se pensar novas vias de legitimação da vontade geral. O próprio Círculo representava uma iniciativa de caráter formativo: junto ao povo, mesmo considerando a especificidade da empreitada, traçavam-se novas metas para a qualificação de uma vida política embasada nos princípios republicanos.

A terceira parte, Formação para a cidadania, teve como meta promover vinculações no trâmite da transição do homem natural ao ser social como "concerto" possível na vida em comunidade. Adentrando em uma reflexão embasada no Emílio, procurou-se pensar essa obra como um texto rousseauniano que nos traz elementos de fundamental importância para se refletir sobre a formação para a cidadania, assunto que não é ignorado ou negligenciado pelo autor ao escrever esse tratado de Educação. Carlota Boto (2017, p. 266), destaca como o aperfeiçoamento, proveniente do sentimento de piedade natural, traz aproximações da infância ao homem em seu estado de natureza, demarcando a "liberdade bem regrada". Adicionalmente, Kawauche (2012, p. 36) permite associações teóricas ao resgatar a ideia de "alma expansiva" para representar a capacidade humana de identificação com seus pares, sendo esta capacidade desdobramento do amor de si a um amor dirigido a outros homens. Vimos, também, no artigo Rousseau e a questão das educações pública e doméstica ${ }^{88}$, outro respaldo teórico para a compreensão de que o filósofo, no Emílio, não deixa de lado a formação do cidadão e, por esse motivo, não opta exclusivamente pela formação do homem. Há, de fato, uma contradição homem-cidadão, ao passo que é vislumbrada pelo filósofo a possibilidade de uma conciliação ou "concerto" desse paradoxo. De modo a viabilizar essa contradição - e destacando a necessidade enfatizada por Rousseau de que o homem esteja de "acordo consigo mesmo", para alcançar a felicidade - o homem precisaria conciliar o cuidado de si e o cuidado com seus pares, na república.

No Emílio, como reforça Francisco, dadas a inexistência, na sociedade contemporânea a Rousseau, de instituição pública e pátria, decide-se formar o

88 FRANCISCO, 2010. 
homem natural. Tal formação é seguida, no entanto, concluída essa formação, pelo ser social. Consideramos, na presente dissertação, que as disposições naturais do homem quais sejam, amor de si e piedade natural, conduzem-nos ao entendimento de que a república é, na verdade, uma contínua formação e um contínuo exercício do bem público, do bem de cada membro do corpo social, consequentemente. $O$ bem público pode ser interpretado, a partir dessas pré-disposições naturais, como alicerce firmado no amor de si e na piedade natural. Aceitar o contrato jurídico rousseauniano é uma escolha racional e, também, pautada nos sentimentos naturais, na preservação de si e no bem querer do próximo, concidadão e parte da pátria.

Nos dois últimos capítulos de Educação para a cidadania, procuramos clarificar para o leitor os pontos que nos remetem a uma leitura de Considerações sobre o governo da Polônia como uma composição representativa da leitura de Rousseau de República e Educação, pensada simbolicamente pelo autor, na qual o genebrino resgata os referenciais antigos como recurso para ilustrar e reforçar sua Filosofia. Nessa obra, vislumbram-se instituições projetadas por Rousseau para a promoção do cidadão, com nítidos traços de suas raízes clássicas. Para nós, essas instituições podem ser entendidas como instituições formativas, as quais fomentavam a formação da alma nacional.

A nosso ver, nas cidades-modelo de Rousseau, todo o ambiente semeava a formação do almejado cidadão: não se tratava de uma proposta específica de educação aqui ou acolá, mas de uma arquitetura política a partir da qual crianças e jovens eram engendrados no seio de sua pátria a constituírem-se cidadãos na e pela vida em comunidade. Em Considerações observamos, seja na caracterização das instituições públicas, na estruturação do ensino público ou no delineamento da carreira pública e política, esse exato cuidado na engenharia de uma nação capaz de promover a formação para a cidadania. Nos escritos rousseaunianos, é possível acompanhar a importância formativa da república e, por isso, o retorno às fontes greco-romanas constituiu um objetivo, vinculado à função indispensável da figura dos governantes e educadores na medida em que se atribui à figura dos mais velhos e à tradição o papel de referenciais de lucidez histórica e respaldo educacional.

Como já ressaltamos, Bignotto (2010) afirma que a hipótese inicial de sua obra As aventuras da virtude baliza-se na ideia que, para compreender um governo republicano, é necessário compreender a virtude: a virtude republicana sustentada 
no amor pelas leis e pela pátria, abrangendo a supremacia do interesse público. Procuramos, no presente trabalho, evidenciar que, em Rousseau, há um engajamento teórico em se pensar como se educa uma criança ou jovem para amar sua pátria e reverenciar o bem comum. Com base nessa assertiva, esse parece ser um dos lugares das fontes greco-romanas no pensamento político-pedagógico do filósofo. Em Considerações, a título de exemplo, tendo em vista uma das vertentes que entendemos como formativa, eventos ou cerimoniais civis, observamos aproximações entre o momento máximo para o romano em formação. $O$ recebimento da toga civilis seguido pelo tirocinium fori, a aprendizagem da vida pública, e o programa pensado para o jovem polonês, que, ao final do primeiro estágio de experiência nas repartições públicas, poderia receber, de acordo com seu desempenho a serviço dos demais, uma placa de ouro com a expressão Spes Patriae, significando "A esperança da pátria".

Procuramos, nestas considerações finais, revisitar um pouco do caminho teórico percorrido nesta dissertação, de modo a promover uma análise dialógica entre as partes dessa composição para ressaltar o que aqui verificamos como uma genuína adesão de Rousseau aos exemplos da Antiguidade, aos quais o filósofo apropriou-se, dentre outros motivos, para destacar o que considera essencial: entendemos, neste trabalho, o âmbito político-formativo da república como imprescindível para a teoria rousseauniana. Parece-nos que uma república, para Rousseau, só é possível quando é essencialmente formativa, desenvolvendo com a Educação uma relação basilar e simbiótica.

Espera-se que a escrita do presente trabalho tenha contribuído para a compreensão do lugar das fontes greco-romanas nos escritos de Rousseau, ajudando a clarificar a leitura do autor de República e Educação, somando forças junto ao arcabouço teórico já existente sobre a temática e possibilitando novos entendimentos e vertentes de pesquisa.

Como sugestão para pesquisas futuras indica-se - tendo em vista o princípio contratualista que funda a obrigação política moderna e os aspectos essenciais das constituições ocidentais conhecidas e que deixa-nos hoje, questionamentos acerca do seu real cumprimento e legitimidade - investigar as possibilidades ou alternativas existentes de uma paulatina reestruturação dos princípios republicanos na atualidade, e quais caminhos teóricos Rousseau insinua em suas obras para tal empreitada, considerando o desvirtuamento das instituições públicas. 


\section{REFERÊNCIAS}

ALBORNOZ, S. G. Educação e trabalho nas Considerações sobre o governo da Polônia de Jean-Jacques Rousseau. In: Cadernos de Psicologia Social do Trabalho, v. 9, n. 2, p. 7387, São Paulo: Instituto de Psicologia/USP, 2006.

ALVES, V. F. C. Jean-Jacques Rousseau e o perigo da corrupção política na República. 2017. 312 f. Tese (Doutorado em Filosofia) - Faculdade de Filosofia Universidade Federal de Goiás, Goiânia, 2017.

AMES, J. L. Maquiavel e a educação: a formação do bom cidadão. Trans/Form/Ação, São Paulo, v. 31, n. 2, p. 137-152, 2008.

ARAGÃO, J. M. Desnaturação em Rousseau: corrupção ou aperfeiçoamento? 2008. 95 f. Dissertação (Mestrado em Filosofia) - Faculdade de Filosofia e Ciências Humanas Universidade Federal da Bahia, Salvador, 2008.

ASSUMPÇÃO, L. F. B. O processo de formação do jovem em Esparta, no século V a. C.: A relevância político-social da agôgé. Anais da Jornada de Estudos Antigos e Medievais da Universidade Estadual de Maringá, set. 2011, HUMA Multimídia - Mari \& Lene Digitações Ltda., 2011. v. 1. p. 01-15.

BARROS, G. N. M. de. Platão, Rousseau e o Estado Total. São Paulo: T. A. Queiroz, 1995.

BECKER, E. Política e linguagem em Rousseau. Tese (Doutorado em Filosofia). São Paulo, 2008. 267 f. Faculdade de Filosofia, Letras e Ciências Humanas - Universidade de São Paulo.

BIGNOTTO, N. As aventuras da virtude: as ideias republicanas na França do século XVIII. São Paulo: Companhia das Letras, 2010.

BORGES JR., C. L. Verdade e virtude: os fundamentos da moral no Discurso sobre as Ciências e as Artes de J.-J. Rousseau. 2015. 135 f. Dissertação (Mestrado em Filosofia) Faculdade de Filosofia, Letras e Ciências Humanas - Universidade de São Paulo, São Paulo, 2015.

BOTO, C. Instrução pública e projeto civilizador: o século XVIII como intérprete da ciência, da infância e da escola. São Paulo: Editora UNESP, 2017.

CEREZUELA, J. de Ba. Jean-Jacques Rousseau e o Republicanismo: ideal de participação política dos cidadãos no modelo rousseauniano de república. 2006. $122 \mathrm{f}$. Dissertação (Mestrado em Ciências Sociais) - Centro de Letras e Ciências Humanas Universidade Estadual de Londrina, Londrina, 2006.

CHAUÍ, M. Prefácio. In: NASCIMENTO, Milton Meira. Opinião Pública e Revolução. São Paulo: Discurso Editorial, 2016.

CíCERO, M. T. Da República. São Paulo: Cultvox, 2001.

Disponível em:

<http://www.dominiopublico.gov.br/pesquisa/DetalheObraForm.do?select_action=\&co_obra= 2>247. Acesso em: 15 set. 2016. 
DENT, N. J. H. Dicionário Rousseau. Rio de Janeiro: Jorge. Zahar, 1996.

FERREIRA, J. R. Grécia e Roma na Revolução Francesa. Revista de História das Ideias, v. 10, p. 203-234. Coimbra, 1988.

FONSECA JR., G (Org.). Rousseau e as relações internacionais. São Paulo: Imprensa Oficial do Estado, 2003.

FRANCISCO, M. de F. S. Autoridade e contrato pedagógico em Rousseau. In: AQUINO, J. G. (Org.). Autoridade e autonomia na escola: alternativas teóricas e práticas. 2. ed. São Paulo: Summus Editorial, 1999.

. Notas acerca da Educação Doméstica e Educação Pública no Emílio de Rousseau. Notandum Libro, v. 16, São Paulo/ Porto, p. 59-78, 2008.

Rousseau e a questão das educações pública e doméstica. Cadernos de Ética e Filosofia Política, n. 16, p. 59-78, São Paulo, jan. 2010.

JAEGER, W. Paidéia: a Formação do Homem Grego. São Paulo: Martins Fontes, 2001.

KAWAUCHE, T. Religião e Política em Rousseau. 2012. 208 f. Tese (Doutorado em Filosofia) - Faculdade de Filosofia, Letras e Ciências Humanas - Universidade de São Paulo, São Paulo, 2012.

LEDUC-FAYETTE, D. J.-J. Rousseau et le mythe de l'antiquité. Paris: VRIN, 1974.

MANSUY, D. Comercio y virtude em el pensamento de Montesquieu. Ideas y Valores. v. 65, n. 162, p. 213-232, Bogotá, dez. 2016

MAQUIAVEL, N. Discursos sobre a primeira década de Tito Lívio. Brasília: UnB, 1994.

MARROU, H.-I. História da Educação na Antiguidade. 5 ed. São Paulo: EPU, 1990.

MCKENZIE, L. A. Rousseau's debate with Machiavelli in the Social Contract. Journal of the History of Ideas, v. 43, n. 2, p. 209-228, abr./jun. 1982.

MELO, J. J. P. A educação e o Estado Romano. Periódicos UDESC, Florianópolis, v. 7, n. 2, p. 1-19, 2007.

MOSCATELI, R. Rousseau e Maquiavel, pensadores republicanos. Cadernos de Pesquisa, v. 22, n. especial, p. 43-57, São Luís, 2015.

Rousseau frente ao legado de Montesquieu: Imaginação histórica e teorização política. 2009. 339 f. Tese (Doutorado em Filosofia) - Instituto de Filosofia e Ciências Humanas - Universidade Estadual de Campinas, Campinas, 2009.

NASCIMENTO, M. M. do. A farsa da representação política: ensaios sobre o pensamento político de Rousseau. São Paulo: Discurso Editorial, 2016a.

Opinião pública e revolução. São Paulo: Discurso Editorial, 2016b.

ROUSSEAU, J.-J. Considerações Sobre o Governo da Polônia e a sua projetada Reforma. In: FONSECA JR., G (Org.). Rousseau e as relações internacionais. São Paulo: Imprensa Oficial do Estado, 2003a. 
Discurso sobre economia política e Do contrato social. Tradução de Maria Constança Peres Pissarra. Petrópolis: Vozes, 1996. (Clássicos do pensamento político; 15).

Do Contrato Social. Tradução de Lourdes Santos Machado. Introduções e notas de Paul Arbousse-Bastide e Lourival Gomes Machado. São Paulo: 2ª edição, abril, 1978. (Coleção Os Pensadores)

O Estado de Guerra Nascido do Estado Social. In: FONSECA JR., G (Org.). Rousseau e as relações internacionais. São Paulo: Imprensa Oficial do Estado, 2003b.

Sobre o Contrato Social. In: FONSECA JR., G (Org.). Rousseau e as relações internacionais. São Paulo: Imprensa Oficial do Estado, 2003c.

Tratado sobre Economia Política. In: FONSECA JR., G (Org.). Rousseau e as

relações internacionais. São Paulo: Imprensa Oficial do Estado, 2003d.

Discurso sobre a economia política. Petrópolis: Editora Vozes, 1996.

Discurso sobre a origem e os fundamentos da desigualdade entre os homens. Porto Alegre: Editora L\&PM, 2008.

Emilio ou da Educação. São Paulo: Martins Fontes, 2004.

SALINAS FORTES, L. R. Fazer o homem ou o cidadão? Revista Perspectiva, Florianópolis, v. 6, n. 11, p. 9-12, jul/dez. 1988.

Rousseau: o bom selvagem. São Paulo: FTD, 1989.

SILVA, F. de B. Jean-Jacques Rousseau: a face arcaica do cidadão. 2000. 192 f. Dissertação (Mestrado em Educação) - Faculdade de Educação, Universidade de São Paulo, São Paulo, 2000.

SILVA, G. L. R.; ZANARDINI, J. B. Uma leitura de Jean-Jacques Rousseau: Considerações preliminares sobre Emílio ou da Educação. Revista HISTEDBR, Campinas, v. 12, n. 12, dez/2003.

SILVA, R. A. V. Os ideais de igualdade, fraternidade e liberdade na prática democrática: entre Rousseau e Habermas. Revista Lumen et Virtus, São Paulo, v. 2, n. 4, p. 121-133, maio/2011.

SOUZA, M. das G. de. Ilustração e história: o pensamento sobre a história do lluminismo francês. São Paulo: Discurso editorial, 2001.

VEIGA, G. O significado sagrado do esporte e do jogo. In: ALMEIDA, L. G. V.; DANTAS, J. M. B. R.; PEREIRA, O. A Margem - Coletânea de textos na margem da Filosofia. Brasília: Thesaurus, 1999. 